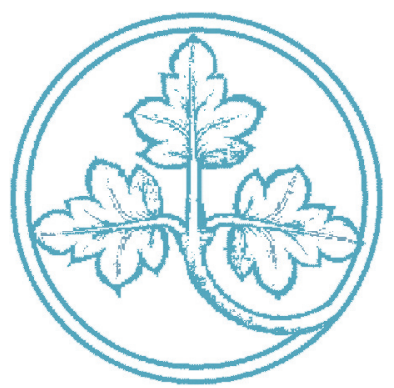

Fallacies, Irrelevant Facts, and Myths in the Discussion of Capital Regulation: Why Bank Equity is Not Expensive

Anat R. Admati

Peter M. DeMarzo Martin F. Hellwig Paul Pfleiderer

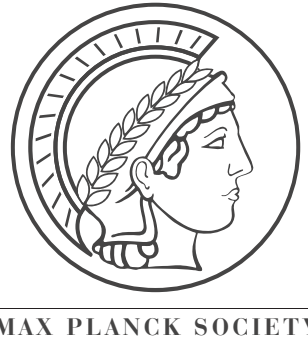




\title{
Fallacies, Irrelevant Facts, and Myths in the Discussion of Capital Regulation: Why Bank Equity is Not Expensive
}

\author{
Anat R. Admati \\ Peter M. DeMarzo \\ Martin F. Hellwig \\ Paul Pfleiderer*
}

First Draft August 27, 2010

This draft March 23, 2011

\begin{abstract}
*Admati, DeMarzo and Pfleiderer are from the Graduate School of Business, Stanford University; Hellwig is from the Max Planck Institute for Research on Collective Goods, Bonn. We are grateful to Viral Acharya, Tobias Adrian, Jürg Blum, Patrick Bolton, Arnoud Boot, Michael Boskin, Christina Büchmann, Darrell Duffie, Bob Hall, Bengt Holmström, Christoph Engel, Charles Goodhart, Andy Haldane, Hanjo Hamann, Ed Kane, Arthur Korteweg, Ed Lazear, Hamid Mehran, David Miles, Stefan Nagel, Francisco Perez-Gonzales, Joe Rizzi, Steve Ross, Til Schuermann, Isabel Schnabel, Hyun Shin, Chester Spatt, Ilya Strebulaev, Anjan Thakor, Jean Tirole, Jim Van Horne, and Theo Vermaelen for useful discussions and comments. Contact information: admati@stanford.edu; demarzo_peter@gsb.stanford.edu; hellwig@coll.mpg.de; pfleider@stanford.edu.
\end{abstract}




\begin{abstract}
We examine the pervasive view that "equity is expensive," which leads to claims that high capital requirements are costly and would affect credit markets adversely. We find that arguments made to support this view are either fallacious, irrelevant, or very weak. For example, the return on equity contains a risk premium that must go down if banks have more equity. It is thus incorrect to assume that the required return on equity remains fixed as capital requirements increase. It is also incorrect to translate higher taxes paid by banks to a social cost. Policies that subsidize debt and indirectly penalize equity through taxes and implicit guarantees are distortive. Any desirable public subsidies to banks' activities should be given directly and not in ways that encourage leverage. And while debt's informational insensitivity may provide valuable liquidity, increased capital (and reduced leverage) can enhance this benefit. Finally, suggestions that high leverage serves a necessary disciplining role are based on inadequate theory lacking empirical support.
\end{abstract}

We conclude that bank equity is not socially expensive, and that high leverage is not necessary for banks to perform all their socially valuable functions, including lending, deposittaking and issuing money-like securities. To the contrary, better capitalized banks suffer fewer distortions in lending decisions and would perform better. The fact that banks choose high leverage does not imply that this is socially optimal, and, except for government subsidies and viewed from an ex ante perspective, high leverage may not even be privately optimal for banks.

Setting equity requirements significantly higher than the levels currently proposed would entail large social benefits and minimal, if any, social costs. Approaches based on equity dominate alternatives, including contingent capital. To achieve better capitalization quickly and efficiently and prevent disruption to lending, regulators must actively control equity payouts and issuance. If remaining challenges are addressed, capital regulation can be a powerful tool for enhancing the role of banks in the economy.

Keywords: capital regulation, financial institutions, capital structure, "too big to fail," systemic risk, bank equity, contingent capital, Basel, market discipline.

JEL classifications: G21, G28, G32, G38, H81, K23. 


\section{Table of Contents}

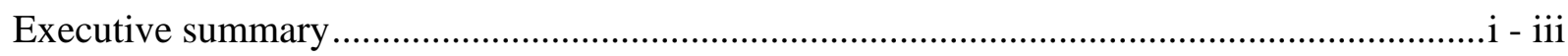

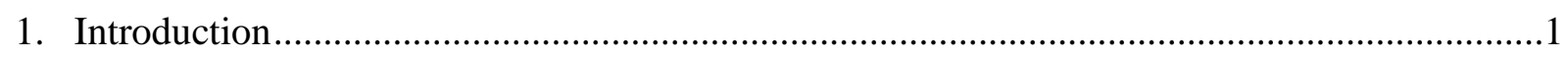

2. The Benefits of Increased Equity Capital Requirements ...................................................

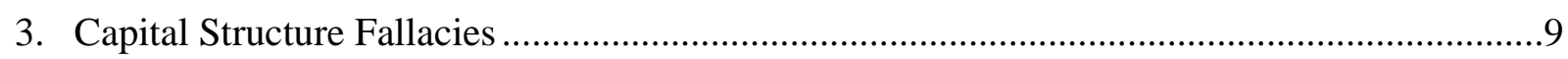

3.1. What is Capital and What are Capital Requirements?....................................................10

3.2. Equity Capital Requirements and Balance Sheet Mechanics ..........................................11

3.3. Equity Capital Requirements and the Return on Equity (ROE) .....................................14

3.4. Equity Capital Structure and the Cost of Capital.............................................................16

4. Arguments Based on Confusion of Private vs. Social Costs …...........................................19

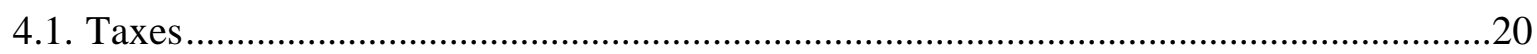

4.2. Bailouts and Implicit Government Guarantees..........................................................21

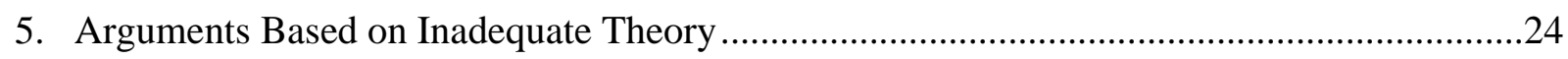

5.1. Leverage and the Informational Insensitivity of Debt...................................................25

5.2. Does Debt Provide Necessary Market Discipline?.........................................................27

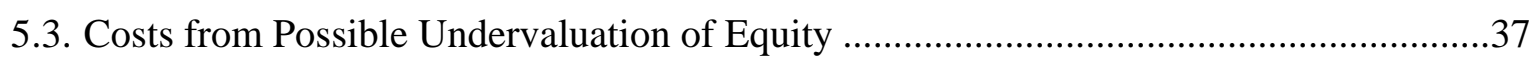

5.4. Is Observed High Leverage Evidence that Equity Requirements are Socially Costly? ...39

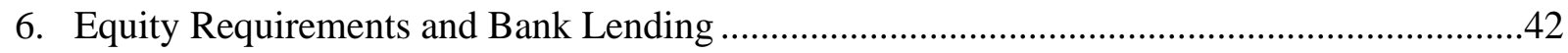

7. Increased Bank Equity, Informationally-Insensitive Debt, Asset Allocations and Liquidity..47

8. A Skeptical View of Contingent Capital and Bail-in Mechanisms ......................................53

9. Concluding Remarks and Policy Recommendations ..........................................................56

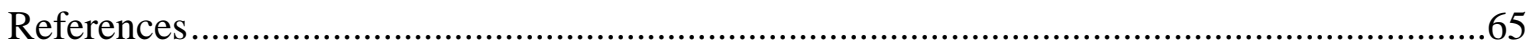




\section{Executive Summary}

There is a pervasive sense in discussions of bank capital regulation that "equity is expensive" and that higher equity requirements, while beneficial, also entail a significant cost. The arguments we examine, which represent those most often made in this context, are fallacious, irrelevant, or very weak. Our analysis leads us to conclude that requiring that banking institutions are funded with significantly more equity entails large social benefits and minimal, if any, social costs. We list below some of the arguments made against high equity requirements and explain why they are either incorrect or unsupported.

\section{Some common arguments made against significantly increasing equity requirements:}

- Increased equity requirements would force banks to "set aside" or "hold in reserve" funds that can otherwise be used for lending. This argument confuses capital requirements with liquidity or reserve requirements. Capital requirements refer to how banks are funded and in particular the mix between debt and equity on the balance sheet of the banks. There is no sense in which capital is "set aside." Liquidity or reserve requirements relate to the type of assets and asset mix banks must hold. Since they address different sides of the balance sheet, there is no immediate relation between liquidity requirements and capital requirements.

- Increased equity requirements would increase banks' funding costs because equity requires a higher return than debt. This argument is fallacious, because the required return on equity, which includes a risk premium, must decline when more equity is used. Any argument or analysis that holds fixed the required return on equity when evaluating changes in equity capital requirements is fundamentally flawed.

- Increased equity requirements would lower the banks' Return on Equity (ROE), and this means a loss in value. This argument is also fallacious. The expected ROE of a bank increases with leverage and would thus indeed decline if leverage is reduced. This change only compensates for the change in the risk borne by equity holders and does not mean that shareholder value is lost or gained, except possibly if increased leverage brings more government subsidies.

- Increased equity requirements would increase banks' funding costs because banks would not be able to borrow at the favorable rates created by tax shields and other subsidies. It is true that, through taxes and underpriced explicit or implicit guarantees, debt financing is subsidized and equity financing is effectively penalized. Policies that encourage high leverage are distorting and paradoxical, because high leverage is a source of systemic risk. The subsidies come from public funds. If some activities performed by banks are worthy of public support, subsidies should be given in ways that do not lead to excessive leverage.

- Increased equity requirements would be costly since debt is necessary for providing "market discipline" to bank managers. While there are theoretical models that show that debt can sometimes play a disciplining role, arguments against increasing equity requirements that are 
based on this notion are very weak. First, high leverage actually creates many frictions. In particular, it creates incentives for banks to take excessive risk. Any purported benefits produced by debt in disciplining managers must be measured against frictions created by debt. Second, the notion that debt plays a disciplining role is contradicted by the events of the last decade, which include both a dramatic increase in bank leverage (and risk) and the financial crisis itself. There is little or no evidence that banks' debt holders provided any significant discipline during this period. Third, many models that are designed to attribute to debt a positive disciplining role completely ignore the potential disciplining role that can be played by equity or through alternative governance mechanisms. Fourth, the supposed discipline provided by debt generally relies upon a fragile capital structure funded by short term debt that must be frequently renewed. Whereas capital regulation is intended to reduce fragility, fragility is a necessary by-product of the purported disciplining mechanism. Finally, one must ask if there are no less costly ways to solve governance problems.

- Increased equity requirements would force or cause banks to cut back on lending and/or other socially valuable activities. First, higher equity capital requirements do not mechanically limit banks' activities, including lending, deposits taking and the issuance of liquid money-like, informationally-insensitive securities. Banks can maintain all their existing assets and liabilities and reduce leverage through equity issuance and the expansion of their balance sheets. To the extent that equity issuance improves the position of existing creditors and/or it may be interpreted as a negative signal on the bank's health, banks might privately prefer to pass up lending opportunities if they must fund them with equity. The "debt overhang" problem can be alleviated if regulators require undercapitalized banks to recapitalize quickly by restricting equity payouts and mandating new equity issuance. Once better capitalized, banks would make better lending and investment decisions and issuance costs would be reduced.

- The fact that banks tend to fund themselves primarily with debt and have high levels of leverage implies that this is the optimal way to fund bank activities. It does not follow that just because financial institutions choose high leverage, this form of financing is privately or socially optimal. Instead, this observed behavior is the result of factors unrelated to social concerns, such as tax incentives and other subsidies, and to frictions associated with conflicts of interests and inability to commit in advance to certain investment and financing decisions.

- High equity requirements will drive banking activities from regulated to unregulated sectors and would thus be ineffective or even harmful. First, in the run-up to the crisis, many activities and entities in the so-called "shadow banking system" relied on credit backstops and other commitments made by regulated entities. Thus, these activities and entities were, and continue to be, within regulators' reach. Second, defining on a continual basis the entities and activities that should be regulated will always be a challenge. It is far from clear that, given the tools already, and potentially, available to lawmakers and regulators, the challenge of effective capital regulation cannot be met. 


\section{Recommendations}

- Since, as we have argued, bank equity is not expensive, regulators should use equity requirements as a powerful, effective, and flexible tool with which to maintain the health and stability of the financial system. High leverage is not required in order for banks to perform all their socially valuable functions, such as providing credit and creating liquid securities. Not only does high leverage create fragility and systemic risk, it is in fact leads to distorted lending decisions.

- Regulators should use restrictions on equity payouts and mandate equity issuance to help banks, and to assure that they maintain adequate and high equity capitalization. If this presents a governance problem, such problems can be solved with the help of regulators. Prohibiting, for a period of time and for all banks, any dividends and other equity payouts, and possibly imposing equity issuance on a pre-specified schedule, is an efficient way to help banks build their equity capital quickly and efficiently without leading to the contraction of credit. If done under the force of regulation, withholding payouts or issuing additional equity would not lead to negative inferences about the health of any particular bank. It would also alleviate the debt overhang distortion that might lead banks to reduce lending.

- If certain activities of the banking sector are deemed to require subsidies, then subsidies should be given in ways that alleviate market frictions and not through a system that encourages high leverage. Tax shields and implicit government guarantees subsidize debt finance and thus create a wedge between the private incentives of the banks and social concerns. This policy is undesirable given the systemic risk and additional frictions brought about by high leverage.

- Better resolution procedures for distressed financial institutions, while necessary, should not be viewed as alternatives to having significantly better capitalized banks. Since such procedures are not likely to eliminate the cost of financial distress, reducing the likelihood that a resolution procedure is needed is clearly important, and higher equity requirements are the most effective way to do so.

- Higher equity requirements are superior to attempts to fund bailouts through a "bailout fund" supported by bank taxes. While charging banks upfront could potentially remove the subsidy associated with bailouts, failure to properly adjust the tax to the risk of individual banks could create significant distortions, particularly excessive risk taking. Equity requirements, as a form of self-insurance where the bank backs up its liabilities more directly, would be priced by financial markets and be more effective in reducing the need for government intervention.

- Approaches based on equity are superior to those that rely on non-equity securities such as long term debt or contingent capital to be considered part of capital regulation. Contingent capital, and related "bail-in" proposals, where debt is converted to equity when a trigger event occurs, are complicated to design and present many implementation issues. There is no compelling reason that the "debt-like" feature of contingent capital has social value. Simple approaches based on equity are more effective and would provide more reliable cushions. 


\section{Introduction}

As the financial crisis of 2007-2008 has compellingly shown, highly leveraged financial institutions create negative externalities. When a bank is highly leveraged, even a small decrease in asset value can lead to distress and potential insolvency. In a deeply interconnected financial system, this can cause the system to freeze, ultimately leading to severe repercussions for the rest of the economy. ${ }^{1}$ To minimize social damage, governments may feel compelled to spend large amounts on bailouts and recovery efforts. Even when insolvency is not an immediate problem, following a small decrease in asset values, highly-leveraged banks may be compelled to sell substantial amounts of assets in order to reduce their leverage; such sales can put strong pressure on asset markets and prices and, thereby, indirectly on other banks.

Avoidance of such "systemic risk" and the associated social costs is a major objective of financial regulation. Because market participants, acting in their own interests, tend to pay too little attention to systemic concerns, financial regulation and supervision are intended to step in and safeguard the functioning of the financial system. Given the experience of the recent crisis, it is natural to consider a requirement that banks have significantly less leverage, i.e., that they use relatively more equity funding so that inevitable variations in asset values do not lead to distress and insolvency.

A pervasive view that underlies most discussions of capital regulation is that "equity is expensive," and that equity requirements, while having substantial benefits in preventing crises, also impose costs on the financial system and possibly on the economy. Bankers have mounted a campaign against increasing equity requirements. Policy makers and regulators are particularly concerned by assertions that increased equity requirements would restrict bank lending and would impede economic growth. Possibly as a result of such pressure, the proposed Basel III requirements, while moving in the direction of increasing capital, still allow banks to remain very highly leveraged. ${ }^{2}$ We consider this very troubling, because, as we show below, the view that equity is expensive is flawed in the context of capital regulation.

We will examine various arguments that are made to support the notion that there are social costs, and not just benefits, associated with increased equity requirements. Our conclusion is that the social costs of significantly increasing equity requirements for large financial institutions

\footnotetext{
${ }^{1}$ Similar observations are made, for example, Adrian and Shin (2010) and Adrian and Brunnermeier (2010).

${ }^{2}$ The proposed requirements set minimal levels for Core Capital at $7 \%$ (including a $2.5 \%$ anti-cyclical buffer) and for Tier 1 Capital at $8.5 \%$ of "risk weighted" assets, up from $2.5 \%$ and $4 \%$, respectively. Tier 1 Capital includes certain kinds of subordinated debt with infinite maturities; Tier 2 Capital even includes certain kinds of debt with finite maturities. In assessing these numbers, one has to bear in mind that risk-weighted assets usually are a fraction of total assets, for some banks as low as one tenth - and that, in the crisis, some assets that had zero risk weights induced losses exceeding the bank's equity. The proposed "leverage ratio" regulation involves a requirement that equity must be at least $3 \%$ of un-weighted total assets.
} 
would be, if there were any at all, very small. All the arguments we have encountered that suggest otherwise are very weak when examined from first principles and in the context of optimal regulation. They are based either on fallacious claims, on a confusion between private costs to banks and social costs to the public, or on models that are inadequate from both a theoretical and an empirical perspective.

The discussion is often clouded by confusion between capital requirements and liquidity (or reserve) requirements. This confusion has resulted in routine references in the press to capital as something banks must "set aside" or "hold in reserve." Capital requirements refer to how banks are funded and in particular the mix between debt and equity on the balance sheet of the banks. There is no sense in which capital is "set aside." Liquidity or reserve requirements relate to the type of assets and asset mix banks must hold. Since they address different sides of the balance sheet, there is no immediate relation between liquidity or reserve requirements and capital requirements. However, if there is more equity and less debt on the balance sheet, liquidity concerns may not be as acute, because creditors have relatively fewer claims and the probability of insolvency is smaller; hence, a run by creditors is less of a problem to be concerned about. High equity can therefore alleviate concerns about liquidity. The discussion that follows is focused on capital, and, more specifically, equity requirements. ${ }^{3}$

We begin by showing that equity requirements need not interfere with any of the socially valuable activities of banks, including lending, deposit taking, or the creation of "money-like," liquid, and "informationally-insensitive" securities that might be useful in transactions. In fact, the ability to provide social value would generally be enhanced by increased equity requirements, because banks would be likely to make more economically appropriate decisions. Among other things, better capitalized banks are less inclined to make excessively risky investments that benefit shareholders and managers at the expense of debt holders or the government. In addition, the debt issued by better capitalized banks is safer and generally less "informationally sensitive" and thus potentially more useful in providing liquidity.

Despite the fact that equity, because it is riskier, has a higher required return than debt, the use of more equity funding need not change the overall funding cost of banks. Using more equity financing lowers the riskiness of a bank's equity (and perhaps also of its debt). Unless those who fund the bank are fooled so that securities are mispriced, simply shifting the way that risk is borne by different investors need not have any direct effects on the overall funding cost of the bank. $^{4}$

\footnotetext{
${ }^{3}$ As mentioned in fn. 2, regulatory capital includes some securities that are hybrid or even just subordinated debt. In this paper, we do not dwell on these differences. In our view, capital regulation should focus on equity.

${ }^{4}$ These observations constitute some of the most basic insights in corporate finance. Yet, numerous statements in the policy debate on this subject fail to take them into account and therefore are based on faulty logic. Thus, in many studies of the impact of increased equity requirements, including, for example, BIS (2010a), the required return on equity is taken to be a constant number; yet this required return must go down if banks have more equity. While the
} 
Various distortions and frictions in the economy do affect banks' cost of debt and equity finance. Some of the most important frictions and distortions are actually created by public policy. For example, most tax systems give an advantage to debt financing and penalize equity financing. Some of the arguments against higher equity capital requirements are based on the "costs" banks would incur if they had to give up some of this subsidized debt financing. From a public policy perspective these arguments are wrong since they inappropriately focus on private costs to the bank rather than social costs. Ideally, taxes should be structured to minimize the overall distortions they induce, which means that they should encourage behavior that generates positive externalities and discourage behavior that generates negative externalities. A tax system that encourages banks to take on socially costly excessive leverage is highly distortionary and dysfunctional. If the banking system needs to be subsidized, more effective and less costly ways must be found to do that. Taking the tax code as given is inappropriate in this context; all relevant aspects of public policy should be considered.

Implicit government guarantees, as well as underpriced explicit guarantees, constitute another distortion that favors debt over equity financing for many financial institutions. A subsidized "safety net" involves the danger of the "privatization of profits and socialization of costs." Banks benefit from it by being able to borrow more cheaply than they otherwise would. Although politicians are fond of saying that bailouts should never happen, it is impossible, and not even desirable, for governments to commit to never bail out a financial institution. It is true that fully charging banks for the guarantees would remove this subsidy, but it is extremely difficult for the government to do this, and incentives to take excessive risk remain a problem with any type of insurance plan. A more prudent approach is to require banks to have significantly less leverage, so as to lower the social cost associated with any implicit (or underpriced) guarantees and to minimize the likelihood of bank failure that would necessitate resolution or bailout. Again, if subsidizing banks is desirable, the government should find other, more direct ways, to do so without directly encouraging leverage.

Some have argued that higher equity capital requirements would be costly because debt plays a positive role in reducing frictions due to governance and asymmetric information. For example, it has been suggested that debt serves as a "disciplining device" to prevent managers from wasting or diverting funds. Short term debt, or long term debt when some of it needs to be renewed periodically, is said to provide "market discipline" because the fear that it might be withdrawn or not renewed leads managers to act more in line with the preferences of creditors, and even avoid taking excessive risk. Our assessment is that the theoretical and empirical foundations of these claims are very weak, and that the models that are used to support them are

fact that the required return would fall is mentioned in the text of BIS (2010a), the empirical analysis still assume a constant required return on equity, and this rate is also used inappropriately in other parts of the study. The study by IIF also suffers from such shortcomings. 
simply inadequate for guiding policy regarding capital requirements. Among other things, leverage in fact creates significant frictions and governance problems that distort the lending and investment decisions of financial institutions. These frictions are exacerbated in the presence of implicit guarantees, which also blunt any potential discipline of debt by removing the incentives of debt holders to engage in monitoring. Moreover, we argue that the events of the recent financial crisis are in fact quite difficult to reconcile with the notion that debt plays a positive role in providing ex ante discipline to bank managers. Finally, even if it debt can play a positive role in governance, we argue that in many cases additional equity would not interfere with this function, and also that debt is not uniquely able to provide discipline. We discuss a number of alternative ways to achieve the same results without resorting to socially costly leverage.

Another argument against higher equity capital requirements is based on the claim that equity is costly for banks to issue. Issuing equity can be costly if the banks shares are undervalued by the market or if the market interprets the decision to issue equity as a negative signal. We argue that these considerations are not valid reasons for not requiring banks to have significantly more equity. First, the negative signal that might be associated with the bank selling shares can be reduced or removed if banks have less discretion with respect to equity issuance. Similar to how large banks were all forced, or at least pressured, to accept TARP funds during the recent crisis, to help banks build capital, regulators can impose a time table for equity issuance so as to remove possible negative stigma associated with such issuance. Second, better capitalized banks need less external finance, as they have more retained earnings with which to fund their growth. Third, better capitalized banks incur proportionately lower costs when issuing additional equity. Finally, because higher equity goes along with a lower default risk, it also enhances the liquidity of debt securities issued by the bank. Higher equity need not interfere with the use of collateral in trading.

Since banks are actually highly leveraged, there is a temptation to conclude that such high leverage must be the optimal solution to some problem banks face. We argue that there is no justification for this inference. First, government subsidies give incentives to banks to use high levels of debt financing. In this regard, high leverage might be privately optimal for the banks, but this clearly does not make it socially optimal. Second, there are numerous reasons to conclude that high leverage is not even privately optimal for banks. ${ }^{5}$ High leverage can be the result of banks' inability to make commitments regarding future investments and financing decisions. Given continual incentives to increase leverage and shorten its maturity to usurp prior creditors, a bank's capital structure, as it evolves over time, is likely to have leverage that is excessive even from the narrow perspective of what is good for the bank and its shareholders (except, of course, for government subsidies of debt).

\footnotetext{
${ }^{5}$ Consistent with this, Mehran and Thakor (2010) find that various measures of bank value are positively correlated with bank capitalization in the cross section. Berger and Bouwman (2010) show that higher bank capital is important in banks’ ability to survive financial crises.
} 
How would significantly higher equity capital requirements affect the lending activities of banks? We argue that, since highly leveraged banks are subject to distortions in their lending decisions, better capitalized banks are likely to make better lending decisions, which are less subject to incentives for taking on risk or to problems related to "debt overhang" that can actually prevent banks from making valuable loans. There is indeed no reason for banks to refrain from any socially valuable activity, since these activities would not become more costly once any required subsidies are set at an appropriate level. Thus, there is no reason to believe that, if overall public policy forces banks to operate with significantly higher equity levels and significantly reduce their leverage, and if any subsidies are set in a socially responsible way, banks would refrain from making any loans that would lead to growth and prosperity. Highly leveraged banks might respond to increased capital requirements by restricting loans because of the "debt overhang" problem mentioned above, but this will be alleviated once banks are better capitalized. In the transition, regulators can forbid equity payouts and possibly mandate equity issuance to make sure this does not happen. Additional equity also enhances the bank's ability to provide money-like securities that investors may value, since such securities become even less risky and more "informationally insensitive” when they are backed by additional equity.

We show that adding equity to banks' balance sheets need not have any negative effect on the aggregate production activities or asset holdings in the economy. We also show that it need not interfere with the creation of creation of informationally-insensitive securities that are easy to liquidate. If additional equity is used by banks to buy marketable securities, this does not affect the undertaking of all productive activities in the economy or the portfolios of final investors. If the banks buy securities that are liquid, the liquidity of the bank's assets will be enhanced, which is a potential additional benefit.

We argue that the case for contingent capital and bail-in procedures, mechanisms that convert debt to equity under some conditions, has not been made against alternatives such as increased equity. Contingent capital is very complicated in terms of its design and valuation. Bail in mechanisms place extraordinary demands on regulators in crisis situations and present many implementation issues. We do not see a compelling rationale for introducing either of these as part of capital regulation when simple equity will provide a more reliable cushion. Preserving the tax benefits of debt is not a legitimate reason, and the potential role of contingent capital in resolving frictions associated with governance has not been established.

A clear recommendation that emerges from our analysis is that prohibiting, for a period of time, dividend and other equity payouts for all banks is a prudent and efficient way to help banks build capital. If done under the force of regulation, these payout suspensions would not lead to any negative inference on the health of any particular bank. In addition, as mentioned above, 
regulators can remove the stigma associated with equity issuance, as well as frictions related to debt overhang, by requiring banks to issue equity on a pre-specified schedule.

In the post-crisis debate about banking regulation, the case is often made that higher capital requirements would move important activities from the regulated parts of the financial system to the unregulated parts, the so-called shadow banking system, where leverage often is even higher than in the regulated banking system. It is true that over the two decades, the shadow-banking system has seen enormous growth and that high leverage of institutions and the resulting fragility of institutions in this system has been a major factor in turning the crisis of subprime-mortgagebacked securities into a global financial crisis. However, most of the very highly leveraged and very fragile institutions in the shadow banking system were not independent units but conduits and structured-investment vehicles that had been created and guaranteed by financial institutions in the regulated sector. The sponsoring banks used these devices to evade the regulation to which they were subjected. This "regulatory arbitrage" succeeded only because bank supervisors allowed it. ${ }^{6}$ Instead supervisors should have insisted on proper accounting and risk management for the risks inherent in the guarantees that regulated banks had given to their shadow banking subsidiaries. Thus, the movement of activities from regulated banks to the shadow banking system is not inescapable, and regulators have the tools with which to address it. ${ }^{7}$

Our discussion focuses on the social costs and benefits of using common equity as a way to fund banks. We do not consider other types of claims to be useful in providing a reliable cushion. Indeed, the recent crisis has shown that Tier 2 capital, i.e., subordinated debt, does not provide a reliable cushion. Proposals have been made to substitute "contingent capital," i.e., a debt-like security that converts to equity under some conditions, for subordinated debt to or using "bail-in" mechanisms to try to improve the cushion provided by Tier 2 capital. Our view is that, since there is no compelling case that the debt-like features of these securities provide social value, capital regulation should focus entirely on equity.

We do not address all the issues that regulators confront in regulating financial institutions. In particular, we do not discuss in detail which banks or financial institutions should be regulated, the distinction between large and small banks, or the issue of micro vs. macro prudential regulation. Our discussion applies most urgently to those institutions whose leverage imposes negative externalities on the financial system as a whole, i.e., "systemic risk" and which are "too important" or "too interconnected" to fail. However, a workable definition of such "systemic" institutions raises a host of additional questions, which go beyond the scope of this paper. Another issue we do not elaborate on here is the risk weights currently used to determine

\footnotetext{
${ }^{6}$ Acharya and Richardson (2009), Acharya, Schnabl, Suarez (2010), Hellwig (2009b), Turner (2010).

${ }^{7}$ It is interesting to note that, in the recent crisis, those parts of the shadow banking systems which were not related to regulated banks sponsoring them, e.g. independent hedge funds, did not experience problems that turned into systemic risks. Ang, Gorovyy, and Inwegen (2011) study hedge fund leverage and show that it has generally been modest, and even through the recent financial crisis.
} 
the size of asset base against which equity is measured. As discussed in Brealey (2006) and Hellwig (2010), this system is easily manipulable and can lead to distortions in the lending and investment decisions of banks. Proposing a way to track the riskiness of banks' assets on an ongoing basis is a challenge beyond the scope of the current paper.

There have been hundreds of papers on capital regulation in the last decade, and particularly since the financial crisis. We cite here some papers that make recommendations similar or related to those we make here. Closest to us are Harrison (2004) and Brealey (2006) who also conclude that there are no compelling arguments supporting the claim that bank equity has a social cost. ${ }^{8}$ Poole (2009) identifies the tax subsidy of debt as distorting, a concern we share. However, he goes on to suggest that long term debt (possibly of the "contingent capital" variety) can provide both a meaningful "cushion" and the so-called "market discipline." As we explain especially in Sections 5.1 and 8, we take issue with this part of his assessment. Turner (2010) and Goodhart (2010) also argue that a significant increase in equity requirements is the most important step regulators should take at this point. Acharya, Gujral, and Shin (2009), Acharya, Mehran and Thakor (2010) and Goodhart et al. (2010) suggest, as we do, that regulators use restrictions on dividends and equity payouts as part of prudential capital regulation. We take this recommendation a step further by suggesting the possibility of mandatory equity issuances as well, not just to control the actions of distressed institutions, but rather as a way to proactively help overcome informational frictions and avoid negative inferences associated with new issues. Such mandates are particularly important in managing a transition to a regime with significantly higher equity requirements. Finally, Kotlikoff (2010) proposes what he calls Limited Purpose Banking, in which financial intermediation is carried out through mutual fund structures. His proposal, like ours, is intended to reduce systemic risk and distortions, especially those associate with excessive risk taking. Our recommendations differs from his in that we allow for financial intermediation to be performed by the same type of structures that currently exist, i.e., intermediaries that can make loans, take deposits and issue other "money-like" claims.

\section{The Benefits of Increased Equity Capital Requirements}

Before examining the arguments that purport to show that increased capital requirements are costly, it is important to review some of the significant benefits associated with better capitalized banks. The recent financial crisis, as well as ones that have preceded it, have made it very clear that systemic risk in the financial sector is a great concern. Financial distress in one large institution can rapidly spill over into others and cause a credit crunch or an asset price implosion. The effects of systemic risk events such as the one just experienced are not confined to the financial sector of the economy. As history has repeatedly demonstrated, these events can have

\footnotetext{
${ }^{8}$ Many authors, including King (1990), Schaefer (1990), Berger, Herring and Szegö (1995), Miller (1995), Brealey (2006), Hellwig (2009b), and French et al. (2010), have emphasized that the Modigliani-Miller Theorem must be the starting point of any discussion of capital regulation.
} 
extremely adverse consequences for the rest of the economy and can cause or deepen recessions or depressions. Lowering the risk of financial distress among those institutions that can originate and transmit systemic risk produces a clear social benefit. ${ }^{9}$

An obvious way to lower systemic risk is to require banks to fund themselves with significantly more equity than they did before the last crisis unfolded. ${ }^{10}$ In the build up to the last crisis important parts of the financial sector had become very highly leveraged. Indeed, several banks had balance sheets in which equity was only two or three percent of assets. ${ }^{11}$ Such a thin cushion obviously leaves little room for error. Even a moderate shock that reduces asset values by one or two percent puts such thinly capitalized banks on the brink of insolvency. Even if it is not actually insolvent, suspicions of its exposure may stop other institutions from providing the short-term funding that it relies on. In the last crisis, even before the breakdown of Lehman Brothers, there were several instances during which interbank markets froze because of such distrust among market participants. With greater capital cushions, there would be less risk of such systemic breakdowns from mutual distrust.

Another consideration concerns corrective measures when losses have occurred. If supervisors - or short-term creditors - are concerned with the bank's capital ratio, then, following a reduction of capital through losses, the bank must either recapitalize or deleverage by selling assets. Deleveraging puts pressure on asset markets, inducing prices to fall, with negative repercussions for other market participants, who also have these assets on their books. The extent of deleveraging depends on what the bank's capital position is. If bank capital is 3\% of the balance sheet, then following a loss of 1 million dollars, the bank attempting to deleverage must liquidate more than 33 million dollars worth of assets just to re-establish that $3 \%$ ratio. The

\footnotetext{
${ }^{9}$ Indeed, BIS (2010a) estimates that a $2 \%$ increase in capital ratios will reduce the probability of a financial crisis by 2.9\%. The Bank of Canada (2010) estimates the gains that this would produce for the Canadian economy alone as equivalent to an annual benefit on the order of $2 \%$ of GDP.

${ }^{10}$ It is interesting to note that banks in the U.S. and in the U.K. were not always as highly leveraged as they have been in recent decades. According to Berger, Herring and Szegö (1995), in 1840 equity accounted for over 50\% of bank total value, and the increase in leverage can be traced to additional measures to create a "safety net" for banks. Moreover, until the establishment of the FDIC in 1944, the liability of the equity issued by banks was not limited as it is today. Instead, bank equity had double, triple and sometimes unlimited liability, which meant that equity holders had to cover losses and pay back debt even after losing the entire amount they invested. Haldane (2009) shows a similar pattern in the U.K. For Germany, a similar decline is documented by Holtfrerich (1981); not surprisingly, however, the evolution here mirrors historical discontinuities associated with the two World Wars and the inflation of 1914-1923, as well as the long-term trend which set in long before 1914.

${ }^{11}$ Of course, banks appeared to be better capitalized in percentage terms when their capital was measured relative to "risk weighted assets." The risk weightings used in these measures are highly problematic. Banks have exploited the freedom given them by the risk-calibrated approach to determining capital requirements in order to dramatically expand the activities supported by the equity they had. Many of the risks that materialized in the crisis, however, had not even been considered in risk weights beforehand. Moreover, true leverage was often masked through accounting maneuvers, especially in connection with the so-called shadow banking system. On the shadow banking system, see Pozsar et al (2010). On the use of the risk-calibrated approach to expand activities supported by a given level of equity, see Hellwig (2009, 2010). Hellwig (2010) suggests that notions of measurement of risks that underlie the risk-calibrated approach are largely illusionary.
} 
systemic repercussions on asset prices and on other institutions will be accordingly large. Capital requirements based on higher equity ratios would reduce the chances that such chain reactions occur, and would dampen those that do occur.

If governments see the need to avoid the social costs of systemic crises by stepping in to support their banking sectors, then an additional benefit of increased equity requirements comes from reducing the burden on taxpayers. This benefit is produced in two ways. First, increased equity requirements reduce the probability that bailouts will be necessary, since the equity cushion of the bank can absorb more substantial decreases in the asset value without triggering a default. Second, if a bailout does become necessary, the amount of required support would generally be lower with a larger equity cushion, since a larger portion of losses would be absorbed by the equity. Both the diminished probability of a systemic event and the decreased amount of support required in the event of a crisis significantly reduce the costs to taxpayers.

There are additional benefits of higher equity capital requirements beyond the major ones just given. These are generally related to the reduction in conflicts of interest and the more aligned incentives that are created with less leverage. In particular, more equity capital reduces the incentives of equity holders (and managers working on their behalf or compensated by return on equity (ROE)) to undertake excessively risky investments. This will be discussed in more detail in Sections 4.2 and 5.1 below.

In the remainder of the paper we argue that the social costs of significantly higher equity requirements are minimal, if any. Given the very large benefits associated with higher equity levels, the case for requiring much more equity is extremely strong. Many representatives of the banking community make strong assertions about the costs of bank equity requirements, while deemphasizing or paying lip service to the substantial benefits associated with the reduction of systemic risk that result from more equity funding of banks. Given the cost of the crisis to the global economy, such a debating stance is quite incredible. Policy recommendations regarding capital regulation must be based on an analysis that accounts as fully as possible for the social cost and benefits associated with any change in equity requirements. ${ }^{12}$

\section{Capital Structure Fallacies}

Capital requirements place constraints on the capital structure of the bank, i.e., on the way the bank funds its operations. Any change in a bank's capital structure changes the exposure of different securities to the riskiness of the bank's assets. In this section we take up statements and

\footnotetext{
${ }^{12}$ While BIS (2010) and Miles et. al. (2011) attempt to quantify the benefits as well as the costs of increased equity requirements, a recent NY Fed Staff Report (Angelini et al., 2011), entitled "BASEL III: Long-Term Impact on Economic Performance and Fluctuations," focuses almost entirely on purported costs, while essentially ignoring the key benefits of increased equity requirements.
} 
arguments that are based on confusing language and faulty logic regarding this process and its implications. The debate on capital regulation should obviously not be based on misleading and fallacious statements, so it is important to make sure they are removed from the discussion.

\title{
3.1 What is Capital and What are Capital Requirements?
}

\begin{abstract}
"Capital is the stable money banks sit on... Think of it as an expanded rainy day fund.” (“A piece-by-piece guide to new financial overhaul law,” AP July 21, 2010).
\end{abstract}

"Every dollar of capital is one less dollar working in the economy" (Steve Bartlett, Financial Services Roundtable, reported by Floyd Norris, “A Baby Step Toward Rules on Bank Risk,” New York Times, Sep. 17, 2010).

“The British Bankers' Association ... calculated that demands by international banking regulators in Basle that they bolster their capital will require the UK's banking industry to hold an extra £600bn of capital that might otherwise have been deployed as loans to businesses or households.” The Observer (July 11, 2010)

Statement: "Capital represents money that banks must set aside and keep idle, and it cannot be uses productively.”

Assessment: This statement and the above quotes are false and misleading. They confuse the two sides of the balance sheet. They portray capital as idle and thus costly. In fact, capital requirements address how banks are funded, not what assets they invest in or hold, and they do not require setting aside funds and not investing productively; once reserve or liquidity requirements are met, all bank capital can be deployed to make loans or otherwise invest and earn market returns or higher.

Equity simply represents an ownership claim in the form of common shares of stocks, such as those traded on stock markets. Equity is considered a "cushion" or a "buffer" because its holders do not have a hard claim against the issuer; if earnings turn out to be low or even negative, the bank can lower its payout to equity holders without any notion of default.

Bank capital regulation also allows securities other than common stock to be counted as "regulatory capital." Most of these are hybrid securities that have some features of debt and some of equity. The typical hybrid security tends to involve a fixed claim, like debt, but this claim is subordinated to all other debt. Moreover, debt service on the hybrid security may be suspended 
when the bank makes a loss; under certain conditions even the capital value may be written down. In the recent financial crisis, however, there were many instances of banks being supported by public money without any burden sharing by debt holders including holders of hybrid securities that counted as regulatory capital. Under Basel III (see BIS (2010b), the rules regarding what is included in regulatory capital will be tightened.

In the rest of the paper we focus exclusively on equity. Given the difficulty in renegotiating or inflicting losses on debt-like claims in a crisis, our assessment is that capital requirements should focus entirely on equity, because it is the most reliable buffer for preventing a crisis and because, as we argue below, equity is not expensive from a social perspective.

\subsection{Equity Requirements and Balance Sheet Mechanics}

"More equity might increase the stability of banks. At the same time however, it would restrict their ability to provide loans to the rest of the economy. This reduces growth and has negative effects for all.” Josef Ackermann, CEO of Deutsche Bank (November 20, 2009, interview). ${ }^{13}$

"[C]apital adequacy regulation can impose an important cost because it reduces the ability of banks to create liquidity by accepting deposits." Van den Heuvel (2008, p. 299).

Statement: "Increased capital requirements force banks to operate at a suboptimal scale and to restrict valuable lending and/or deposit taking."

Assessment: To the extent that this implies balance sheets must be reduced in response to increased equity requirements, or that deposits must be reduced, this is false. By issuing new equity if necessary, banks can respond to increased capital requirements without affecting any of their profitable or socially valuable activities.

Statements such as the ones above predict that potentially dire consequences would result from increasing capital requirements, and these have received the attention of regulators and policy makers. While one should be concerned about the effect proposed regulations might have on the ability of banks to carry out their core business activities, increasing the size of the equity cushion does not in any way mechanically limit the ability of a bank to lend.

\footnotetext{
${ }^{13}$ This and other quotations cited in the paper are intended to be representative of common arguments that have entered the policy debate on capital regulation. They may not reflect the complete or current views of those cited.
} 
To see this, consider a very simple example. Assume that capital requirements are initially set at $10 \%$ : a bank's equity must be at least $10 \%$ of the value of the bank's assets. ${ }^{14}$ For concreteness, suppose that the bank has $\$ 100$ in loans, financed by $\$ 90$ of deposits and other liabilities, and $\$ 10$ of equity, as shown in the initial balance sheet in Figure 1.

Now assume that capital requirements are raised to 20\%. In Figure 1 we consider three ways in which the bank balance sheet can be changed to satisfy the higher capital requirement, fixing the value of the bank's current assets. ${ }^{15}$ One possibility is shown in Balance Sheet A, where the bank "delevers" by significantly scaling back the size of its balance sheet, liquidating \$50 in assets and using the proceeds to reduce total liabilities from \$90 to \$40. In Balance Sheet B, the bank satisfies the higher 20\% capital requirement by recapitalizing, issuing $\$ 10$ of additional equity and retiring $\$ 10$ of liabilities, and leaving its assets unchanged. Finally, in Balance Sheet $\mathrm{C}$, the bank expands its balance sheet by raising an additional \$12.5 in equity capital and using the proceeds to acquire new assets.

Figure 1: Alternative Responses to Increased Equity Requirements

Initial Balance Sheet

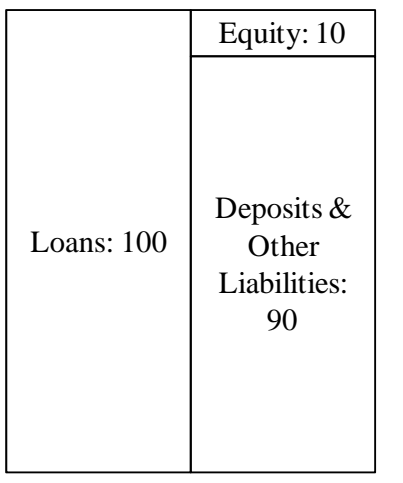

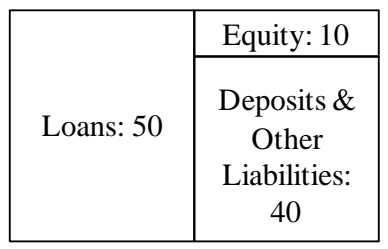

A: Asset Liquidation

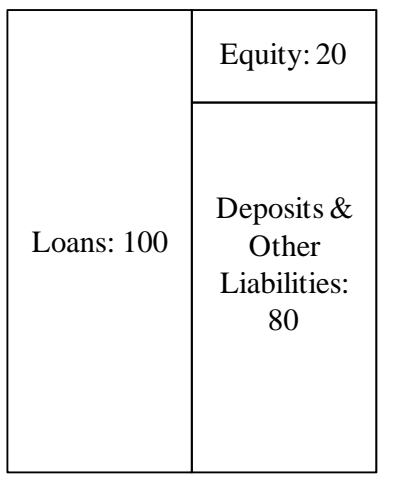

B: Recapitalization

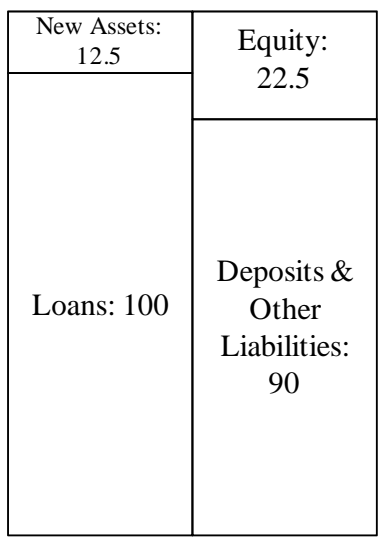

C:Asset Expansion

Note that only when the bank actually shrinks its balance sheet, as shown in A, is the bank reducing the amount of lending it can undertake. In both $\mathrm{B}$ and $\mathrm{C}$ the bank can support the same amount of lending as was supported by the original balance sheet.

\footnotetext{
${ }^{14}$ To keep the examples straightforward, we consider simplified versions of capital requirements. Actual current capital requirements are based on risk adjustments and involve various measures of the bank’s capital (e.g., Tier 1 and Tier 2). The general points we make throughout this article apply to more complex requirements.

${ }^{15}$ In this example, we are focusing on the mechanics of how balance sheets can be changed to meet capital requirements. We are intentionally ignoring for now tax shields and implicit government guarantees associated with a bank's debt financing, as well as how changes in a bank's capital structure alter the risk and required return of the bank's debt and equity. We discuss these important issues in detail in subsequent sections.
} 
In balance sheet B some liabilities are replaced with equity. Specific types of liabilities, such as deposits, are part of a bank's "production function" in the sense that their issuance is related to the provision of transactions and other convenience services that the bank provides to its customers. At a first glance, therefore, balance sheet B might seem to imply that higher capital requirements force the bank to reduce its supply of deposits, which would be socially costly if the associated services are both profitable for the bank and beneficial for the economy. ${ }^{16}$ In practice, however, deposits are not the sole form of bank liabilities. For example, non-trivial portions of bank finance, especially for large commercial banks, come in the form of long term debt. Replacing a portion of this long term debt with equity will increase bank capital without reducing its productive lending and deposit-taking activity. ${ }^{17}$ Given the fact that banks are not wholly funded by deposits, banks can meet increased capital requirements without reducing the amount of their deposits or the amount of their assets.

It is also possible that complying with higher capital requirements does not reduce the dollar value of either the liabilities or the assets. Balance Sheet $\mathrm{C}$ meets the higher capital requirements while keeping both the original assets (e.g. loans) and all of the original liabilities of the bank in place. Additional equity is raised and new assets are acquired. In the short run, these new assets may simply be cash or other marketable securities (e.g. Treasuries) held by the bank. As new, attractive lending opportunities arise, these securities provide a pool of liquidity for the bank to draw upon to expand its lending activity. One might worry that it would be costly or inefficient for the bank to hold additional securities or one might be concerned about the impact of such a change on the overall demand and supply of funding. We discuss these issues in detail in Section 7 and comment on implementation issues in the concluding remarks (Section 9).

To summarize, in terms of simple balance sheet mechanics, the notion that increased equity capital requirements force banks to reduce deposits and/or lending activities is simply false. Banks can preserve or even expand lending activities by changing to Balance Sheets B or C. So, if higher capital requirements are to reduce lending activities, it must be that these changes involve some additional costs, or that certain frictions lead the bank to pass up profitable loans.

We have phrased this discussion in terms of a single bank and its balance sheet. Our argument is just as pertinent, however, when analyzing the banking sector as a whole or even the overall economy. A notable example can be found in van den Heuvel (2008), which derives a

\footnotetext{
${ }^{16}$ For example, Gorton (2010), Gorton and Metrick (2009), Stein (2010) and others argue that short-term liabilities and deposits command a "money-like" convenience premium based on their relative safety and the transactions services that safe claims provide. Gorton and Pennacchi (1990) and Dang, Gorton and Holmström (2010) stress the importance of the "information insensitivity" of these claims in providing these services. Van den Heuvel (2008) considers the loss of convenience services from deposits to be the major welfare cost of bank capital regulation.

17 According to the FDIC website, as of March 31 ${ }^{\text {st }}$, 2010, domestic deposits at U.S. commercial banks totaled $\$ 6,788$ billion, which represented $56.2 \%$ of total assets, while equity represented $10.9 \%$ of assets. This leaves $32.9 \%$ of the assets, which is almost $\$ 4$ trillion in non-deposit liabilities. Quite possibly, some of these liabilities can be converted to equity without affecting the provision of important bank services.
} 
formula that has been used by policy analysts to evaluate the impact of increased capital requirements. His model assumes that banks are financed only with equity and deposits and makes assumptions that guarantee that no risky firms exist in equilibrium and that the only equity claims held in equilibrium are those issued by the bank. Effectively these restrictive assumptions preclude an adjustment to higher capital requirements of the sort depicted in Balance Sheet C. Increased capital requirements thus require that bank's substitute equity for deposits, resulting in a welfare loss under the model's assumption that consumers derive utility from holding deposits. Given that in reality banks can satisfy higher capital requirements without reducing their deposit base, applying this model to assess the welfare costs of capital requirements seems highly suspect if not meaningless. ${ }^{18}$

In the sections that follow, we examine various claims that have been made suggesting that increased equity capital requirements entail high costs or create distortions in lending decisions.

\title{
3.3 Equity Requirements and Return on Equity (ROE)
}

\begin{abstract}
"Banks... do not want to hold too much capital because by so doing they will lower the returns to equity holders.” Mishkin and Aekin (2009, p. 444)

"Demands for Tier-1 capital ratio of $20 \%$... could depress ROE to levels that make investment into the banking sector unattractive relative to other business sectors.” Ackermann (2010, p. 5.)
\end{abstract}

Statement: "Increased equity requirements will hurt bank shareholders since it would lower the banks return on equity (ROE).”

Assessment: This is false; a reduction in ROE does not indicate decreased value added. While increased capital requirements can lower the Return on Equity (ROE) in good times, they will raise ROE in bad times, reducing shareholder risk.

One concern about increasing equity capital requirements is that such an increase will lower the returns to the bank's investors. In particular, the argument is often made that higher equity capital requirements will reduce the banks' Return on Equity (ROE) to the detriment of their shareholders. ${ }^{19}$

\footnotetext{
${ }^{18}$ Given these limitations, we find it remarkable that some in the regulatory community are using the van den Heuvel (2008) formula in assessing the welfare costs of capital regulation under Basel III; see for example NY Fed Staff Report by Angelini et al (2011). Van den Heuvel (2008) himself comes to the conclusion "that capital requirements are currently too high” (p. 316). One upper bound for the cost that he gives stands at $\$ 1.8$ billion per year for an increase in equity capital requirements by one percentage point (p.311). Given the role of insufficient equity in the crisis that followed, his assessment seems as problematic as his method.

${ }^{19}$ Accounting ROE is defined as net income / book value of equity. A related financial measure is the earnings yield, which is net income / market value of equity, or equivalently, the inverse of the bank's P/E multiple. The
} 
This argument presumes that ROE is a good measure of a bank's performance. Since ROE (or any simple measure of the bank's return) does not adjust for scale or risk, there are many potential pitfalls associated with this presumption. Using ROE to assess performance is especially problematic when comparisons are made across different capital structures. The focus on ROE has therefore led to much confusion about the effects of capital requirements on shareholder value.

We illustrate the consequence of an increase in equity capital on ROE in Figure 2. This figure shows how the bank's realized ROE depends on its return on assets (before interest expenses). For a given capital structure, this dependence is represented by a straight line. ${ }^{20}$ This straight line is steeper the lower the share of equity in the bank's balance sheet. Thus, in Figure 2 , the steeper line corresponds to an equity share of $10 \%$, the flatter line to an equity share of $20 \%$. The two lines cross when the bank's ROE is equal to the (after-tax) rate of interest on debt, assumed to be $5 \%$ in the figure. ${ }^{21}$ Above that level, ROE is indeed lower with higher capital. Below the 5\% level, however, ROE is higher with higher capital, as the cushioning effect of higher capital provides downside protection for equity holders and reduces their risk.

\section{Figure 2: The Effect of Increased Equity on ROE}

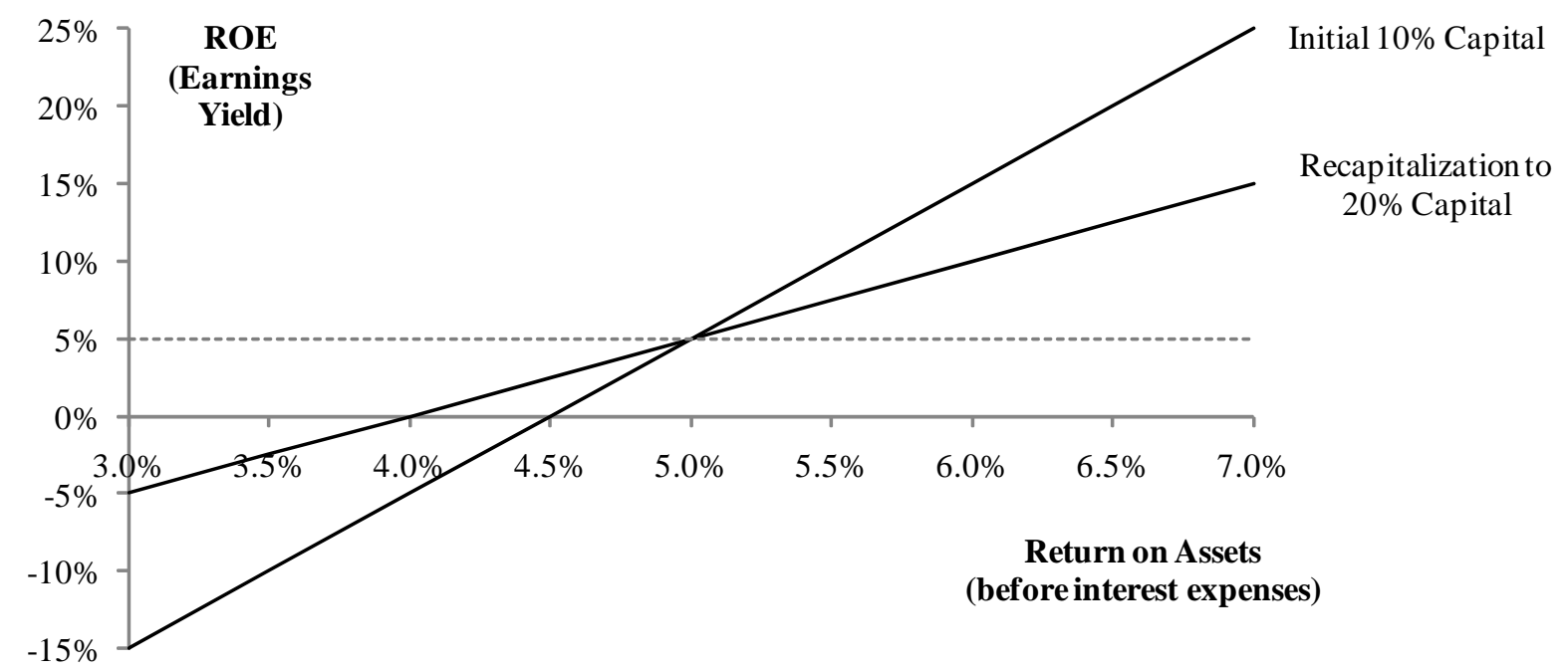

The figure illustrates the following key points:

discussion in this section applies equally well to the earnings yield, replacing book values with market values throughout.

${ }^{20}$ More precisely, $\mathrm{ROE}=(\mathrm{ROA} \times \mathrm{A}-\mathrm{r} \times \mathrm{D}) / \mathrm{E}=\mathrm{ROA}+(\mathrm{D} / \mathrm{E})(\mathrm{ROA}-\mathrm{r})$, where ROA is the return on assets, $\mathrm{A}$ is the total value of the firm's assets, $\mathrm{E}$ is equity, $\mathrm{D}$ is debt, and $\mathrm{r}$ is the (after-tax) interest rate on the debt.

${ }^{21}$ If the bank had met the higher capital requirements by expanding its assets rather than recapitalizing (Case $\mathrm{C}$ in Figure 1), the "break-even” ROE would be the after-tax return of the new assets acquired by the bank. 
- For a given capital structure, ROE does reflect the realized profitability of the bank's assets. But when comparing banks with different capital structures, ROE cannot be used to compare their underlying profitability. ${ }^{22}$

- Higher equity capital requirements will tend to lower the bank's ROE only in good times when ROE is high. They will raise the ROE in bad times when ROE is low. From an ex ante perspective, the high ROE in good times that is induced by high leverage comes at the cost of having a very low ROE in bad times.

On average, of course, banks hope to (and typically do) earn ROE well in excess of the return on their debt. In that case, the "average" effect on ROE from higher equity capital requirements would be negative. For example, if the bank expects to earn a 6\% return on its assets, then it would expect a 15\% ROE on average with 10\% capital, and only a 10\% ROE on average with $20 \%$ capital. Is this effect a concern for shareholders?

The answer is no. Because the increase in capital provides downside protection that reduces shareholders' risk, shareholders will require a lower expected return to be willing to invest in a better capitalized bank. This reduction in the required return for equity will offset the reduction in the average ROE, leading to no net change in the value to shareholders (and thus the firm's share price). Indeed, in the above example, if the equity investors required a $15 \%$ expected return initially, we would expect their required return to fall to $10 \%$ due to the reduction in risk with the increase in the firm's capital. ${ }^{23}$ Because shareholders continue to earn their required return, there is no cost associated with the increase in equity capital. ${ }^{24}$

\subsection{Capital Structure and the Cost of Capital}

"The problem with [equity] capital is that it is expensive. If capital were cheap, banks would be extremely safe because they would hold high levels of capital,

\footnotetext{
${ }^{22}$ For example, a manager who generates a 7\% ROA with 20\% capital will have an ROE of 15\%. Alternatively, a less productive manager who generates a $6.5 \%$ ROA yet has $10 \%$ capital will have an ROE of $20 \%$. Thus, when capital structures differ, a higher ROE does not necessarily mean a firm has deployed its assets more productively.

${ }^{23}$ To see why, note from Figure 2 that doubling the bank's capital cuts the risk of the bank's equity returns in half (the same change in ROA leads to $1 / 2$ the change in ROE). Thus, if shareholders initially required a $15 \%$ average return, which corresponds to a $10 \%$ risk premium to hold equity versus safe debt, then with twice the capital, because their sensitivity to the assets' risk (and thus their "beta”) has been halved, they should demand $1 / 2$ the risk premium, or $5 \%$, and hence a $10 \%$ required average return.

${ }^{24}$ As we have seen, because of ROE's failure to account for both risk and capital structure, it is not a useful measure of a manager's contribution to shareholder value. Most management experts prefer alternatives such as the firm's economic value added (EVA) or residual income. Residual income is defined as (ROE $\left.-r_{E}\right) \times \mathrm{E}$, where $r_{E}$ is the firm's risk-adjusted equity cost of capital, and $\mathrm{E}$ is the firm's equity. Residual income thus adjusts both for the risk and scale of the shareholders' investment. Simple changes in capital structure will not alter the firm's residual income.
} 
providing full protection against even extreme events. Unfortunately, the suppliers of capital ask for high returns because their role, by definition, is to bear the bulk of the risk from a bank's loan book, investments and operations” Elliott (2009, p. 12).

Statement: "Increased equity requirements increase the funding costs for banks because they must use more equity, which has a higher required return.”

Assessment: This argument is false. Although equity has a higher required return, this does not imply that increased equity capital requirements would raise the banks' overall funding costs.

The example of the previous section exposes a more general fallacy regarding equity capital requirements. Because the required expected rate of return on equity is higher than that on debt, some argue that if the bank were required to use more of this "expensive" form of funding, its overall cost of capital would increase.

This reasoning reflects a misunderstanding of the way in which risks affect the cost of funding. While it is true that the required return on equity is higher than the required return on debt and it is also true that this difference reflects the greater riskiness of equity relative to debt, it is not true that by "economizing" on equity one can reduce capital costs. "Economizing" on equity itself has an effect on the riskiness and, therefore, on the required expected return of equity. This effect must be taken into account when assessing the implications of increased equity capital requirements for banks' cost of capital.

Figure 2 indicates that the random fluctuations in the bank's ROE that are induced by a given fluctuation in earnings are greater the less equity the bank issues. When the bank is funded with relatively more equity, a given earnings risk translates into less risk for its shareholders. Reflecting this reduction in risk, the risk premium in the expected ROE will be lower. If the additional equity capital serves to reduce the bank's bankruptcy risk, the interest rate on its debt will also be lower. These reductions of risk premia in required rates of return counteract the direct effects of shifting from debt finance to equity finance, from an instrument with a low required rate of return to an instrument with a higher required rate of return. The net effect need not increase the total funding costs of the bank at all. ${ }^{25}$

One of the fundamental results of corporate finance (Modigliani and Miller, 1958) states that, absent additional considerations such as those involving tax advantages or public subsidies to debt, increases in amount of financing done through equity simply re-distributes the total risk

\footnotetext{
${ }^{25}$ Continuing our earlier example (see $\mathrm{fn} .11$ ), given $10 \%$ equity capital the required return was $15 \%$ for equity and $5 \%$ for debt, for an average cost of $10 \% \times 15 \%+90 \% \times 5 \%=6 \%$. With $20 \%$ equity capital the required return for equity falls to $10 \%$ (with a $5 \%$ cost of debt), leading to the same average cost of $20 \% \times 10 \%+80 \% \times 5 \%=6 \%$.
} 
that must be borne by investors in the bank, i.e., the holders of debt and equity and any other securities that the bank may issue. The total risk itself is given by the risks that are inherent in the bank's asset returns. In a market in which risk is priced correctly, an increase in the amount of equity financing lowers the required return on equity in a way that, absent subsidies to bank debt and other frictions, would leave the total funding costs of the bank the same.

The Modigliani-Miller analysis is often dismissed on the grounds that the underlying assumptions are highly restrictive and, moreover, that it does not apply to banks, which get much of their funding in the form of deposits. The essence of this result, however, is that in the absence of frictions and distortions, changes in the way in which any firm funds itself does not change either the investment opportunities or the overall funding costs determined in the market by final investors. The one essential assumption is that investors are able to price securities in accordance with their contribution to portfolio risk, understanding that equity is less risky when a firm has less leverage i.e., funds itself with less debt. ${ }^{26}$ The validity of this assumption, even for banks, is supported by substantial empirical evidence. ${ }^{27}$ Indeed, it is the analogue to the observation in debt markets that the yield on junior debt will increase with an increase in the amount of senior debt; or equivalently, yields vary inversely with seniority.

As for the argument that the Modigliani-Miller analysis does not apply to banks, there is some truth to the notion that deposits and perhaps some other liabilities issued by banks are different due in part to the transactions services they provide. As we discuss in Sections 5.1 and 7, the ability to provide liquidity and other transaction services does not require that banks be very highly leveraged and fragile and can be enhanced if they are not so highly leveraged.

The assumptions underlying the Modigliani-Miller analysis are in fact the very same assumptions underlying the quantitative models that banks use to manage their risks, in particular, the risks in their trading books. Anyone who questions the empirical validity and relevance of an analysis that is based on these assumptions is implicitly questioning the reliability of these quantitative models and their adequacy for the uses to which they are put including that of determining required capital under the model-based approach for market risks. If we cannot count on markets to correctly price risk and adjust for even the most basic consequences of changes in leverage, then the discussion of capital regulation should be far more encompassing than the current debate.

\footnotetext{
${ }^{26}$ In particular, the result does not presume full investor "rationality" in the sense that investors must maximize a utility function, etc. For the most general formulation of the Modigliani and Miller (1958) result, see Stiglitz (1969, 1974), Hellwig (1981), and DeMarzo (1988). For comments on the relevance of Modigliani and Miller's insight to banking, see Miller (1995) and Pfleiderer (2010).

${ }^{27}$ See, for example, Hanson, Kashyap, and Stein (2010).
} 


\section{Arguments Based on a Confusion of Private and Social Costs}

In practice, changing the capital structure of a bank (or any firm) does more than shift how risk is distributed among those who fund its operations. For example, alterations in a bank's capital structure can change how much the bank pays in taxes and can influence how investment and other decisions are made by bank managers. In this and the following sections we address the potential costs and benefits of equity capital requirements when various distortions and frictions are taken into account.

In this section we address distortions and frictions that involve the interaction between banks and the government. There are two important ways in which government policy affects the investment and financing decisions of banks. The first involves taxes, mentioned above, and is common to banks and other corporations. In most countries where corporations must pay corporate taxes, interest payments on debt are considered a tax deductible expense. This gives debt financing an advantage over equity financing, because the more debt a profitable firm has, the lower its tax bill, other things being equal.

The second important feature of the interactions of banks and governments involves debt guarantees that the government may provide - in particular to banks that are deemed too important to fail. When investors believe that the government might step in to bail out banks in times of distress, banks can borrow at a lower rate than they would absent the possibility of a bailout. Unless the bank is forced to pay the government a fair insurance premium upfront, government guarantees work like a subsidy that results in lower funding costs when debt, not equity, is used to finance a bank's operation. ${ }^{28}$

As a result of both tax and implicit guarantees (for which they are not charged upfront), banks find debt a very attractive form of financing. It is therefore not surprising that bankers argue that equity capital requirements will increase their funding costs, since indeed more equity will reduce their ability to benefit from these subsidies. However, we argue below that this is not a legitimate reason for regulators to refrain from increasing capital requirements. In fact, it is quite paradoxical that the government subsidizes the leverage of the banks at the same time that it recognizes that this leverage is socially very costly and considers imposing stricter capital requirements to prevent the banks from taking advantage of this subsidy. If there are specific frictions that banks encounter in their activities and which prevent them from lending at a socially optimal level, the government might wish to resolve such frictions using subsidies. However, policies that encourage leverage should be avoided.

\footnotetext{
${ }^{28}$ Explicit guarantees such as through FDIC insurance, are different in that banks are supposedly charged for them upfront. Such insurance is only provided to deposits that are considered socially valuable and where the threat of inefficient runs is great. See further discussion of this at the end of Section 4.2
} 


\subsection{Taxes}

"In the real world of tax biases in favor of debt... there clearly is a private cost penalty to higher equity requirements, and the case that tighter [capital] requirements increase the cost of long-term credit provision appears fairly clear." Turner (2010, p. 25)

Statement: "Increased equity requirements increase the funding costs for banks because they reduce the ability of banks to benefit from the tax shield associated with interest payments on debt.”

Assessment: When debt has a tax advantage over equity, this statement is true. However, it is irrelevant to capital regulation in the sense that both capital regulation and taxes are matters of public policy. The current tax code creates distortions by subsidizing leverage. These distortions can be eliminated, while preserving the same level of bank tax shields, at the discretion of the government. This would neutralize the tax impact of increased equity requirements.

Since, as discussed above, tax shields effectively subsidize debt financing, requiring banks to use less debt financing can raise banks' cost of capital. ${ }^{29}$ From a public-policy perspective, however, this effect is irrelevant as it concerns only the distribution of public money. The tax savings that a bank obtains by relying on debt rather than equity finance reduce the government's tax revenue and require either a reduction in spending on public goods or an increase in taxes elsewhere. While the bank gains from the debt tax shield, the public loses, and ultimately, the argument concerns the optimal structure of taxation. Taxes should be structured to minimize the overall distortions they induce. In addition, taxes (and subsidies) should be set so as to encourage behavior that generates positive externalities and to discourage behavior that generates negative externalities.

By these criteria, refraining from requiring banks to have more equity capital on the grounds that this would raise their taxes makes no sense. If the prospect of saving on corporate income taxes induces banks to be highly leveraged, this generates a negative externality because the increase in leverage raises the probability of a bank failure, weakening the financial system and raising the possibility of taxpayer bailouts. Given these externalities associated with high leverage of financial institutions, tax policy should not encourage leverage. If anything, tax policy should be designed to make banks internalize the social costs imposed by high leverage.

\footnotetext{
${ }^{29}$ Note, however, this effect is mitigated if dividends or capital gains on shares are taxed at a lower rate than interest income at the level of personal income taxation. Whether debt actually has a tax advantage depends on whether the sum of corporate and investor-level taxes on equity income exceeds or falls short of interest income taxes at the personal level.
} 
Even abstracting from the external effects of default, a tax subsidy to debt finance induces a distortion in the allocation of funds between corporations that can borrow extensively and corporations that use more equity finance. Banks that can be highly leveraged because of implicit government guarantees enjoy an additional advantage over other firms, because high leverage allows them to capture a greater tax subsidy. While some of this advantage may be passed on to the firms to which banks provide loans, there is no reason to believe that this suffices to neutralize the distortion.

Whether the tax code should be changed with respect to corporate taxation more broadly or whether the distortions should be corrected at the level of the banking industry, the current situation is clearly undesirable.

Some considerations of optimal tax theory actually suggest that corporate income should not be taxed (at least in expectation). In that sense the current tax code can be thought of as penalizing equity rather than subsidizing debt. (See Mankiw, Weinzierl, and Yagan (2010), as well as Boskin (2010)). Poole (2009) estimates that reducing the corporate tax rate to $15 \%$ and not allowing financial institutions to deduct interest would result in the same total corporate tax expense as was actually incurred by these institutions.

More generally, even without fundamentally changing the tax code, it is quite straightforward to neutralize the impact of increased equity capital requirements on the tax liabilities of banks. Any tax subsidies lost due to a reduction in leverage can be easily replaced with alternative deductions or tax credits. For example, the subsidy to small-business lending that may be seen as being implicit in the tax advantage of banks could be replaced by a tax subsidy at the level of the small businesses themselves, where the subsidy would be much better targeted and therefore much more effective.

\subsection{Bailouts and Implicit Government Guarantees}

Statement: "Increased equity requirements increase the funding costs for banks because they prevent banks from being able to borrow at the low rates implied by the presence of government guarantees.”

Assessment: This statement is again correct, but it concerns only private, not social costs. Government guarantees that allow banks to enjoy cheap debt financing create numerous distortions and encourage excessive leverage and excessive risk taking. Because of the distorted incentives as well as the difficulty for governments to commit never to bail out banks, it is challenging to neutralize this effect by charging banks for the true cost of the guarantees on an ongoing basis. In this context, equity cushions are particularly valuable, as they reduce the likelihood and cost of the guarantees. 
Explicit or implicit government guarantees immunize the banks' creditors against the consequences of a default by the bank. As a result, the default risk premium in the interest rates demanded by the bank's creditors is lower and may even be zero. Institutions that benefit from such guarantees, e.g., institutions that are deemed to be "too big to fail," are therefore able to borrow at lower interest rates. The savings in capital costs that are thereby achieved are the larger the more leverage the bank has.

From a public policy perspective, this effect of increased equity requirements is not relevant because, similar to the case of the tax advantage of debt, it concerns private, rather than social costs of bank capital. The lower borrowing rates benefiting banks and their shareholders have a counterpart in the default risks borne by the taxpayer. Any consideration of social costs must encompass the costs of these risks to taxpayers. Once this is taken into account, one sees that the effects of government guarantees on borrowing rates provide no reason to refrain from requiring banks to have more capital. By the same argument as before, if lower borrowing rates based on government guarantees induce banks to be highly leveraged, this imposes a negative externality on the rest of the economy because the increase in leverage raises the probability of distress and the resulting systemic risk.

The negative externalities here are likely to be even larger than with those associated with the tax benefits of debt finance. The tax benefits of debt finance are largest when the bank does well and makes profits. The subsidy from government guarantees is worth most when the bank does poorly and is unable to service its debt. From an ex ante perspective, this makes it attractive for the bank to engage in strategies that involve a positive default risk. Of course, some default risk may be unavoidable, but to the extent that there is a choice, the availability of explicit or implicit government guarantees of bank debt creates a bias towards choosing risky strategies to exploit the guarantees, providing shareholders with nice returns if they succeed and saddling the government with the losses if they fail.

As is well known, such a bias towards choosing an excessively risky strategy is present even without government guarantees. The mere existence of debt, with a payment obligation that is independent of the bank's asset returns, creates incentives for the bank's shareholders, or for its managers acting on the shareholders' behalf, to take risks according to the principle "heads, I win, tails, the creditor loses." Under these strategies, increases in default probabilities or default returns, which hurt the creditors, are traded for increases in returns in the event where everything goes well, which benefit shareholders. From the perspective of the debt holders, this is a moral hazard problem, i.e., it is a hazard that is not due to natural perils outside of the participants' sphere of influence, but due instead to the behavior of the banks and the bank's managers who control the use of the funds. 
In the absence of any government guarantees, the bank's creditors would try to limit such moral hazard. If it were possible to write contracts so that the bank's strategy choices are fully committed ex ante, the parties would mutually agree to put such covenants into their contracts. If such commitments are ineffective, the creditors will ask for higher rates or even refuse to provide the bank with funds altogether. In all of those cases in which effective covenants cannot be written, the moral hazard will prevent the partners from choosing a fully efficient arrangement, but, given the constraints imposed by the bank's inability to fully commit its strategy ex ante, the arrangement they come up with may be presumed to be second best.

Explicit or implicit government guarantees can greatly reduce the need for the creditors to worry about their bank's strategy choices and default prospects. If the government can be expected to step in when the bank defaults, the creditor generally has no reason to refrain from lending to the bank or to demand a significant default risk premium. The resulting arrangement may be far from even second best.

Politicians are fond of saying that we must make sure bailouts never happen. In fact, it is extremely difficult, if not impossible, to commit never to bail out a financial institution. Indeed, it may not even be desirable to make such a commitment, since a bailout might be the preferred course of action during a crisis. For this reason the focus must be on structuring financial regulations to minimize or ideally eliminate the possibility that institutions will need to be bailed out. Some recent proposals for financial regulation involve the creation of a "resolution authority" that will have funds ready to help banks and other financial institutions in situations of financial distress. If the government charged a fee (a form of "bank tax") for the protection it is giving through this mechanism, and if this fee always reflected the true cost of the guarantees, then the subsidy associated with implicit guarantees would be removed. However, adapting the fee to the risks that are actually taken would be challenging. More importantly, if it is difficult to monitor risks, then individual banks would have incentives to take on additional risks. This approach is not as effective as requiring significant increases in equity requirements. Equity, as a form of self insurance, will be priced based on its risk directly by financial markets. ${ }^{30}$

Systems providing "safety nets" to banks, including deposit insurance, the Fed's discount window, and "lender of last resort," can and do play a positive role as a stabilizing force, particularly in preventing bank runs that had routinely plagued banks. It is often difficult to price explicit guarantees, and implicit guarantees clearly provide a subsidy to the institution whose

\footnotetext{
${ }^{30}$ Deposit insurance is, of course, a system that collects insurance fees and explicitly insures deposits. Extending this system to additional deposits can be considered and might make sense. However, this should only be appropriate for the type of deposits that create an important social benefit and not to all bank debt. In any event, this should not be viewed as an alternative to significant increases in capital requirements.
} 
debt falls under the guarantees. In this case, the effect is that leverage is again subsidized. ${ }^{31}$ Indeed, as discussed above, the system of capital regulation is motivated by the recognition that guarantees generate distortions and moral hazard problems. Higher equity requirements, by requiring that those who own residual claims in the bank bear much of the bank's risk, reduce dependence on systems of guarantees and, instead, rely more on the private sector to provide safety to the financial system. Thus, they alleviate the distortions associated with the safety net. ${ }^{32}$

\section{Arguments Based on Inadequate Theory}

The distortions and frictions discussed in the previous section are the result of government policies that provide subsidies to banks by lowering their cost of debt financing. These distortions and frictions unambiguously encourage banks to take on high leverage that is socially costly. The clear implication is that these distortions and frictions should be removed or neutralized through changes in public policy. In this section, by contrast, we focus on frictions that are inherent to the environment in which banks operate and are therefore largely unavoidable. These frictions arise because different participants, including bank managers, various creditors, and other investors, are likely to have different information, conflicting preferences, and differing control rights over the banks' investment and financing decisions, and because it is difficult or costly for the various participants to write complete contracts or make credible commitments to actions that will be taken in the future.

Over the last 40 years, a large literature in finance and economics has studied these types of frictions. The parts of this literature that are most relevant to the debate on bank capital regulation are those having to do with financial contracting and the role that different types of securities play in either reducing or increasing these frictions. In this section we consider claims that debt has a positive role to play in alleviating informational and governance frictions, and that for this reason it might be costly to increase equity capital requirements.

In Section 5.1, we consider the claim that debt is informationally insensitive and therefore provides a socially beneficial means of financing banks. ${ }^{33}$ Informational insensitivity is deemed to be useful because it eliminates problems of adverse selection in trading and therefore

\footnotetext{
${ }^{31}$ On the size and distortions associated with bailouts and the safety net, see Akerlof and Romer (1993), CarboValverde et al. (2011), Gahndhi and Lustig (2010), Haldane (2009, 2010), and Kane (2010). For a general discussion on moral hazard problems created by leverage and bailouts, see Geanakoplos (2010).

${ }^{32}$ Unfortunately, in recent years, the "safety net" of the banking sector seems to be expanding rather than contracting. According to Walter and Weinberg (2002), 45\% of bank liabilities in the US were implicitly or, explicitly guaranteed in 1999. Malysheva and Walter (2010) estimate that this grew to 59\% in 2008. Some have proposed recently that the safety net should be further expanded. For example, Gorton (2010, p.17), suggests expanding it to cover the so-called "shadow banking system" which, he argues "serves an important function, which should be recognized and protected.” In his words, “[c]reating a new Quiet Period requires that 'bank' debt be insured.” Gorton's approach would result in further expansion of the safety net, which has the potential to further exacerbate the distortive incentives of guarantees.

${ }^{33}$ See, e.g., Dang, Gorton, Holmström (2009), and Gorton (2010).
} 
contributes to making the markets for these securities liquid. There is some merit to this claim but it does not support the view that leverage should be very high. Indeed, the informational insensitivity of debt that is desired is put at risk if the bank's equity buffer is small.

In Section 5.2 we consider the claim that debt imposes discipline on bank managers and thus alleviates information and governance problems. We consider this claim to be unconvincing. First, this claim neglects the very significant frictions and governance problems that debt and leverage actually create. These include, among other things, problems created by incentives to take excessive risk and the funding problems associated with "debt overhang," problems that quite often lead to inefficient investment decisions. Second, the notion that debt provides discipline to managers simply does not fit the facts of the last decade.

In Section 5.3 we discuss the claim that information asymmetries between investors and managers might make it difficult or costly for banks to issue new equity. While acknowledging the validity of this claim, we argue that such concerns are not adequate to justify high leverage or avoid high equity requirements. In particular, issuance costs are alleviated when leverage is significantly lower on an ongoing basis and growth can be achieved through retained earnings. Moreover, regulators can help remove the stigma associated with equity issuance by imposing recapitalization requirements or restricting equity payouts according to predictable rules applied to all institutions.

Finally, in Section 5.4 we address the notion that observed financing patterns should be regarded as optimal private-sector responses to whatever frictions there are, i.e., that, because we observe banks to be highly leveraged, it follows that this high leverage is privately and perhaps even socially desirable. We point out that, even from a private perspective, contracting can only be optimal relative to the given constraints and, in particular, the given commitment possibilities. Because existing leverage generates incentives to issue additional debt, the high leverage that we observe is at least partly due to the banks' inability to commit themselves to a leverage bound ex ante. In this situation, statutory equity requirements might provide a substitute for the missing ability to commit and in doing so may improve on private contracting even from the participants' perspective.

\subsection{Leverage and the Informational Insensitivity of Debt}

"Debt optimally facilitates trade because debt provides the smallest incentive for private information production, which creates adverse selection.” Dang, Holmström, and Gorton (2010, p. 2).

Statement: "Debt is valuable because it is informationally insensitive. Informational insensitivity has many advantages; in particular, it serves to reduce adverse selection problems that might hurt the liquidity of markets for trading debt instruments." 
Assessment: It certainly is true that, among the securities that a bank might issue, debt is the one whose returns are least sensitive to the arrival of new information. However, this finding does not imply that it is socially beneficial for a bank to be highly levered. Indeed, when a bank is highly levered, the lack of a significant equity buffer can cause the informational sensitivity of the debt to increase, substantially reducing its liquidity.

The value of a security depends on the cash flows that it is expected to pay. These cash flow payments depend on the nature of the security's claims and on the issuer's ability and willingness to pay. The issuer's ability and willingness to pay in turn depend on the assets the issuer holds and the returns generated by those assets. If the payments that will be made on a security are highly sensitive to changes in the issuer's earnings or the value of the assets the issuer holds, an assessment of the security's value will require a lot of information. Such a security is said to be informationally sensitive. If a security's payments are insensitive to changes in the issuer's earnings or the value of the assets it holds, the assessment will not require a lot of information. Such a security is informationally insensitive.

Debt is informationally insensitive if the possibility of default is considered to be remote. A debt holder has a fixed claim. In the absence of default, s/he will receive the fixed amount that was promised, regardless of what the issuer's earnings are. This informational insensitivity can make debt a liquid asset. ${ }^{34}$ If the holder of the debt security needs to raise cash, he can easily sell it for its full value because the prospective acquirer knows this value. In particular, prospective acquirers need not be concerned that the seller is using superior information to take advantage of them. ${ }^{35}$

Information insensitivity breaks down when there is a significant prospect of default. In this case debt is not informationally insensitive and investors must worry about whether the issuer's earnings will be sufficient to service the debt. Such worries may lead to the debt security being illiquid, i.e., prospective buyers are so worried that the seller might have superior information

\footnotetext{
${ }^{34}$ In this discussion of the liquidity of debt, we focus on information problems and abstract from other considerations that can also play a role, e.g. legal rules about the transferability of the claims, or market coordination regarding which securities to trade. For example, it is well known that treasury securities, although they all have what are viewed as riskless cash flows, may have different liquidity characteristics.

35 See DeMarzo and Duffie (1999) for a formal model showing debt is an optimal ex-ante security design that minimizes ex-post liquidity costs for an informed seller. DeMarzo, Kremer, and Skryzpacz (2005) establish a similar result in the context of informed and competing buyers. The intuition for these results is that debt's payoff depends on the lowest cash flow realizations, whose likelihood is least impacted by new information. A related argument for the efficiency of debt is based on costly state verification, as debt minimizes expected verification costs; see Townsend (1979), Gale and Hellwig (1985). In both cases, the stipulation of a fixed payment that is to be made whenever it is feasible to do so, keeps the dependence of the security holder's claims on the issuer's earnings to the very minimum that cannot be avoided because in some eventualities, the issuer is actually unable to pay. These models, however, do not capture all of the important issues that must be considered in determining how financial institutions should be funded.
} 
that they are unwilling to buy the security at any price at which the seller would be willing to sell it. According to Gorton (2008), this is precisely what happened in the markets for mortgagebacked securities in the summer of $2007 .{ }^{36}$

Even when there is a non-negligible prospect of default, however, it is still the case that, among all the conceivable claims that might be issued to outside investors, debt is the one that is least informationally sensitive. Dang, Gorton, and Holmström (2010) argue that, since any other security that might be issued would be more likely to induce securities markets to break down because of adverse selection, maximal debt finance is socially desirable.

We are not convinced, however, that this conclusion generalizes beyond their specific theoretical model, which neglects the possibility that different investors have different needs for liquidity. For suppose long-term investors do not care about the interim marketability of the securities they acquire, whereas short-term investors do. Then, because equity creates a buffer against the prospect of default, issuing equity to long-term investors reduces the information sensitivity and enhances the attractiveness of debt to short-term investors. By issuing equity as well as debt, the bank can exploit differences in investors' need for liquidity of the securities they buy.

In the real world of course, unlike the Dang-Gorton-Holmström model, we do see banks issuing equity as well as debt. Moreover, this equity is traded on active markets, which in normal circumstances tend to be highly liquid. The existence of these markets themselves may contribute to solving the information sensitivity problem for debt. Given the high degree of information sensitivity of equity, investors in bank shares make sure to acquire information about the banks. This information is reflected in share prices. Because the prices are publicly observable, this is likely to reduce the information sensitivity problem of debt.

\subsection{Does Debt Provide Necessary Market Discipline?}

"Debt is valuable in a bank's capital structure because it provides an important disciplining force for management.” (Squam Lake Report (French et al. 2010, p. 55).)

Statement: "Debt, as a hard claim that must be periodically renewed, is necessary to provide market discipline that enhances corporate governance and prevents bank managers from taking excessive risk or mismanaging the firm.”

\footnotetext{
${ }^{36}$ The notion of market breakdown considered here is of course nothing but Akerlof's (1970) famous "lemons problem."
} 
Assessment: While correct in some specialized theoretical models, this statement is false because the models on which it is based are inadequate for the purpose of the discussion of capital regulation. Debt finance actually generates and exacerbates governance and agency problems, and these problems can be quite severe. Moreover, the mechanisms that allow debt to deliver discipline do not actually work well for large financial institutions, and/or they are extremely costly as they depend on fragility and default. Debt is also not unique it its ability to provide discipline; alternative mechanisms exist that allow equity capital to be increased without sacrificing the potential governance benefits of debt. Finally, discipline by debt holders did not appear to be effective in the events leading up to the financial crisis of 2007-2008.

A central problem of corporate governance is to ensure that the outside financiers of firms (including banks) can expect to get appropriate returns. This problem is difficult because management has control over the company's activities and has better information over what is going on. With a bank, the difficulty is compounded by the fact that certain assets, e.g., loans to small businesses, are particularly opaque and difficult to assess from the outside. Other assets may be much easier to assess because they can be traded in liquid markets, but then, this very tradability provides managers with the scope for reshuffling the bank's positions quickly, to their own personal advantage and, possibly, outside investors’ disadvantage. ${ }^{37}$

For non-financial firms, the most important governance concern seems to be about management wasting resources for their own private benefits or for empire-building. For financial firms, concerns about theft and concerns about risk management play a much bigger role. Given the ease with which financial assets can be moved around, theft is a major problem unless there is suitable surveillance ensuring that assets are not diverted; the Madoff case has just been the latest example. Surveillance prohibiting theft, however, might be easier than surveillance concerning excessive risk taking. Given the difficulty of assessing risk (even ex post), the ability to amplify risk via leverage, and the ease with which risk can be transformed through trading activities, it is crucial that managerial incentives be properly set.

The problem of excessive risk taking is compounded by the fact that it may be supported by shareholders. Equity holders have no interest in disciplining it and might even be complicit in undermining mechanisms to do so. ${ }^{38}$ As already mentioned in Section 4.2, the presence of debt creates incentives for management, acting on behalf of shareholders, to engage in strategies that

\footnotetext{
${ }^{37}$ Opaqueness as a natural by-product of the bank's own activities in monitoring its loan clients is discussed in Diamond (1984), while the "paradox" of asset liquidity as enhancing transparency while expanding the scope for manipulations by bank management is the subject of Myers and Rajan (1998). More generally, models where debt contracts emerge as optimal are more appropriate for describing why the banks themselves structure their financing the businesses they loan to in the form of debt contracts. (Such models are sometimes called "costly state verification” models.) As we argue, these models do not imply that debt or high leverage are optimal as the way to finance the banks themselves, particularly in the context where such leverage produces systemic risk.

${ }^{38}$ Bolton, Mehran and Shapiro (2010) develop a model that includes shareholders, debtholders, depositors and an executive in which this problem can be seen. They propose debt-like compensation schemes that might be helpful.
} 
yield high returns when successful and negative returns when unsuccessful, increasing the likelihood and the extent of distress and insolvency. ${ }^{39}$ Given the fixity of their claims, debt holders do not participate in the high returns in the event of success, but are burdened with the increased risk and increased cost of default (or, to the extent they are bailed out by the government, the burden will be shared with taxpayers). In contrast, shareholders benefit from the high returns in the event of success but do not suffer from the increase in insolvency costs, since their liability is limited. The same is true of managers who are compensated based on equity holder returns. The phrase "heads, I win, tails, the creditor or the taxpayer loses" captures the essence of a problem that has led to many banking crises of the past. ${ }^{40}$

With non-financial firms, the governance problem of excessive risk-taking is not so severe. First, because overall leverage is much lower, incentives to engage in excessive risk taking are generally much weaker. Second, debt holders impose restrictive covenants, monitor these covenants and intervene if the covenants are broken. Quite often, these debt holders are financial institutions with significant holdings so that there is no question about their incentives (and ability) to engage in the requisite monitoring activities.

With banks, matters are different. First, their leverage is much higher. Second, their debt holders tend to be more dispersed so that the public-good aspects of management discipline generated by monitoring are more important. Third, depositors who are insured do not have an incentive to spend resources on monitoring anyway. These features of bank finance reflect the fact that bank deposits provide an important "money like” transactions function in the economy, with many small depositors caring about the convenience of having funds available for transactions and being unable or unwilling to engage in effective monitoring. Fourth, bank creditors whose claims are implicitly guaranteed by the government, e.g. creditors in "too-big-tofail” institutions, also have reduced incentives to monitor.

The literature on corporate finance and corporate governance and the literature on banking have extensively studied the impact of different means of financing on these governance problems. These literatures have identified potential governance benefits associated with debt financing, and some people cite these benefits when arguing against significant increases in equity requirements.

\footnotetext{
${ }^{39}$ Bhagat and Bolton (2010), and Bebchuk, Cohen and Spamann (2010) show that incentives created by executive compensation led to excessive risk-taking by banks in the years leading to the financial crisis. Bebchuk and Spamann (2010) propose regulating bankers’ pay in light of this problem.

${ }^{40}$ On excessive risk taking, see Jensen and Meckling (1976), Stiglitz and Weiss (1981); in the context of banking, disastrous examples are provided by the German banking crisis of 1931 (Born 1967, Schnabel 2004, 2009) and the American Savings and Loans Crisis of the eighties (Dewatripont and Tirole 1994, Kane 1989, and White 1991). In the latter crisis, the deregulation of the early eighties permitted gambling for resurrection by institutions that would have been declared insolvent if fair value accounting had been properly applied. Haldane, Brennan, and Madouros (2010) argue that observed increases in ROE are not necessarily a measure of increased value brought about by banks, but are more likely the result of risk taking strategies by banks. This is consistent with the suggestion that "risk shifting" is a significant problem in highly leveraged financial institutions.
} 
In this section, we discuss the main arguments regarding the disciplining role of debt in the context of banking. We distinguish two main lines of arguments:

(i) that the hardness of the claim held by debtors imposes discipline on management and prevents waste;

(ii) that, with debt finance, the threat of non-renewal of funds eliminates moral hazard, including management taking excessive risks.

In each case, we find the argument that debt is capable of providing governance benefits, let alone uniquely capable of doing so, suspect. Too little attention is paid to the fact that debt finance generates substantial governance problems of its own and that the problem of excessive risk taking or "risk-shifting" is more serious the more highly leveraged the institution is. Too little attention is also paid to the fact that the presumed benefits can also be provided by other devices when equity capital levels are increased. Finally, we note that the experience of the recent financial crisis does not support the case that debt provides effective discipline for banks.

\section{Does Debt Provide Discipline Against Management Misbehavior?}

"Capital requirements are not free. The disciplining effect of short-term debt, for example, makes management more productive. Capital requirements that lean against short-term debt push banks toward other forms of financing that may allow managers to be more lax.” (Squam Lake Report (French et al. 2010, p. 44).)

"Equity investors in a bank must constantly worry that bad decisions by management will dissipate the value of their shareholdings. By contrast, secured short-term creditors are better protected against the action of wayward bank management.” (Kashyap, Rajan and Stein (2008)).

From a corporate governance perspective, debt holders have the advantage that their claims are fully specified in advance. Thus, as long as the bank is able to satisfy these claims, what debt holders are paid is independent of how the bank is doing in its business, so that debt is informationally undemanding. When the bank is doing well, debt holders need not worry much how the bank's management behaves or whether the management's business reports are to be trusted. By contrast, outside shareholders have many reasons to worry. For example, they must worry whether management might be diverting funds to its own personal benefits, e.g., by spending excessive amounts on golf tournaments and corporate jets as occurred at RJR Nabisco. This so-called "free cash flow" problem can be particularly severe in mature companies whose 
managers may find too few profitable investment opportunities in their own area of expertise and therefore look to diversify into other areas. ${ }^{41}$

These considerations seem to support the notion that, because debt is a hard claim, the governance problems associated with debt finance might be less serious and less costly than the governance problems associated with equity in reducing monitoring costs and making sure managers operate the firm as efficiently as possible. However, the conditioning statement " $a$ s long as the bank is able to satisfy these claims" in the preceding paragraph hides the fact that debt finance in fact generates and exacerbates frictions and governance problems that are potentially even more serious and harder to alleviate than the governance problems that might be associated with equity finance. Because of the limited liability of equity, debt gives rise to potential default and insolvency. If default is likely or, worse, if default has already occurred, the suggestion that debt is informationally not very demanding is clearly false. In such an event, sorting out the borrower's assets and determining what the lenders get is quite costly and may require very large amounts of resources. ${ }^{42}$ Also, and most importantly, as already mentioned in Section 4.2 and in the introduction to this section, the presence of debt creates incentives for excessive risk-taking. The problem of excessive risk-taking is the more pronounced the more highly leveraged the firm is. It is particularly serious for banks with their extraordinarily high leverage.

The assessment that debt is valuable because it imposes discipline must therefore be viewed in proper context. Whereas the Squam Lake Report points to potential positive incentive effects of debt finance, it ignores the potential negative incentive effects. A proper analysis must consider the tradeoff between them. Along these lines we observe that non-financial firms, faced with the same tradeoff, routinely choose substantially lower levels of leverage than financial firms, yet we know of no evidence that they are more poorly governed. ${ }^{43}$

We also question whether the so-called "free cash flow" problem, which focuses on management's ability to withhold cash from shareholders and engage in wasteful investment, is the primary governance problem to which banks are exposed. In fact, the governance problem that is often alluded to when discussing financial firms in the popular press is not one that debt may solve. Rather, it is the problem of excessive risk taking, which is exacerbated with leverage.

Finally, it is not clear why debt is or should be uniquely capable of providing managerial oversight for financial institutions. Fundamentally, managerial incentives are driven by

\footnotetext{
${ }^{41}$ On debt as a device to mitigate diversion of company resources for the private benefits of management, see Jensen and Meckling (1976) and Hellwig (2009a). The notion that debt is informationally undemanding is discussed by Townsend (1979), Diamond (1984), Gale and Hellwig (1985), Gorton and Pennacchi (1990), and Dang, Gorton, and Holmström (2010). Debt as a solution to the free-cash-flow problem is discussed by Jensen (1986, 1989, and 1993).

${ }^{42}$ Beyond direct costs, there are generally significant indirect costs of financial distress and bankruptcy due to operational disruptions, as well as significant social costs imposed upon outside parties.

${ }^{43}$ On average, U.S. non-financial firms have maintained more than $50 \%$ equity historically.
} 
compensation and retention schemes. Capital structure appears to be a rather crude instrument to provide such incentives, and one fraught with socially costly indirect consequences. If managerial oversight is the main motive for high bank leverage, then we would argue that policy makers should focus attention on supporting improved or alternative governance mechanisms, rather than continue to rely on the use of socially-costly high levels of leverage.

As an example of one possible mechanism, consider the proposal of an Equity Liability Carrier (ELC) for financial institutions, introduced by Admati and Pfleiderer (2010). The structure is illustrated in Figure 3.

Figure 3: Increasing Cushions through a Separate Equity Liability Carrier

Financial Institution Equity Liability Carrier

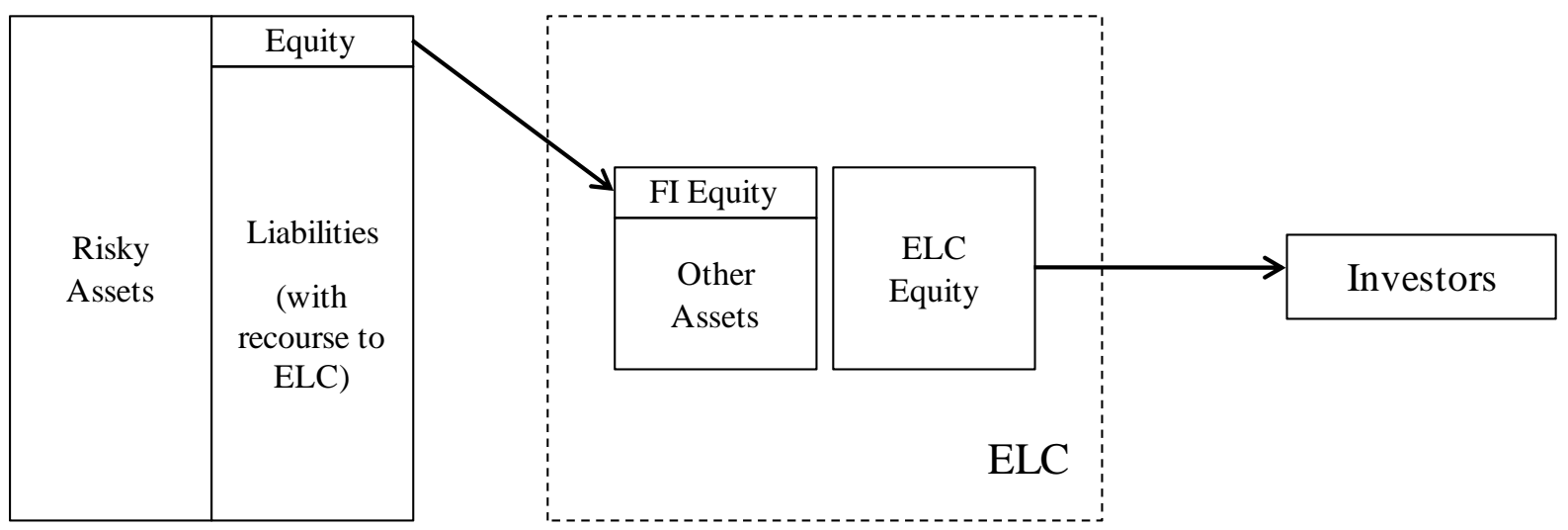

Under the ELC, existing bank equity, along with additional equity capital associated with increased requirements, are held in a separate holding company with governance that is independent of the bank itself. While the bank's creditors have recourse to the ELC assets, bank managers do not. ${ }^{44}$ In this way, bank managers continue to operate under the "discipline" of high leverage, but the ultimate costs of a default are largely absorbed by the ELC. As owners of the bank's equity, the ELC board and its shareholders have a vested interest monitoring and ensuring the bank is efficiently managed (and given their exposure to the bank's liabilities, they will guard against risk-shifting as well). As explained in Section 7 below, there is no reason that such a structure, or for that matter additional equity held directly by banks, would have a meaningful impact on the portfolio holdings of final investors.

Other mechanisms are surely possible. Rather than rely on mandatory interest and principal payments to provide discipline, well-capitalized banks could, for example, commit to a level of equity payouts, which, if not maintained, would trigger a shareholder vote to replace incumbent

\footnotetext{
${ }^{44}$ Note that the equity of the financial institution is not held publically. Instead it is held by the ELC. The ELC is $100 \%$ financed by equity that is publically held by investors.
} 
management. Such a mechanism would seem to provide virtually equivalent discipline without the costs of leverage, unless the commitment mechanism could be easily undermined by management. ${ }^{45}$ In that case, government policy could and should be directed toward strengthening corporate governance practices to allow for such commitment, rather than continue to allow high leverage.

\section{Does the Threat of Non-Renewal of Debt Finance Provide Effective Discipline?}

"The key to the market-discipline approach is placing private parties at risk with respect to undesirable behavior by banks. The mechanism for doing so is subordinated debt... Requiring banks to maintain minimum ratios of subordinated debt relative to insured debt ... imposes market discipline on banks, and thus limits banks' incentives to take on risk. Bankers that take on excessive risk, or who manage assets poorly, will find it difficult to sell their subordinated debts, and will be forced to shrink their risky assets or to issue new capital to satisfy the discipline of private uninsured debt holders.” Calomiris (1999).

"A subordinated debt requirement entails much more market discipline because a bank must either go to the market every year to replace maturing debt or shrink. If a bank's prospects appear poor to investors, its stock price will decline and it may be unable to sell more equity. But it is not forced to shrink under these circumstances, nor will regulators necessarily force a bank to shrink.” Poole (2010).

Beyond being a hard claim, the potential disciplining effect of debt is claimed to be enhanced whenever debt contracts, even long-term debt, must be repeatedly renewed. The presumption is that, in fear for their money, creditors will monitor the activities of their bank and, if they see something that they don't like, they will refuse to renew their loans. It is further assumed that management will refrain from doing anything that might annoy the creditors in order to avoid the difficulties created by a failure to have the bank's loans rolled over. Calomiris and Kahn (1991), for example, have argued that the "on demand" clause in certain deposit contracts serves to impose such discipline on bank management. ${ }^{46}$ Because depositors whose deposits are insured, have no incentives to engage in the requisite monitoring, Calomiris (1999) has suggested that banks should issue additional debt - subordinate to any deposits and crucially, uninsured - to fulfill the disciplining role that depositors fail to supply (see Calomiris (1999)). Similarly, Poole

\footnotetext{
${ }^{45}$ It is important to recognize that none of the existing literature considers such mechanisms. Indeed, any effective governance by equity holders is generally ruled out ex ante, with the objective of establishing the potential role of debt in providing discipline. That debt uniquely satisfies this role is a much stronger statement, and one that to our knowledge is completely unsupported.

${ }^{46}$ See also Diamond and Rajan (2001), where demandable debt, with the threat of a run, serves to make the banker tougher in his negotiations with the bank's own borrowers.
} 
(2010) suggests that discipline can be delivered by staggered tranches of junior, long-term debt that must be renewed, e.g. ten-year debt with $10 \%$ coming due each year.

Whereas our preceding discussion has pointed to the fact that high leverage itself provides incentives for excessive risk taking, Calomiris (in the quote given above) suggests that even this moral hazard is eliminated by debt holders engaging in monitoring so as to penalize the bank if it takes on too many risks. Calomiris and Poole both suggest that the shrinkage of the balance sheet that would result from long term debt refusing to renew the debt is a better disciplinary device than regulators can otherwise achieve. ${ }^{47}$ Note that even if one concludes that subordinated debt has some useful role to play, additional equity can still be added to the balance sheet, essentially placing it on top of the "useful" subordinated debt and other liabilities. This will reduce risk and the incentives for risk-shifting, all without reducing the disciplining function the subordinated debt might play.

At this point, however, any theory of the disciplining role of short-term (or renewable) debt must come to terms with the observation that, in the years leading up to the financial crisis of 2007-2008, there was a large expansion of short-term debt of banks. This debt finance, much of it in the form of repo contracts, was provided and repeatedly rolled over without any indication of debt holders exerting discipline. As documented by Adrian and Shin (2010), leverage at leading investment banks reached a peak towards the end of 2007, long after the crisis had broken into the open. By this time asset holdings from subprime mortgage securitization were firmly in place (i.e., the proverbial skeletons were already in the closets).

In the crisis, this short-term debt finance broke down. Short-term funding was withdrawn from conduits and structured investment vehicles in August 2007, from Bear Stearns in March 2008, and from Lehman Brothers in September 2008. These reactions did have serious consequences for the affected banks. However, given the unchecked buildup of positions prior to July 2007, it is difficult to think of these events as an instance of effective discipline of shortterm lenders over bank managers. Indeed, the breakdowns of short-term funding appeared to be driven by public information rather than information acquired by the monitoring carried out by short term lenders. The August 2007 breakdown of conduit refinancing through asset-backed commercial paper was triggered by the substantial downgrades of Mortgage Backed Securities (MBS) and Collateralized Debt Obligations (CDOs) by the rating agencies, and by the insolvencies of two Bear Stearns Hedge Funds. The breakdowns of repo refinancing for Bear Stearns and Lehman Brothers were triggered by asset price declines, in particular, in these institutions' share prices. None of these instances suggests that debt holder monitoring played an effective disciplining role of its own.

\footnotetext{
${ }^{47}$ For a recent model that attempts to model the tradeoffs associated with the disciplinary role of rolling over debt, see Cheng and Milbradt (2010). In this model equity and the manager are not distinguished, and only the maturity structure of the debt is considered; the more fundamental question of optimal leverage is not addressed.
} 
In addition to recent history, there are conceptual reasons to doubt the effectiveness of "debt renewal" as an optimal disciplining mechanism. Absent insolvency or market failure, debt can always be renewed at a sufficient yield. In that case, the only potential disciplining effect can come from the information that is provided when the debt is repriced. Any actual discipline for managers must still come through shareholders. And while there is potentially valuable information to be learned from the occasional repricing of the firm's debt, it is important to recall that the firm's equity is repriced on a daily or hourly basis, and generally provides even more information regarding the performance of the firm. ${ }^{48}$ Because debt is informationally less demanding than equity, as long as debt holders believe that the bank is going to fulfill its obligations, they don't care how the bank is doing; in contrast, shareholders always care about the extra million dollars that the bank may be earning or losing. For this reason, monitoring incentives for shareholders with respect to the problem of waste and "free cash flows" are much stronger than for debt holders. ${ }^{49}$ Moreover, debt holders may forego their own monitoring if they believe that they are protected by marketable collateral or government guarantees, or if they believe that stock prices provide enough of a clue as to where the bank is going.

Thus, debt only directly provides true discipline in the extreme scenario in which refinancing the debt is infeasible due to clear insolvency, or sufficient uncertainty regarding insolvency to induce market failure - a run on the bank. In this regard short-term debt finance also has a significant cost. The presumed disciplinary mechanism relies on uncoordinated behaviors, introducing an element of fragility into the system so that there is a positive probability of distress and inefficient destruction of asset values. Each lender's interest to be first in line if things go wrong may lead to a run taking place simply because each participant fears that the other participants are running. If the bank's assets are illiquid, such a run may result in an inefficient liquidation. The intervention of the short-term debt holders may thus impose large costs on the bank. As recent experience has shown, especially that related to the Lehman bankruptcy, there may be even larger costs for the rest of the financial system and the overall economy.

In the literature on the disciplinary role of short-term debt finance, the problem of fragility has been downplayed, even as the suggested mechanisms rely on fragility to deliver the discipline. The suggestion that short-term lenders may start a run merely because they expect others to do so, as in Diamond and Dybvig (1983), has been countered with the observation that, empirically, runs and other breakdowns of short-term refinancing are triggered by adverse

\footnotetext{
${ }^{48}$ It might be objected that share price levels do not provide direct information about the riskiness of the bank's assets, an item of concern for regulators and creditors, especially uninsured creditors. It should be noted, however, that the volatility of stock prices gives information about the riskiness of the assets. In addition, option markets exist for the publically traded equity of most large banks and option pricing reveals the market assessment of risk levels.

${ }^{49}$ Indeed, discipline from shareholders plays a potentially strong role when management incentives are linked to shareholder value; see Holmström and Tirole (1993).
} 
information and should therefore be interpreted as a way of processing that information, possibly even one that is efficient. ${ }^{50}$ In this view, fragility may be an unavoidable consequence of the fact that the debt holders' information is noisy. In other words, the possibility that a breakdown of short-term refinancing of a bank may be the result of self-fulfilling prophesies in the strategic interaction between different debt holders is not eliminated when the debt holders' behaviors are driven by their information. ${ }^{51}$ Thus, we cannot accept the view that the mechanism of market discipline by short-term debt holders is at all efficient. ${ }^{52}$

It is important to observe that fragility is essential for the disciplining mechanism that shortterm debt is presumed to provide. ${ }^{53}$ However, because of the potential inefficiencies involved in fragility, regulators often seek to avoid the socially costly consequences of fragility through bailouts or other subsidies. But while bailouts may be justified ex post, knowing that they are probable ex ante works to undermine any discipline the leverage was intended to provide. Finally, it should be observed that virtually all proposals in the capital regulation share the objective of reducing fragility, thereby in fact undermining any capability, should it exist, for fragility to impose discipline.

In sum, we do not find any strong theoretical or empirical justification for the proposition that high leverage plays a necessary, significant positive role in the governance of large financial institutions. Given that the disciplinary benefits are not apparent, are likely to be small, and potentially can be achieved in other ways, and given the large social costs of highly leveraged and fragile banks, the disciplining argument is in our view not a reason for regulators to avoid imposing high equity capital requirements. Indeed, as we noted in Section 3.1 (and as will be discussed in further detail in Section 7), additional equity can be added to banks' capital structure on top of existing deposits and any "useful" subordinated debt. Doing so will further reduce incentives for risk-shifting without sacrificing any disciplining function of such debt.

\footnotetext{
${ }^{50}$ For theoretical analyses, see Chari and Jagannathan (1987) and Jacklin and Bhattacharya (1988). For an empirical assessment, see Calomiris and Gorton (1991).

${ }^{51}$ For example, the model with multiple debt holders in Calomiris and Kahn (1991) exhibits multiple equilibria, an equilibrium with all depositors running even though information is good, as well as an equilibrium with no depositors running. In some models in which monitoring provides debt holders with private information, the equilibrium is unique, but may be excessively sensitive to the information that is available. However, in the presence of a public signal, such as the bank's stock price, equilibrium in these models may not even be unique, i.e., fragility due to multiple self-fulfilling prophesies may be an issue. See Morris and Shin (1998), Rochet and Vives (2004), Goldstein and Pauzner (2004), C. Hellwig (2002) and Angeletos and Werning (2006).

${ }^{52}$ In Rochet and Vives (2004), individual information is noisy and aggregate information is not, but the withdrawal mechanism is ill suited to provide for an efficient use of the aggregate information.

${ }^{53}$ Fragility is essential to solve the information acquisition free-rider problem among debt holders, because it provides an incentive to collect information so that they can be first in line when things go wrong, benefitting at the expense of debt holders who are later in line. The lack of co-ordination among creditors that raises the possibility of a run is thus an integral part of the mechanism.
} 


\subsection{Costs from Possible Undervaluation of Equity}

"The reason equity capital has a higher cost than other sources of funding.... is due to asymmetric information and information dilution costs .... That is, when a bank decides to raise additional equity through a seasoned offer, the market tends to undervalue the issue for the better banks.” Bolton and Freixas (2006, p. 830).

"[F]ully two thirds of the Chief Financial Officers said that they were reluctant to issue common equity when they thought that it was undervalued...”" Graham and Harvey (2002, p.16-17).

Statement: "Equity funding is costly because of costs associated with equity issuance when managers may have better information than investors."

Assessment: While information asymmetry might make the issuance of equity more costly, it does not follow that this is a valid reason to allow high leverage and to argue against higher equity requirements. First, equity issuance is less needed and is less costly when banks use less debt financing on an ongoing basis, such as would be the case if equity requirements were significantly higher. In that case retained earnings, which do not entail issuance costs and which will be more plentiful with lower debt service requirements, can be used to maintain or even grow banks' operations. Second, regulators can mitigate issue costs associated with asymmetric information by removing banks’ discretion over payout and issuance decisions.

Bankers are reluctant to issue equity when they believe it is undervalued in the market. They are also averse to selling shares when they believe equity issuance would be met with a negative stock price reaction. Such a reaction will occur if investors fear that equity is relatively likely to be issued when managers believe the bank is weak. ${ }^{54}$ Because of the negative "signaling" effect associated with issuing new shares, bank management may avoid issuing equity to meet increased capital requirements, and instead cut lending as a way to build up capital.

Note first that the negative signaling effect of equity issuance on stock prices can be neutralized by eliminating managers' discretion regarding the issuance decision. Recall that in the original implementation of the Troubled Asset Relief Program (TARP) in 2009, the government did not give large banks the choice of whether to accept government investment or not, so as to mute any information that might be gleaned from the choices made by the banks. In a similar fashion, corporate insiders eliminate negative inferences that might be drawn from their stock sales by committing in advance to selling pre-specified amounts at pre-specified times. If increased equity capital requirements are accompanied by regulation mandating that all banks

\footnotetext{
${ }^{54}$ This observation was first made in Myers and Majluf (1984) in the general context of firms raising outside capital. For a model where this effect is present in the context of banking, see Bolton and Freixas (2006).
} 
issue new equity at a pre-specified schedule, the "stigma" associated with equity issuance would be removed, and banks would not have a reason to reduce lending in order to satisfy capital requirements.

It is also very important to observe that if banks were better capitalized, they generally would have more retained earnings available to fund new investments, since they would have less to pay out in required interest payments. With higher retained earnings, banks could expand lending activity more rapidly without the need to raise external capital, which might involve issuing undervalued securities. Not only will better capitalized banks have less to pay out in required interest payments, they will also have reduced incentives to pay large dividends. This is because the more highly leveraged a bank is, the more the equity holders gain (at the expense of debt holders or those guaranteeing the debt) from a given cash payout to equity. ${ }^{55}$ The lowered incentive to pay dividends in better capitalized banks will lead to more retained earnings.

Note also that if a bank does issue equity, the cost associated with any under-pricing of equity is likely to be lower when a bank has higher capital. As we have shown in Section 3, higher capital lowers sensitivity of the value of equity to the value of the bank's underlying assets. Thus, if investors undervalue a bank's assets, the underpricing of its equity will be lower in percentage terms when the bank has more existing equity than in the case where it is highly leveraged. In that sense, managers and equity holders of better capitalized banks would find that the cost of raising external funds are not as significant as they would be if the bank were highly leveraged. $^{56}$

We also observe that, while issuing equity might be costly for the bank's existing shareholders, buying underpriced equity benefits new investors. Thus, the costs for the bank's existing investors can be mitigated simply by giving them the option to participate in the new issue through a rights offering. In this case any costs shareholders incur due to under-pricing will be offset by gains on their new holdings.

Finally, models such as that found in Bolton and Freixas (2006), which focus on the possible information asymmetry at equity issuance, abstract from the significant frictions that high leverage entails such as excessive risk taking and debt overhang. And they do not take into account the systemic risk externality that high leverage generates. As discussed above, both issuance costs and these agency costs are reduced when banks are well capitalized. These considerations, along with the fact that issuance costs are potentially reduced when banks'

\footnotetext{
${ }^{55}$ In our view (and in the view of many others), the U.S. government should not have allowed large banks to continue paying dividends while at the same time providing TARP funds to recapitalize these institutions and encourage lending. Banks in England, by contrast, were forbidden from paying dividends during this period.

${ }^{56}$ More precisely, for a given dollar amount of equity raised, the cost from underpricing will be lower with higher capital. If the bank raises both equity and debt in the same proportion as its original capital structure, then the cost from underpricing will be independent of capital structure.
} 
discretion is restricted by regulators, strongly suggest that it is inadequate to rely solely on issuance costs to argue against high equity requirements.

\subsection{Is Observed High Leverage Evidence that Equity Requirements are Socially Costly?}

"The tendency for banks to finance themselves largely with short term debt may reflect a privately optimal response to governance problems.” Kashyap, Rajan and Stein (2008).

Statement: "The fact that banks voluntarily choose high leverage is evidence that such leverage must be optimal from a contracting perspective. Attempts to limit bank leverage will therefore be privately and socially costly.”

Assessment: This statement is false. First, systemic risks, as well as tax subsidies and implicit guarantees may make high leverage privately optimal to bank shareholders and managers even when it is in fact socially suboptimal. Second, managerial compensation that is linked to ROE exacerbates the incentives to undertake high leverage. Third, because of ongoing incentives to increase leverage at the expense of earlier creditors, it is likely that observed bank capital structure itself is at least partly due to the banks' imperfect ability to precommit their own future financing choices. Such constrained "optimality," which takes as given the bank's inability to commit, does not preclude the possibility that capital regulation might lead to better outcomes even from a private ex ante perspective

There is the view that, even if we do not have a theoretical justification for it, high leverage must be efficient for banks simply because that is the capital structure that banks have chosen. While this "revealed-preference" of banks for high leverage is clear, the fact that banks are highly leveraged does not mean that regulation cannot improve over this outcome from a social, or even a private, perspective. As we show below, the mere existence of high leverage in financial institutions cannot be regarded as evidence that this outcome is privately or socially desirable. As we observed in Section 4, there are reasons, such as taxes and implicit guarantees, that banks find debt an attractive form of financing. High levels of leverage could simply be the optimal response to these subsidies. ${ }^{57}$ More generally, if default on debt involves external costs that are not borne by the contracting parties - i.e. the bank, its managers, or its outside financiers - then private contracting will lead to an excess of debt finance relative to what is desirable from

\footnotetext{
${ }^{57}$ Hanson, Kashyap and Stein (2010) argue that competition among banks pushes them to reduce funding cost as much as possible, and this drives them to be highly leveraged. In our view the main reason that leverage reduces banks' funding costs is because it allows them to take greater advantage of government subsidies associated with debt. In a model with competition, most of these advantages would be passed on to borrowers, but this does not justify high leverage, which is socially costly. As noted in Section 4.1, if the government wishes to subsidize the banks' borrowers, it should do so directly, and not indirectly through subsidies to bank leverage.
} 
a social point of view. Because banks have a private incentive to increase leverage in order to take advantage of subsidies, and because banks do not account for the negative externalities their own leverage creates, we cannot use their choice as a measure of the socially optimal level of bank leverage. ${ }^{58}$

The "revealed-preference” argument is also central to Gorton's (2010) account of mortgage securitization as a way of transforming informationally sensitive individual mortgages into informationally insensitive - and therefore highly liquid - marketable securities, which is deemed to be socially desirable because the economy has a great need for liquid securities. Gorton's assessment, too, suffers from a neglect of external costs and misaligned incentives. The negative effects of securitization on the originating banks' incentives for initial creditworthiness assessments are neglected, as are the negative effects of too-big-to-fail policies on the investing banks' incentives to impose discipline on the issuers of the mortgage-backed securities.

While it is clear why observed bank leverage is not socially optimal, it is tempting to presume that it is at least privately optimal from the perspective of bank managers and investors. This presumption, however, is unproblematic only if these financing patterns are committed to ex ante, before the bank is set up. If, at that time, all the prospective participants, present and future financiers, agree on a complete contract and can foresee all contingencies, the result can be presumed to be privately optimal. In practice, however, financing is determined by an ongoing process, with new contracts being concluded all the time. In this setting, there are reasons to believe that observed financing structures are not privately optimal, and that the extent of debt finance can be excessive even from the perspective of the participants themselves.

The basic problem is that new financing decisions affect the return prospects of incumbent debt holders and shareholders, i.e., they have an "external effect" on existing claim holders. These effects may be positive or negative in principle, but since managers who have incentive contracts that are based on equity performance typically make the decisions, decisions that cannot be committed to in advance would typically benefit equity and dilute the value of existing debt. ${ }^{59}$ For example, if incumbent debt holders do not have strong defenses against a dilution of their claims by new borrowing, the bank's management may have excessive incentives to engage in such borrowing. ${ }^{60}$ We may presume that incumbent debt holders do as much as they can to

\footnotetext{
${ }^{58}$ In this regard a better benchmark for optimal leverage in the absence of subsidies may be real-estate investment trusts (REITs), which do not enjoy tax benefits from leverage nor are candidates for bailouts in the event of default. Historically, REITs have typically maintained equity capital in excess of 30\%. (See Ooi, Ong and Li, 2008.)

${ }^{59}$ Positive external effects are to be expected if the inflow of new money enhances the bank's prospects and saves the bank from an imminent default, and negative external effects are to be expected if the claims of the new financiers dilute the positions of the incumbents.

${ }^{60}$ This agency problem associated with debt, that equity holders have an incentive to take advantage of existing debt holders by diluting the value of their claim, is discussed in most corporate finance textbooks; see e.g. Berk and DeMarzo (2010). For a specific model, Bizer and DeMarzo (1992) demonstrate that even if existing debt holders have seniority, borrowers have an incentive to issue junior debt that reduces the value of senior debt by lowering its
} 
protect themselves against such dilution by introducing appropriate covenants when they provide their funds to the bank. However, to the extent that such covenants are not complete, there is always a risk that the covenant has a loophole that provides room to engineer such a dilution anyway. Given these risks, observed market outcomes may involve too much use of contracts that dilute previous financiers' claims relative to what would be privately optimal under perfect commitment.

Furthermore, once a bank is over-leveraged, either due to possible exploitation of existing debt holders as noted above, or from an adverse change in asset values due to market conditions, there are strong incentives for it to remain that way. Reducing leverage by issuing equity would improve the value of the bank's debt, thus transferring resources from equity holders to debt holders. This so called "debt overhang" problem is a strong deterrent against raising new equity capital. ${ }^{61}$ The fact that managers and equity holders prefer to raise additional funds using debt rather than equity can be viewed as another manifestation of the risk-shifting incentive of shareholders discussed in Section 5.1. Whereas a new equity issue at this time would force the shareholders to accept a dilution of their positions as a way of bearing the loss, they avoid the dilution by gambling on, hoping to improve their position if the gamble succeeds.

The problem of moral hazard in ongoing financing relations also concerns dividend policies. If a bank is highly leveraged, the bank's shareholders — and the bank's managers as well have strong incentives to have earnings paid out, rather than retained, since if earnings are retained there is the possibility that they will be used to satisfy the claims of the debt holders in financial distress. As a further manifestation of the debt overhang problem, the bank, by maintaining high payouts, effectively under-invests relative to the policy that would be chosen by a less highly leveraged bank.

Another reason it may be difficult for banks to reduce leverage arises if prospective new shareholders are worried that they don't know enough about the skeletons that the bank may still have in its closets. In that case, as discussed in Section 5.2, a new equity issue is likely to be perceived as an indication that the value of the assets of the bank is known by managers to be low. In this case they may insist on a low share price, too low perhaps to meet the incumbent shareholders' demand that their positions not be diluted. Absent a mandatory requirement to recapitalize the firm, bank managers are likely to be reluctant to do so for fear of such underpricing.

credit quality. The equilibrium level of leverage can then be well in excess of the ex ante optimum. A manifestation of the same problem, due to lack of commitment about the maturity structure of debt, is key to results in Brunnermeier and Oehmke (2010), who show that banks have an incentive to shorten the maturity of claims to "preempt" existing creditors. Thus, banks may have too much short-term debt relative to the ex ante optimum.

${ }^{61}$ For the "debt overhang" problem of shareholders fearing that returns to new investments will be captured by debt holders, see Myers (1977). 
Another important consideration has to do with managerial compensation. Bank managers are often compensated in ways that are linked to the Return on Equity. This gives managers further incentives to choose high leverage, because this too helps magnify their compensation.

Thus, for the reasons we have outlined, high leverage is unlikely to be an optimal solution to a contracting problem, from either a social or private perspective. Banks have strong incentives to maintain high leverage to exploit both tax and distress-related subsidies, and ignore any systemic risk this leverage creates. Moreover, absent the ability to commit, heavily indebted banks have incentives to maintain or increase leverage and equity payouts in order to exploit existing debt holders. As a result, we should not use observed levels of leverage as an indication that increasing equity capital is socially undesirable. ${ }^{62}$

\section{Equity Requirements and Bank Lending}

"Bankers warned higher capital requirements would inhibit economic growth." The Wall Street Journal, August 30, 2010.

“[D]ouble-digit [capital] ratios will undermine lending.” (“We must rethink Basel or growth will Suffer,” Vikram Pandit, Citi CEO, Financial Times, November 10, 2010)

Statement: "Increased equity requirements would have an adverse effect on the lending decisions of banks and will inhibit economic growth."

Assessment: This statement is false. High leverage distorts lending decisions and because of this, better capitalized banks generally make better lending decisions. In particular less leveraged banks are less inclined to make excessively risky investments or to pass up worthwhile loans due to frictions associated with high leverage.

We now turn to what seems to be the biggest concern many have expressed about increased capital requirements, namely the notion that increased requirements will cause banks to cut back on lending and to charge more on the loans they make. Based on the discussion in Sections 3-5 we are now in a position to offer a detailed analysis of this issue.

Before attempting to analyze the claims that increased equity requirements would lead to a "credit crunch," we must remember that the biggest "credit crunch" in recent memory, the total freezing of credit markets during the recent financial crisis, was not due to too much equity but in fact to the extremely high levels of leverage in the financial system. In other words, credit

\footnotetext{
${ }^{62}$ This is consistent with the finding in Mehran and Thakor (2010) that bank valuation measures seem to be positively correlated with higher levels of equity capital in the cross section.
} 
crunches arise when banks are undercapitalized. If all banks have sufficient equity capital, they will have no reason to pass up economically valuable lending opportunities, and the risk of future credit crunches is reduced.

Arguments that increased equity capital requirements will adversely affect banks' lending seem to fall into two categories. In the first category are arguments to the effect that, when banks have less equity than required, they will cut back on lending. In the second category are arguments to the effect that banks' lending criteria are tied to the way they are funded and that, with a greater share of equity finance, lending criteria will be more restrictive. We examine these two types of arguments separately.

Arguments to the effect that banks cut back on lending because they have too little equity often are rooted in the belief that, with a "fixed amount" of bank capital, higher equity capital requirements can only be met by scaling back on loans and other investments. For some institutions, e.g., public banks in Germany, which have only limited access to the market, this belief may be justified, at least temporarily, while they are building up equity from retentions. However, in the absence of such institutional constraints and other frictions, it is unjustified. As noted in Section 3, higher equity capital requirements do not need to be met by scaling back on loans and other investments. Banks can in fact continue their lending without scaling back and at the same time meet higher requirements, either by substituting equity for some liabilities (as suggested in Figure 1, Balance Sheet B) or by expanding the balance sheet (as suggested by Figure 1, Balance Sheet C).

Thus, the imposition of higher capital requirements does not force banks to restrict lending. However, as discussed in Section 5, undercapitalized banks might choose not to issue new equity -- and thereby pass up valuable lending opportunities -- because doing so would (i) help creditors at the expense of shareholders (the "debt overhang" problem) and (ii) potentially send a negative signal to the bank's investors regarding its future prospects. The problem of debt overhang is particularly relevant in the transition when higher capital requirements are imposed. It is also relevant in a crisis, when losses have eaten into bank equity. There is evidence that both of these concerns played a significant role in the recent crisis, and it is the reason that governments (through programs such as TARP in the U.S.) attempted to reduce bank leverage using capital injections and asset purchases. ${ }^{63}$

\footnotetext{
${ }^{63}$ There is also a concern that, with capital requirements framed in terms of risk-weighted assets, bank loans would be most strongly affected by this scaling back. By cutting back on conventional banks loans, which carry a risk weight of $100 \%$, banks can reduce capital needs much more than by reducing their holdings of bonds or assetbacked securities that have lower risk weights. Thus, as argued by Brealey (1996) and Hellwig (2010), the current system of risk-weights used in capital regulation might itself contribute to a credit crunch. Given the experience with asset-backed securities in the crisis, the risk weights driving this diversion of funds out of lending and into marketable securities seems inappropriate and distortionary.
} 
To overcome this private disincentive to issue equity and recapitalize, the imposition of higher capital requirements should be accompanied by requirements for banks to quickly meet them by restricting payouts and issuing new equity. ${ }^{64}$ Furthermore, if a bank fails to maintain sufficient equity capital, similar mandates should be triggered. Once appropriately recapitalized, banks are positioned to invest in any new profitable lending activities that arise.

Another type of argument that increased capital requirement will lead to a contraction of lending is based on the notion that changes in capital requirements will make some loans unprofitable that were previously profitable to make. This change in profitability will, it is argued, be due to the fact that these loans must be "funded" in a different way. The change in profitability will then lead to changes in banks' lending decisions. In this context the appropriate question is not only whether better capitalized banks make different loan decisions than more highly leveraged banks, but also whether their lending decisions will be better or worse, from $a$ social perspective. In fact, we will argue at the end of this section that if banks have significantly more equity, they are likely to make more appropriate lending decisions and we can expect the cost of credit to be as low as is economically justifiable.

More appropriate lending decisions may involve reductions in some kinds of lending. Such reductions, however, while annoying to the potential borrowers, may well be beneficial to the economy as a whole. For the economy as a whole, the objective is not to have as much lending as possible, but to have as much lending as is appropriate in view of investors' willingness and ability bear risks. Excessive risk taking, as discussed in Section 5, may well take the form of excessive lending. This should be avoided.

How does the way loans are "funded" affect their profitability? Some of the discussion of this issue and the effects that capital requirements will have on banks' lending decisions appears to involve the fundamental fallacies about capital structure and banks' cost of capital that were discussed in Section 3.3. In order to avoid these fallacies one must be very careful to properly account for changes in risk when considering how loans are made and funded. As an example, consider the following assessment by Acharya, Schnabl, and Suarez (2010, p. 33) of banks using conduits and structured investment vehicles in order to invest in mortgage-backed securities without backing them by equity capital.

"We can assess the benefits to banks by quantifying how much profit conduits yielded to banks from an ex-ante perspective using a simple back-of-the-envelope calculation. Assuming a risk weight of $100 \%$ for underlying assets, banks could avoid capital requirements of roughly $8 \%$ by setting up conduits relative to onbalance sheet financing. ... Further assuming an equity beta of one and a market

\footnotetext{
${ }^{64}$ Hanson, Kashyap and Stein (2010) discuss the importance of debt overhang in potentially leading to lending contraction when banks are under-capitalized and make similar recommendations.
} 
risk premium of $5 \%$, banks could reduce the cost of capital by $8 \% \times 5 \%=0.004$ or 40 basis points by setting up conduits relative to on-balance sheet financing.

... banks earned about 10 basis points on conduit assets. ... it seems clear that conduits would not have been profitable if banks had been required to hold equity against their assets in conduits. In fact, banks would have made a loss of 30 basis points on each dollar invested. However, given that banks were not required to hold equity, they could earn a "profit” of 10 basis points."

In this analysis, the profitability of investing in mortgage-backed securities is assessed by comparing expected returns on additional investments with required returns on particular financing instruments. ${ }^{65}$ If no equity is used for refinancing, the investment earns 10 basis points over the calculated financing rates, while if $8 \%$ of the investment must be refinanced by equity, the investment falls 30 basis points short of the calculated financing rates. Of course, what is completely missing from this type of calculation is any consideration of risk. Whether a premium of 10 basis points over refinancing rates is considered satisfactory or not should depend on the amount of risk that is involved and on the premium that should be required to make this risk acceptable. In the assessment that is cited by Acharya et al. (2009), however, there is a complete neglect of the risk that the investment in mortgage-backed securities has imposed on the banks and their financiers. As we have seen in August 2007, this risk ended up being very real.

To make the fallacy involved in ignoring risk in the profit calculation completely obvious, consider the implications of this argument taken to the extreme. If one simply compares investment return with apparent financing costs to compute profitability as is done in the example above, then it follows that almost any bank and any firm can significantly increase its "profitability" by issuing debt and using the proceeds to buy the debt issued by firms with lower credit ratings. A firm with a rating of A might be able to issue debt at $6 \%$ and use the proceeds to finance investment in B-rated debt with an expected return of 7.5\%, producing 150 basis points of "pure profit." Of course, it is easily seen that this increases risk and the shareholders must be compensated for this. The true question is whether the extra 150 basis points in return compensates for the increased risk.

From a normative perspective, in a world without frictions and distortions, the decision on whether to make a particular loan or not should be independent of the bank's capital structure, i.e., on how the bank is funded. The decision should depend only on whether the excess of the loan rate over the market rate of interest for risk free securities provides the bank with a sufficient premium to make the risks associated with the loan acceptable. This latter question in turn should depend only on the risk characteristics of the loan and on the assessment of these risk

\footnotetext{
${ }^{65}$ Boot (1996) and Boot and Schmeits (1998) argue that in making investment decisions bankers use a type of "mental accounting" where they match the loans they make with particular sources of funding, and compare returns on that basis.
} 
characteristics by investors in the market. ${ }^{66}$ Neither the bank’s other assets, nor the bank's capital structure should play a role. ${ }^{67}$

The key ingredient of the analysis is the overall required return that is appropriate for the investment. The required return for the loan is determined by its riskiness as it is measured and priced in the market place of risky investments. From this perspective, the assessment cited by Acharya et al. (2010), which may well be a realistic description of how bankers would make this particular decision, appears as an instance of managers attempting to take on excessive risk at the expense of incumbent financiers, or of the taxpayers, and hoping they can enjoy the upside without needing to worry about the downside. ${ }^{68} \mathrm{~A}$ bank that invests billions of dollars in mortgage-backed securities to earn 10 basis points above commercial-paper rates is raising expected returns to shareholders. However, to do so, it must bear the associated risks - risks from borrowing short to buy long-lived securities as well as the credit risks of mortgage-backed securities. These risks burden incumbent debt holders (and the government to the extent that it implicitly guarantees the bank's debt) as well as shareholders. If markets are informed about these risks, the required rates of return on the bank's securities must adjust. Unless the premium of 10 basis points is deemed to be sufficiently high, this adjustment makes incumbent debt holders and shareholders take a loss. If markets are not informed about these risks, which may well have been the case in the situation that is described here, incumbent debt holders and shareholders will still be damaged when the risks come home, as they in fact did in August 2007.

As discussed in Section 4, it is true that increased equity capital requirements will remove some of the subsidies banks capture through high leverage, namely tax and implicit guarantees. If taking away these subsidies causes banks to lend less or to charge higher rates than is considered desirable, it may be desirable from a public-policy perspective to subsidize bank lending. If lending needs to be subsidized because it is important for the economy then, as we argued in Section 4, more targeted and less costly ways must be found to provide such subsidies than encouraging banks to be highly leveraged.

We now turn to the question of whether better capitalized banks will make better or worse lending decisions. The discussion in Section 5 suggests that, because of frictions associated with governance and information, highly leveraged banks are generally subject to distortions in their

\footnotetext{
${ }^{66}$ In the simplest mean-variance model of risk pricing, the loan's risk would be assessed in terms of its covariance with the market, and the requisite risk premium would be derived by weighting this covariance with the market price of risk.

${ }^{67}$ One may object that in practice bank loans tend to be opaque and market investors are unable to completely assess their risks and price them. This objection does not have any bearing on what should occur from a normative perspective. Indeed, it highlights the importance of understanding the criteria that the bank should be using. In the end, even if the bank does know more about the loan at the time it is originated, market investors will generally develop some understanding of the risk characteristics of the bank's loan portfolio, and will use this understanding to price the bank's securities in the market.

${ }^{68}$ This is an instance of the problem, discussed in Section 5.3, that issuing additional debt to fund new investments may be the result of a conflict of interest between equity holders (or managers) and previous financiers.
} 
lending decisions. These distortions may lead them to make worse lending decisions than they would have made if they were better capitalized, involving either too much or too little lending relative to some social optimum. First, equity holders in a leveraged bank, and managers working on their behalf or compensated on the basis of ROE, have incentives to make excessively risky investments, and this problem is exacerbated when the debt has government guarantees. ${ }^{69}$ Second, when banks are distressed, credit markets can freeze and certain loans will not be made due to a "debt overhang" problem. Valuable loans that are not made as a result of debt overhang would be undertaken if the bank were better capitalized, since in that case the value created by the loans would be captured by those who would fund it.

We have also argued that better capitalized banks, which have more internally generated funds with which to make new loans, would have less need to issue new claims and thus are less likely to have to issue undervalued equity. And it is possible for regulators to reduce the resistance of banks to issue equity or to withhold dividend payments that is due to negative market reaction to such actions. Thus, while banks might find it difficult to raise new equity if investors are suspicious that they have "skeletons in the closet," it might be possible for regulators to alleviate some of this problem by mandating new equity issuance and limiting payouts so as to enhance banks' ability to retain earnings until they build adequate cushions. In any case, this issue will not affect lending adversely once banks are better capitalized.

To summarize, under appropriately designed and significantly higher equity capital requirements, banks would be more likely to make better, more economically appropriate, lending decisions, and engage less in either too much or too little lending from a social perspective. To the extent that banks can quickly get to the point of being better capitalized (by adding equity without suffering negative consequences, as discussed in Section 5.2), there should be no concern with any negative impact on the economy of increased equity capital requirements.

\section{Increased Bank Equity, Informationally-Insensitive Debt, Asset Allocations, and Liquidity}

"Creation of information-insensitive debt is the function of the banking system." Gary Gorton (2010 p. 27).

Our discussion so far has addressed the implications of higher equity requirements for banks' funding costs and for their lending policies. We argued that, with more equity and less leverage,

\footnotetext{
69 It has been argued (perhaps with some hindsight bias) that a significant number of the loans that were made prior to the 2007-2009 financial crisis, such as some sub-prime mortgage loans, were ones that should not have been made and could not be justified by conventional lending standards.
} 
banks have fewer incentives to take excessive risks and are also less likely to be constrained by debt overhang. Any change in lending policies that is induced be higher equity requirements is likely to improve social welfare. ${ }^{70}$

A contrary view considers high equity requirements to be detrimental because the creation and marketing of debt-like securities is deemed to be one of the most important functions of the banking system, According to the above quote from Gorton (2010), the major role of the banking system in the economy is to transform informationally sensitive and therefore illiquid loans to individual clients into informationally insensitive and therefore liquid claims that are eagerly demanded by final investors. In this view, the development and expansion of securitization, as well as the expansion of the so-called shadow banking system that engaged in this business were socially useful because they served to meet the large demand for such securities, more precisely for the benefits that investors would derive from the high liquidity of these securities. As was pointed out in Section 5.4, this assessment neglects the social costs that arose from the misalignment of incentives in mortgage origination and securitization that was induced by limited liability; it also neglects the social costs that arose because the banks that invested in mortgage-backed securities counted on being too big to fail and therefore did not properly watch the risks in these securities. In this context, it is important to appreciate that some of the "need" for liquidity was due to regulation rather than economic fundamentals. Securities that were tradable in markets that were deemed to be liquid went at a premium because, under the modelbased approach to capital regulation, they did not require much equity backing. Securities that were held through institutions in the shadow banking system did not require any equity backing at all; with financing coming through asset-backed commercial paper, easy salability of the assets seemed like a good way to insure against refinancing risks. The systemic implications of the fragility that was thereby created were altogether neglected. Given these omissions and given the huge costs of the system's breakdown in the crisis, we see strong reasons to question the social value of much of this debt creation. ${ }^{71}$

At the same time, we observe that, even if the economy has a great need for deposits and other forms of informationally-insensitive debt, there is no reason why higher equity requirements should prevent banks from serving this need and providing the socially optimal

\footnotetext{
${ }^{70}$ This assumes as well that distortions in lending decisions are not created by risk-weights..

${ }^{71}$ The demand for the deposits and informationally-insensitive securities issued by a bank depends in part on the yield that the bank offers on these securities. Because banks can obtain subsidies through increasing leverage and capturing the benefits from implicit guarantees, they potentially were able to offer higher yields on deposits and informationally-insensitive debt than they would have been able to offer without these subsidies. Doing so would increase the demand for deposits and informationally-insensitive securities beyond what it would be without these subsidies. Any evaluation of demand-driven explanations for the growth of the shadow banking system must take into account the subsidies banks received and the incentives banks had to increase leverage. Considerations such as these are consistent with supply-driven factors driving the expansion. As Acharya and Richardson (2010) discuss, much of the activities in the shadow banking system can be explained by attempts to evade capital regulation and avoid deposit insurance fees. For an attempt to "size" the repo markets through the crisis, see Krishnamurthy, Nagel and Orlov (2011).
} 
amount of deposits and informationally-insensitive debt. Recall that in Section 3.1 we showed that banks need not change their deposit base or the amount of debt they have issued in response to an increase in equity requirements. Higher equity requirements can be met with no change in the banks' liabilities in Balance Sheet $\mathrm{C}$ of Figure 1. A transition from the original balance sheet to Balance Sheet $\mathrm{C}$ involves issuing new equity and using the proceeds to purchase additional assets such as marketable securities.

One concern one might have in using the Balance Sheet $C$ approach is that it might be costly or inefficient for banks to hold large positions of marketable securities that are unrelated to their core business. Among non-financial firms, however, it is common to hold cash and marketable securities. For a set of large technology firms, the size of these holdings is shown in Table 1.

Table 1: Cash Holdings of Large Technology Firms (June 2010)

\begin{tabular}{ccc} 
& $\begin{array}{c}\text { Cash and } \\
\text { Marketable Securities }\end{array}$ & $\begin{array}{c}\text { Percentage of Total } \\
\text { Value of Assets }\end{array}$ \\
\hline Apple & $41.7 \mathrm{~B}$ & $15.8 \%$ \\
Cisco Systems & $35.1 \mathrm{~B}$ & $21.7 \%$ \\
Google & $24.5 \mathrm{~B}$ & $15.0 \%$ \\
Intel & $17.3 \mathrm{~B}$ & $13.2 \%$ \\
Microsoft & $39.7 \mathrm{~B}$ & $14.7 \%$
\end{tabular}

Non-financial firms may hold these reserves in anticipation of future investment opportunities and as a precaution against bad times. The fact that they do so seemingly indicates that, at least for them, the private benefits of holding these reserves exceed the costs. If holding cushions is feasible for these non-financial firms, why can't leveraged banks also have cushions simply for the purpose of backing up their substantial debt obligations? Surely the concern that holding such securities is unrelated to core business of a bank is much less compelling than it is for non-financial firms.

From the perspective of the overall economy, one might ask whether, economically, it makes sense for banks to issue equity in order to hold marketable securities and thus to "intermediate" the holdings of securities in the economy. Doesn't this reallocation distort the structure of the overall financial system? Figure 4 illustrates the implications of expanding the bank's balance sheet using newly issued equity to acquire marketable securities. 
Figure 4: Asset holdings under current and increased capital requirements.
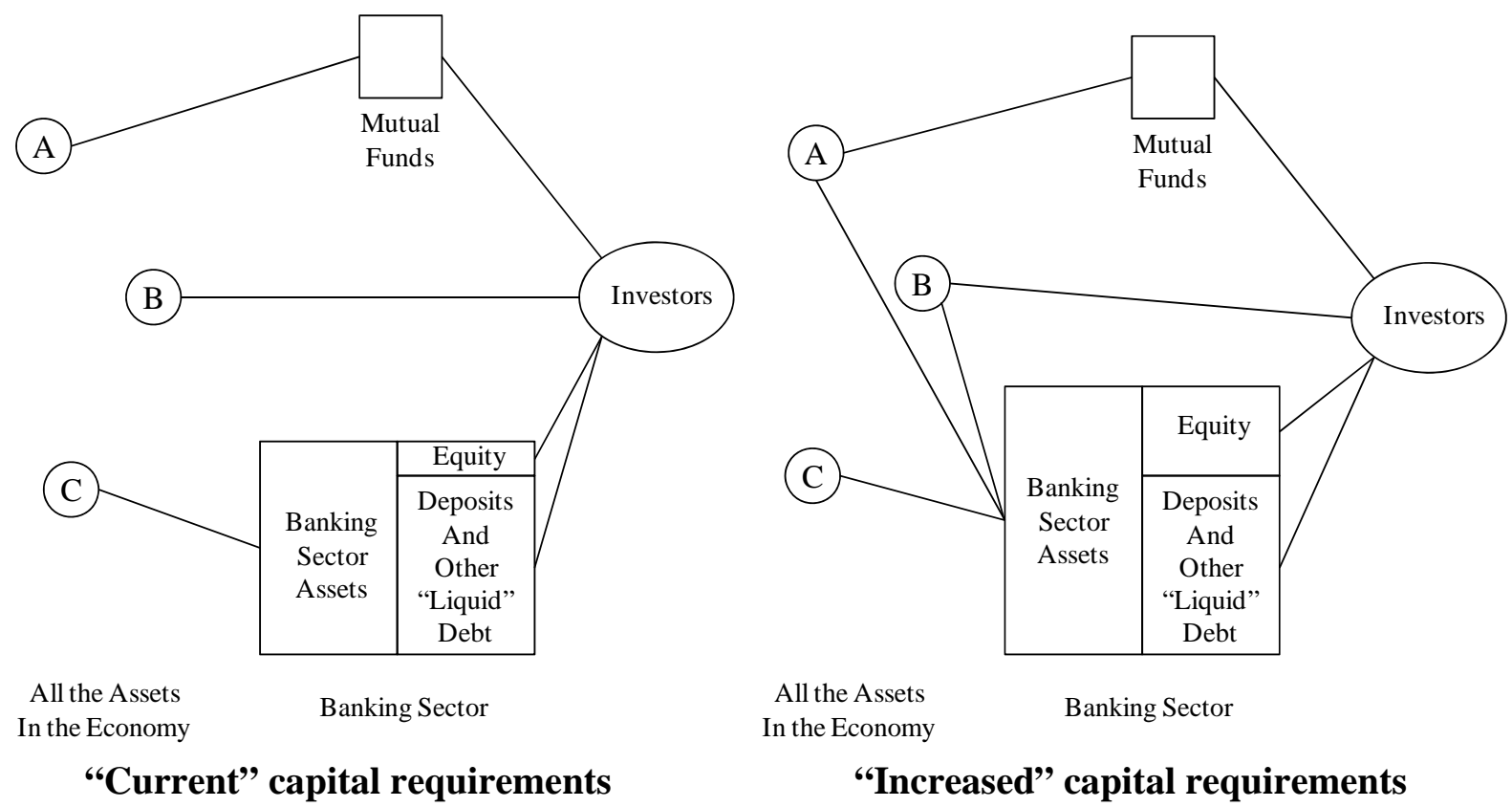

“Increased" capital requirements

The left hand side of Figure 4 depicts in a simple way how assets are held in the economy. Ultimately investors (households) hold claim to all of the assets in the economy, either directly or indirectly through intermediaries. In the figure we take the banking sector to be comprised of intermediaries who provide informationally-insensitive debt through deposits and other liquid liabilities. The banking sector holds claims on some of the economy's assets (assets which we label "C" and consist, for example, of business loans and residential and commercial mortgages) and finances these holdings by issuing equity claims and debt claims (deposits and other "liquid debt"), all of which are ultimately held by investors. Other intermediaries, such as mutual funds, ETF's, private equity funds, and hedge funds, give investors indirect claims on assets but do not do so in a way that creates low-risk, informationally-insensitive claims. The assets labeled " $A$ " are held indirectly by investors through these types of intermediaries. Finally, some assets (those labeled "B") are held directly by investors.

Now consider what happens if equity requirements are increased. Banks can continue to provide the same dollar amount of informationally-insensitive debt and deposits and, at the same time, meet the higher capital requirements by issuing equity and buying marketable securities (some combination of securities found in "A" and "B"). If the bank issues more equity to buy marketable securities, there is not necessarily any effect on the aggregate assets - or the aggregate production activities - in the economy. Some of the assets that investors held either directly or through other intermediaries are now held by investors through their holdings of claims on banks. Ultimately, directly or indirectly, all securities, representing claims against all assets in the economy, are held by final investors. The effect of moving from the left-hand side 
to the right-hand side of Figure 4 is simply to arrange the claims in a different way. Aggregate asset allocations in the economy and productive activities need not be affected. In the context of the entire economic system, expanding banks' balance sheets in this way should not change, and in particular should not prevent, the undertaking of any and all productive activities, and it also does not need to affect the risk-return profile of the holdings of individual and institutional investors. Those who hold diversified portfolios of assets still have access to the same combinations of risk and return, and the riskiness of bank equity, as modified by additional holdings, can be taken into account. ${ }^{72}$

There are, however, two major benefits of the right hand side of the figure 4 over the left hand side. First, the equity cushion of the banking sector is larger on the right hand side than it is on the left. Effectively this has redistributed liability in a crisis away from the government and its taxpayers and toward bank equity holders, reduced systemic risk, and reduced the incentives for excessive risk taking. ${ }^{73}$ Second, as we discussed above in Section 5.1, increasing equity and lowering leverage makes debt more informationally-insensitive. Because of the larger equity cushion, the bank debt on the RHS of figure 4 is, everything else being equal, more liquid and more "informationally-insensitive" than the bank debt on the LHS of figure 4.

In terms of what types of securities banks would purchase if they need to add cushions but do not have valuable loans to make note that between January 2008 and August 2010, the outstanding U.S. treasury debt held by the public increased by $\$ 2.4$ trillion. This increase alone represents almost $20 \%$ of the total value of assets held by U.S. commercial banks, which is approximately $\$ 12$ trillion. These new assets, among others, could be used to increase banks' equity by as much as $16.6 \%$. The use of marketable securities to increase the equity cushion of banks, however, does not require that all or even most of these securities be completely liquid or "safe." The addition of any security to the bank's balance sheet acquired using the proceeds of an equity issuance decreases systemic risk.

One objection to the approach taken above is that the expansion of the balance sheets of the banking sector through Balance Sheet $\mathrm{C}$, while it reduces leverage, also increases the size of banks, at least if we measure size by total assets. In light of the problems caused by banks that are "too big to fail," many have called for reducing the size of banks. ${ }^{74}$ The optimal size of banks, and the extent of scale economies in this sector, is a topic of great controversy. If scale economies justify the existence of very large banks, then making the large banks safer by

\footnotetext{
${ }^{72}$ To the extent that bank equity becomes less risky, those who would like to take on additional risk can create leverage by buying on margin, trading options in an exchange, etc.

${ }^{73}$ In a potential crisis situation, some of the value of the marketable securities acquired by the banks (assets in the "A" and B" groups) is received not by the banks' shareholders but by their creditors. The loss is borne by shareholders. From a social perspective, such an outcome is much better than a default that would have severe repercussions for the rest of the financial system. In addition, the fact that the loss is borne by the shareholders and not by creditors and the government reduces ex ante risk shifting incentives.

${ }^{74}$ See, for example, Johnson and Kwak (2010).
} 
reducing their leverage is of critical importance. The increase in size brought about by Balance Sheet $\mathrm{C}$ is then justified because it reduces fragility and systemic risk. However, nothing we said above requires that any individual bank be large or that the industry be highly concentrated. Indeed, large banks can be split up into smaller banks, each of which could meet equity requirements through Balance Sheet $\mathrm{C}$ in a way that preserves the aggregate levels of lending and liquidity provision. ${ }^{75}$

Our discussion up to this point has been exclusively focused on the costs and benefits of increasing the equity capital requirements of banks. Another important regulatory issue concerns liquidity requirements for banks. A full discussion of liquidity requirements is beyond the scope of this paper, but it is useful to make a few observations about liquidity in the context of our analysis of increased equity requirements. Much of the focus on liquidity needs of banks is related to the fragility associated with highly leveraged banks that rely on short-term funding. Liquidity problems arise when short term funding is not renewed and banks may be forced to sell assets on short notice. Liquidity is important because a liquidity crisis can lead to distress for banks that are technically solvent. For such banks a significant "reserve" of liquid assets may be prudent. Liquidity reserves become less important when banks are much better capitalized. First, even if a bank uses short-term funding, the scenarios that require liquidity (e.g. a run on the bank) become less likely when the bank is better capitalized. Second, if the bank is better capitalized, the central bank or "lender of last resort" has less reason to worry that a liquidity crisis is actually a solvency crisis. Increased equity capital thus ultimately lowers the cost of central banks providing liquidity backstops.

While we have argued that the social costs of banks using more equity to fund their operations are very small, to the extent that liquidity requirements force banks to hold cash in reserve, they would impose the opportunity cost of not receiving a higher return on those funds. Holding excessive amounts of cash, or other liquid assets whose return is low because of a liquidity premium, relative to the bank's liquidity needs is costly because the bank pays an unnecessary liquidity premium. This inefficiency can be interpreted as a social cost. ${ }^{76}$ As discussed above, however, additional equity need not be invested in cash, and it can either be put into profitable lending or invested in marketable securities that earn market-determined returns. Because increased equity requirements can potentially reduce the need for liquidity, they may provide an additional benefit of reducing the total cost associated with the need to maintain liquidity.

\footnotetext{
${ }^{75}$ We envisioned Balance Sheet $\mathrm{C}$ as a way to effect the transition to higher equity requirements. As the banking sector grows organically, banks can sell the marketable assets they acquired to finance new, socially valuable loans.

${ }^{76}$ For a formal treatment of the costs of inefficient holdings of liquid assets and the role of public liquidity provision, see Bolton, Santos and Scheinkman (2010)
} 


\section{A Skeptical View of Contingent Capital and Bail-in Mechanisms}

Contingent capital, i.e., debt that converts to equity in some scenarios, has recently been proposed, e.g., by Flannery (2002) and Squam Lake Group (French et al., 2010), as a security that regulators should encourage or perhaps require financial institutions to issue. This notion is being examined by the Basel committee as an alternative to at least some Tier 2 capital that could absorb some losses in a crisis. Related proposals involving mandatory conversion of debt to equity to help simplify bankruptcy procedures have been termed "bail-in.,77

Clearly, once a bank is in difficulties, it is important to have mechanisms that provide for "expedited resolution" without having to go through all the potential inefficiencies of an insolvency proceeding. However, while such remedies are clearly valuable from an ex post perspective, contingent capital, as a security on the bank's balance sheet, must be assessed from an ex ante perspective, and thus in the context of capital requirements for banks. ${ }^{78}$ Indeed, any regulation regarding the types of securities that are issued by financial institutions must be assessed in this more general context and assessed within all possible strategies, including increasing equity requirements.

From this perspective, contingent capital appears as a form of hybrid capital, subordinated debt that is transformed into equity when the stipulated conversion conditions are realized. As such, it has both debt-like and equity-like features. From a public-policy perspective, the question is what is gained by having this more complicated structure. If we want to enhance the bank's capital cushion, why not just require the cushion to come in the form of simple equity?

In many discussions it appears that one of the main motivations for having "debt-like" contingent capital is to preserve for the banks the tax subsidy associated with debt financing. As discussed in Section 4.1, however, preserving this subsidy is not justified from a public-policy perspective. Moreover, since contingent capital does not give debt holders legal "creditor rights," it's not clear that it qualifies as a debt security under some of the tax laws. There are many other complications that arise with contingent capital, particularly how triggers and conversion rules should be designed so as to make it an effective cushion and also prevent potential for manipulation by investors or managers, especially close to such times when the triggers are potentially reached. ${ }^{79}$ Given these and other complications, and the fact that it has not been

\footnotetext{
${ }^{77}$ On the bail-in concept see, for example, “From Bail-Out to Bail-In,” The Economist, January 30, 2010, and BIS (2010b).

${ }^{78}$ Contingent capital is often discussed in the narrow context of how regulators would handle distressed financial institutions at the time of systemic crisis. For example, in French et al. (2010), contingent capital is discussed in a chapter that is distinct from the discussion of capital regulation (and in fact these two chapters are separated by a chapter on compensation).

${ }^{79}$ An early analysis of the valuation of contingent capital claims and the impact of including such a security in the capital structure of banks, see Raviv (2004). Issues related to how triggers should be set and the potential for a "death spiral" if the conversion decision can be manipulated through short-term trading are discussed in Duffie
} 
established that contingent capital alleviates any inherent frictions, we are skeptical that going down this route is a worthwhile approach. ${ }^{80}$

Figure 5 compares creating cushions using contingent capital to doing so using simple equity instead of contingent capital.

Figure 5: Comparing Contingent Capital to Equity

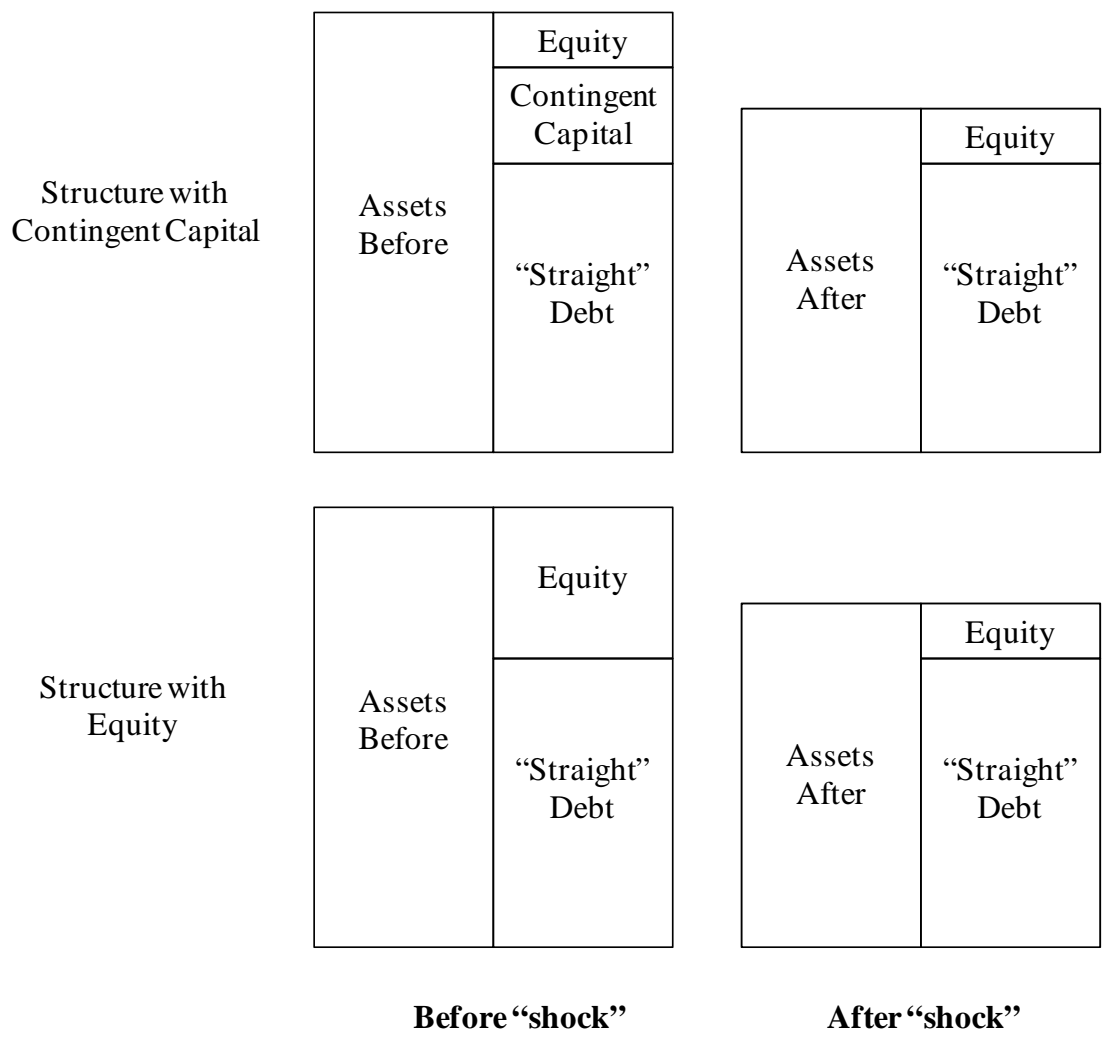

The top panel illustrates how contingent capital is meant to provide a cushion in the event of a crisis. An event that causes asset values to decline leads to the conversion of contingent capital to equity. The balance sheet before the crisis (the top left hand side) is transformed into the balance sheet on the top right hand side. In the bottom panel we trace the same development, but in this case we assume that additional equity was used to provide the additional cushion instead of contingent capital. The outcome is of course the same. The major difference is that with equity

(2010), Sundaresan and Wang (2010), and McDonald (2010). Pennacchi, Vermaelen and Wolff (2010) propose a version of contingent capital that they call COERCs (Call Option Enhanced Reverse Convertibles”), which have the feature that equity has the option to repay the debt to avoid dilutive conversion.

${ }^{80}$ A similar conclusion is reached in Goodhart (2010). 
there is no need to go through the process of mandatory conversion, and the potentially problematic process and uncertainties leading up to the actual conversion are avoided. ${ }^{81}$

The proponents of contingent capital seem to regard it as a device to resolve some of the difficulties that stand in the way of a recapitalization through the market once the bank is in difficulties. By having an automatic conversion of debt into equity, the bank may avoid the debt overhang problem described earlier, which prevents certain valuable loans from being made. If investors anticipate such a possibility, however, they would require high rates of interest on these securities as compensation for the risk to which they are exposed. (This conclusion follows from the same basic insights discussed in Section 3.3.) From this perspective, it is not clear why, apart from the banks' private tax considerations, provision of an additional cushion by contingent capital should be preferable to provision of such a cushion by additional equity. One can in fact think of equity as contingent capital that is converted $a b$ initio.

In this context, it is also useful to go back to the experience of the crisis. According to the Basel Committee on Banking Supervision (2009), one flaw in pre-crisis arrangements had been the poor quality of capital, different regulators in different countries having different standards as to which securities they treated as capital and which ones they did not. In many cases, various hybrid securities were included in Tier 1 capital, certain forms of subordinated debt in Tier 2 capital. When the crisis came, these securities did not always provide the cushion they should have provided. Indeed, some governments were afraid of domino effects of defaults and extended their bailouts to even these securities.

Relative to the various forms of hybrid securities and subordinated debt securities, contingent capital would seem to have the advantage that conversion would be automatic, without insolvency proceedings. While we share the view that insolvency proceedings are too complicated, lengthy, and costly, we are not convinced that automatic conversion would solve the problem. First, if the holders of these securities are sufficiently important, government temptation to bail them out will be no less than it was for subordinated and hybrid securities in the current crisis. Second, while the conversion itself may be automatic, when the bank is in difficulties, holders of these securities may want to sell them before the conditions for conversion arise. In other words, the attempt to smooth matters in a later stage may just pull some of the frictions forward in time.

We have seen no compelling argument that contingent capital that has a debt-like structure prior to conversion has a positive impact on governance problems sufficient to justify including it in capital regulation. The skepticism that we expressed in Section 5.1 concerning the potential

\footnotetext{
${ }^{81}$ In this figure we are implicitly assuming that the "straight debt" is safe or insured, so its value does not change from "before" to "after." If the bank had some straight debt that is not insured, then its value might decline in this transition, because the lower asset value might expose it to an actual default risk. This does not change the conclusion that the structure with equity leads to the same results as the one with contingent capital.
} 
role of debt in resolving governance problems extends to the "debt-like" features of contingent capital. In sum, in our view the case for including contingent capital as part of capital regulation has not been established against simpler approaches based on equity.

\section{Concluding Remarks and Policy Recommendations}

In this paper we have examined various claims and arguments that assert that increasing equity requirements for large banks entails significant costs. We find that these claims and arguments, when analyzed from first principles, are very weak and not compelling. Why do we hear these arguments? One possible answer is given in the table on the last page, which summarizes our analysis of the claims. We see that managers and bank shareholders have some strong incentives to maintain high leverage for banks and to resist increased equity capital requirements. In particular government subsidies that reward debt financing (and penalize equity financing) benefit managers and shareholders. These subsidies would be reduced if equity capital requirements were increased. Of course, arguments made by bankers against increased capital requirements are not automatically invalid just because it might be in their interest to oppose this stricter regulation. Rather, political and regulatory authorities should be especially skeptical when evaluating claims that are not supported by strong arguments. As we have shown above, the most important claims that are advanced in this context are based on fallacies, irrelevant facts, or insufficiently rich theories.

\section{Political economy of fallacious arguments}

The debate over capital regulation is a bit reminiscent of the battle over expensing stock options some years ago. The issue in that debate concerned inconsistencies in the treatment of employee compensation on the income statement. Whereas compensation in cash and restricted stock was recognized as an immediate expense for the calculation of earnings, employee stock options were not recognized as an expense as long as the options were not "in the money" when they were issued. When the Financial Accounting Standards Board (FASB) attempted to change this accounting treatment in 1994 by requiring that options be expensed in a way that reflected their true cost, a fierce political battle ensued.

Opponents of option expensing made three types of arguments. The first was that a company incurs no cost in granting executive stock options when they are issued, since the options are not in the money. Of course, this statement is simply fallacious. The second statement that was often made was that executive options are difficult to value with precision. But while this statement is true, because the value of these options depends, for example, on the difficult to model exercise decisions of employees, it is basically irrelevant. Just because the options are difficult to value does not mean that valuing them at zero is appropriate. ${ }^{82}$ The third argument made against

\footnotetext{
${ }^{82}$ In fact, companies often value complex liabilities, such as health care costs of retirees, in preparing accounting statements.
} 
expensing options asserted that expensing options would have a real and negative impact on the economy, by somehow preventing entrepreneurial firms from obtaining financing, which would impede growth and reduce the competitiveness of the U.S. economy. These assertions were ultimately based on some form of investor irrationality, since they implied that investors would be misled by changes in accounting rules even though these changes had no effect on the underlying economics of the firm.

All of the above arguments were made at various times, but of course it was the claims about the "real" effects of expensing options that were most effective with politicians. In fact, in 1994 the U.S. Congress threatened to dismantle FASB unless it backed off from the plan to expense options. A decade later, after World Com, Enron, and other corporate scandals, it suddenly became politically palatable to expense options, and FASB went ahead to change the rules with minimal objections from Congress. And the result? There has been no evidence that this change in accounting rules had any negative economic impact whatsoever.

Quite similarly, as we have discussed, the arguments against high equity capital requirements fall under the same three categories: those that are fallacious, those that are true but irrelevant, and those that are unpersuasive. Because the social benefits of significantly reducing bank leverage are significant, and because there are no significant social costs of increasing equity requirements for banks, politicians and regulators should not be overly concerned with threats that credit markets will be adversely affected by increasing equity requirements. High equity requirements need not interfere with any of the valuable intermediation activities undertaken by banks. Regulators should therefore take steps to impose significantly higher equity requirements as quickly as possible.

\section{How high should equity capital requirements be?}

Given the above assessment, what is the appropriate equity capital requirement? Various empirical studies, e.g., BIS (2010a), Bank of Canada (2010), and IIF (2010), have attempted to answer this question using a variety of models to estimate the costs and benefits of increased equity requirements. Going through the different empirical models that are used in these documents is beyond our scope here. However, it appears that the methods of analysis used in most of these studies fall prey to many of the concerns we have identified in this paper. For example, in BIS (2010a) the analysis uses a fixed estimate for the cost of equity that is based on historical averages, ignoring the fact that decreased leverage would necessarily lower the risk premium on equity. Moreover, the approach in most of these studies assumes that if bank margins or ROE decline, or bank taxes increase, these effects translate to social costs, which is incorrect. Calculations of the benefits of increased equity requirements in these analyses also do not take into account potential improvements in the quality of lending decisions that better capitalized banks are likely to make. While some of these might be hard to measure, we suspect that upon closer examination the net social benefits of increased equity requirements have been 
under-estimated in these studies. This under-estimation might be quite substantial if, as we have argued, the social costs are significantly over-estimated. ${ }^{83}$

To attempt to give even a rough, order-of-magnitude answer to the question of what appropriate equity requirements should be, one must in principle refer to how capital ratios are calculated, something that we have not addressed in this paper. While important institutions have vaunted themselves as having $10 \%$ core capital relative to risk-weighted assets under Basel rules, this measure has often meant only $1 \%$ to $3 \%$ capital relative to the overall balance sheet (i.e., unweighted assets). The notion of using risk-weighted assets for capital regulation is based on the fact that the riskiness of the assets should in principle guide how much of an equity cushion is prudent for regulators to require. In the recent financial crisis, however, we have seen that assets that had zero risk weights in the banks' models could suddenly experience severe problems. ${ }^{84}$ Any system of capital regulation must come to terms with these issues.

Leaving aside the issue of how one accounts for the riskiness of banks' assets, and taking as a benchmark current levels of risk, one can discuss capital requirements in terms of unweighted equity ratios, i.e., equity capital relative to total assets (off-balance sheet as well as on-balance sheet) held by the bank. Historical comparisons (e.g., evidence provided in Alessandri and Haldane (2009)) suggest that equity capital ratios as high as $20 \%$ or $30 \%$ on an unweighted basis should not be unthinkable. Another benchmark can be gleaned by considering Real Estate Investment Trusts (REITs), which do not enjoy tax benefits from leverage nor are they candidates for bailouts in the event of default. According to Ooi, Ong and Li (2008), REITs typically maintain equity capital in excess of $30 \%$ of assets. Based on all of these observations, equity capital ratios significantly higher than $10 \%$ of un-weighted assets should be seriously considered.

Given appropriate systems for tracking the systemic risks of important financial institutions, regulators can use their judgment to adjust the equity requirements of all banks according to economic conditions, possibly using tools such as payout restrictions and mandatory equity

\footnotetext{
${ }^{83}$ Kashyap, Stein and Hanson (2010), who also point out fallacies associated with not adjusting required returns to the reduced riskiness of equity that results from higher equity requirements, focus on the legitimate concerns related to regulatory arbitrage and shadow banking, which we mention below. However, in their estimate of the impact of increased equity requirements on lending costs, they still take the tax code as given, neglecting the fact that such transfers are not themselves a social cost. As discussed in Section 5.2, we also take issue with their recommendation that regulators give banks significant time to adjust to higher equity requirements due to information asymmetries and the "stigma" associated with equity issuance. Instead, we recommend payout restrictions and possibly mandatory equity issuance that in fact alleviate these problems and accelerate the capitalization process.

${ }^{84}$ Given this experience, Hellwig (2010) has suggested that the notion of measuring risks is itself quite an illusion and that in practice the risk-calibration approach provides banks with too much scope for manipulating their models so as to "economize" on equity capital by not recognizing risks.
} 
issuance, in a manner analogous to the use of margin requirements by financial exchanges to maintain the safety of transactions. ${ }^{85}$

\section{The transition to higher equity capital requirements}

How would banks get to the point of having much larger equity cushions? Should they be given many years to build up their equity capital? It is widely argued, and recent policy proposals recommend, that banks be given a very long time to adjust to new capital requirements. Kashyap, Stein and Hanson (2010) based their recommendation on the claim that, as suggested in Myers and Majluf (1984), equity issuance might be costly if investors fear that managers issue equity only when it is overpriced, which may make banks reluctant to issue new equity to satisfy capital requirements. We have suggested, however, that this problem can be alleviated if regulators actually remove some of the discretion that banks might otherwise have with respect to equity issuance, thereby eliminating the stigma associated with it. By setting schedules for banks so that they must issue equity at specific times, investors will no longer be justified in making negative inferences about any particular bank based on the fact that it is issuing equity. As we noted, this approach is similar to what the U.S. Treasury did when forcing all large banks to accept Troubled Asset Relief Program (TARP) funds so as to remove any stigma associated with taking the funds.

Our discussion produces another clear-cut policy recommendation, which provides an efficient way to increase equity cushions. Whatever is the target equity ratio, and, again, we believe it should be significantly higher than current policy debate suggests, we urge regulators to prohibit banks, for a period of time, from making any payments to equity. This restriction would force banks to retain earnings as they build their equity capital. Paying dividends, particularly in a situation of distress or when leverage is high, is in fact one of the ways in which the conflict of interest between equity holders on one hand and debt holders or the government on the other manifests itself, since by paying dividends, equity is able to withdraw funds which might otherwise be used to pay debt. There is evidence that equity payouts, at least in the U.S. exacerbated the recent financial crisis. ${ }^{86}$ If done under the force of regulation, withholding dividends would not lead to any negative inference on the health of any particular bank. ${ }^{87}$

\footnotetext{
${ }^{85}$ Hart and Zingales (2010) propose that regulators use market information to determine when to force banks to recapitalize. As mentioned in Duffie (2010), regulators might be able to force banks to increase equity capital through mandatory rights offerings.

${ }^{86}$ Banyi, Porter and Williams (2010) document an increase in stock repurchases by U.S. financial institutions prior to 2007, including specifically those who later received TARP funds. According to Acharya, Gujral, and Shin (2009), large U.S. banks paid \$130 billion in dividends during 2007-2008, years in which they were in distress and where most were also being provided with additional funding from the government Rosengren (2010) also points out that regulators should ban equity payouts in a crisis situation. Acharya, Gujral, and Shin (2009), Acharya, Mehran and Thakor (2010) and Goodhart et al (2010), suggest that regulators use restrictions on dividends as part of prudential capital regulation.

${ }^{87}$ Note that banks' stock prices will likely fall as a result of implementing such policies because current prices reflect the value of government subsidies as well as shareholders' ability, absent such dividend prohibition, to generate cash payout on a regular basis without too much concern about the solvency of the bank. Forcing banks to
} 


\section{Equity capital requirements and "regulatory arbitrage" through the shadow banking system}

In public political discussions, bankers and others frequently use arguments against higher capital requirements that do not directly address the merits of such requirements, but are based instead on issues concerning the enforceability of higher requirements. Specifically, warnings are frequently made that financial activities will move out of the regulated part of the financial system and into the unregulated part, the so-called shadow banking system. Given that institutions in the shadow banking system may have hardly any equity at all, such a development would increase the overall fragility of the financial system.

It might appear that the experience of the financial crisis gives some weight to these arguments. For example, financial institutions from Continental Europe used conduits and structured-investment vehicles located in Ireland or in New Jersey, i.e., shadow banking institutions in other jurisdictions, in order to invest in mortgage-backed securities and related derivatives on a large scale and with a highly leveraged structure. The breakdown of these shadow-banking institutions in the summer of 2007 played a major role in amplifying problems in the US real-estate and mortgage sectors and turning them into a global financial crisis.

Despite these recent experiences, arguments about the migration of activities and enforceability issues are far less convincing than the bankers and others putting them forward would like to suggest. The expansion of operations in the shadow banking system that contributed so disastrously to the crisis could easily have been avoided if regulators had used the powers that they had at their disposal. With practically no equity of their own, the shadow banking institutions involved in the recent crisis would have been unable to obtain any finance at all if it had not been for commitments made by sponsoring banks in the regulated system. These banks' guarantees enabled the unregulated shadow banks to obtain funds by issuing asset-backed commercial paper. If regulators had wanted to, they could have interfered on the grounds that the shadow banks were not really independent and therefore should not have been kept off the sponsoring banks' balance sheets, or on the grounds that, if the shadow banks were deemed to be independent, then the guarantees were in conflict with regulations limiting large exposures to individual parties. The fact that regulators saw fit not to interfere raises questions about the political economy of financial regulation in the past decade, but not about the ability of regulation in principle to prevent or limit regulatory arbitrage.

In the context of this discussion an indiscriminate reference to "the shadow banking system" is unhelpful. Institutions outside the regulated sector that operate without sponsors in the regulated part of the financial system tend to have significantly less leverage than regulated

retain earnings and to build up their equity capital reduces the value of these subsidies (a benefit to taxpayers), and in addition would provide significant social benefits. 
banks. In the crisis, many independent hedge funds had problems and quite a number of them went under, but the systemic fallout from their failures was minimal. The parts of the shadow banking system that did significantly contribute to the crisis were directly related to banks in the regulated system - and to the failure of regulators to properly deal with the institutions in their domains. $^{88}$

Given the experience that we have gone through, it is clear that a better control of the system must be the goal. The fact that "regulatory arbitrage" was more successful than it should have been must not lead us to conclude that we should avoid regulation. With such a conclusion, we would accept that we are helpless to prevent another crisis. Instead, we need to tighten both the regulations that we have and the defenses against regulatory arbitrage.

An ever-present and important challenge in capital regulation is therefore determining on an ongoing basis the appropriate set of institutions or, better, activities that should be regulated. Other challenges, such as those related to the cyclical dynamics implied by rigid equity requirements and to the way to measure capital (such as the use of accounting numbers and extent of marking to market) must also be considered carefully. In any case, regulators must be able to assess the true leverage of regulated entities, as well as their contribution to systemic, and prevent tricks from being used to hide leverage and exposures. All of this should be taken as a challenge, but not as a reason to avoid beneficial capital regulation that is focused on reducing excessive leverage.

\section{Misplaced Concerns about international competitiveness}

Another set of arguments often made in this debate and which not directly related to the merit of high equity requirements concern competition when requirements are not fully harmonized and might be uneven across countries. Bankers warn that higher equity capital requirements in one country will induce that country's financial institutions to lose out in global financial competition against the institutions of other countries that have lower equity capital requirements.

This so-called "level playing field" argument, while popular and politically effective, is very problematic. First, there are many financial products and many financial markets, and there is competition in each one of them. Any talk about failure and success in global financial competition is meaningless unless one is clear about the markets that one is referring to. For example, some banks do very well in serving certain retail markets, for loans and deposits, where they have hardly any competitor from abroad. Some markets with a truly global scope, such as

\footnotetext{
${ }^{88}$ Of course, it is also possible for hedge funds to become highly leveraged and pose systemic risk, and thus regulators should also monitor their leverage and risk, and some regulation that would prevent such systemic risk from developing might be desirable. At the very least it seems desirable to have
} 
major stock exchanges or certain derivatives markets are dominated by just a few major institutions, which moreover tend to be located in an even smaller number of jurisdictions.

Second, the implicit identification of national interests with the competitive successes of the country's financial institutions is unwarranted. For the Irish taxpayer, for instance, it would have been much better if Irish financial institutions had been less successful in the markets for funds and in the markets for providing loans for Irish real estate developments. For the German taxpayer, it would have been much better if the shadow banks of the German Landesbanken had been less successful in acquiring asset-backed securities and issuing asset-backed commercial paper. For the Swiss taxpayer, it would have been much better if UBS Investment Bank had been less successful in acquiring a significant share of the market for re-securitizing low-grade subprime mortgage-backed securities.

In all these examples, the erstwhile competitive successes of financial institutions ended up imposing large burdens on taxpayers. Competitive successes that are supported by public subsidies usually lower a country's welfare. Firms in the subsidized sector - and the managers of these firms - benefit, but the resources that these firms command by virtue of the subsidies could be put to better uses elsewhere. From theory and policy analysis in the area of international trade, it is well known that, if the "competitiveness" of a sector in international markets is due to government subsidies, the costs of this "competitiveness" to the taxpayer usually exceed the benefits to the firms that receive them. This assessment is just as valid for international trade involving financial services and capital movements as for trade in goods and other kinds of services. Wouldn't the economies of the United States and Germany be better off if, over the past decade, more of the newly available funds had been invested in lending to small businesses rather than in lending to subprime-mortgage borrowers? Wouldn't our economies be better off if some of the highly educated and talented people who have gone into banking over the past two decades had instead gone into other productive and innovative activities? ${ }^{89}$

The answers to the above questions are not clear. The idea of having a market economy is to let firms compete for funds and other resources on the basis of the economic value they can add. The market itself helps the economy find out how to best use its scarce resources. For this process to work well, however, it must not be distorted by unwarranted public subsidies. Given the role that subsidies from bail-outs and implicit guarantees paid for by taxpayers have played and continue to play in the financial sector, there is a prima facie presumption that our societies

\footnotetext{
${ }^{89}$ Underlying the argument here is the classic theory of international trade. As was first observed by Ricardo, an economy cannot be internationally successful in competition in all sectors at the same time. Because international exchange, like any other exchange, is based on the notion of a quid pro quo, the country whose firms are successful in the market for the "quid" is necessarily unsuccessful in the market for the "quo." To be sure, these markets are served by different firms, but these firms are connected by their reliance on domestic input markets. The firm that has a comparative advantage in international trade uses its advantage to bid input prices up; this hurts the competitiveness of the other firm, In this context, the question whether physicists are better employed in banks or in engineering is directly relevant.
} 
may be devoting excessive resources to institutions in this sector and to the "competitive successes" of these institutions. Higher equity capital requirements would reduce the need for such subsidies. If this means that financial institutions lose out on certain kinds of competition through the loss of unwarranted public subsidies, such "failures" may be very much in the national interest.

\section{Final remarks}

Banking institutions clearly serve an important function in the economy by providing credit and creating liquid deposits. As we have argued, high leverage is not required for them to be able to perform these socially valuable functions. If one believes that certain activities performed by banks and financial institutions need to be subsidized because the free market does not lead to the best outcome, then subsidies should not be given through a system that encourages excessive and dangerous leverage and risk taking and which effectively penalizes equity finance.

The main message we would like to deliver to regulators is that they should not be overly concerned with threats that a substantial increase in equity requirements will have significant negative effects on the economy and growth. Once regulators accept our assessment that, at least starting from the current situation, bank equity is not expensive, capital regulation can become an effective, powerful and flexible tool for maintaining the health and stability of the financial system. The challenges associated with this regulation can be met. As they typically do, financial markets will likely adjust quickly to a new and better system with no substantial adverse effects, and the overall impact will be to enhance the health and improve the ability of the financial sector to serve a useful role in the broader economy.

We have based our analysis of the costs and benefits of increasing equity requirements for banks on what we assess to be the fundamental economic issues involved. We expect that some will disagree with our conclusions. Any discussion of this important topic in public policy should be fully focused on social costs and benefits. Moreover, any assertions that are made should be based on sound arguments and persuasive evidence. Unfortunately, the level of policy debate on this subject that we have seen is not always consistent with these standards. 
Table 2: Summary of Reasons and Critiques

\begin{tabular}{|c|c|c|c|c|}
\hline $\begin{array}{l}\text { "Reasons" given for why increased } \\
\text { equity capital requirements would be } \\
\text { costly }\end{array}$ & Is the statement true? & $\begin{array}{l}\text { Would this “reason" } \\
\text { give incentives to bank } \\
\text { managers to object to } \\
\text { increased capital } \\
\text { requirements? }\end{array}$ & $\begin{array}{l}\text { Would this "reason" give } \\
\text { incentives to bank } \\
\text { shareholders to object to } \\
\text { increased capital } \\
\text { requirements? }\end{array}$ & $\begin{array}{c}\text { From a public policy perspective, is this a } \\
\text { legitimate reason for not significantly } \\
\text { increasing capital requirements? }\end{array}$ \\
\hline $\begin{array}{l}\text { Increased equity requirements would } \\
\text { prevent banks from operating at the } \\
\text { optimal scale. }\end{array}$ & $\begin{array}{l}\text { No. Equity can be added to } \\
\text { the balance sheet without } \\
\text { changing the bank's core } \\
\text { business. }\end{array}$ & $\begin{array}{l}\text { It should not, because it is } \\
\text { false. }\end{array}$ & $\begin{array}{l}\text { It should not, because it is } \\
\text { false. }\end{array}$ & No! It is false. \\
\hline $\begin{array}{l}\text { Increased equity requirements reduce the } \\
\text { average ROE (Return on Equity) for } \\
\text { banks. }\end{array}$ & Generally Yes. & $\begin{array}{l}\text { Yes if compensation } \\
\text { depends on ROE. }\end{array}$ & $\begin{array}{l}\text { It should not, because risk } \\
\text { is reduced and the value of } \\
\text { equity would not change. }\end{array}$ & No! This is irrelevant to value creation. \\
\hline $\begin{array}{l}\text { Increased equity requirements would } \\
\text { increase banks’ total funding costs, } \\
\text { because banks would be forced to use } \\
\text { more equity, which has a higher required } \\
\text { rate of return. }\end{array}$ & $\begin{array}{l}\text { No. Changing the capital } \\
\text { structure changes how risk } \\
\text { is distributed but not the } \\
\text { overall cost of funding. }\end{array}$ & $\begin{array}{l}\text { It should not, because it is } \\
\text { false. }\end{array}$ & $\begin{array}{l}\text { It should not, because it is } \\
\text { false. }\end{array}$ & No! It is false! \\
\hline $\begin{array}{l}\text { Increased equity requirements would } \\
\text { decrease the size of the interest tax shields } \\
\text { banks can obtain through debt financing. }\end{array}$ & Yes. & $\begin{array}{l}\text { Perhaps, but this depends } \\
\text { on their compensation } \\
\text { and preferences. }\end{array}$ & $\begin{array}{l}\text { Yes, because shareholders } \\
\text { benefit from subsidies. }\end{array}$ & $\begin{array}{l}\text { No! Tax shields subsidize the use of debt, } \\
\text { but it makes no sense to encourage leverage } \\
\text { since it generates negative externalities and } \\
\text { distortions. }\end{array}$ \\
\hline $\begin{array}{c}\text { Increased equity requirements reduce } \\
\text { banks' ability to use cheap debt financing } \\
\text { that is subsidized by implicit government } \\
\text { guarantees. }\end{array}$ & Yes. & $\begin{array}{l}\text { Yes if compensation is } \\
\text { related to equity value. }\end{array}$ & $\begin{array}{l}\text { Yes, because shareholders } \\
\text { benefit from subsidies. }\end{array}$ & $\begin{array}{c}\text { No! Guarantees subsidize the use of debt, } \\
\text { but it makes no sense to encourage leverage } \\
\text { since it generates negative externalities and } \\
\text { distortions. }\end{array}$ \\
\hline $\begin{array}{l}\text { Increased equity requirements would } \\
\text { reduce managerial discipline and thus } \\
\text { interfere with effective governance. }\end{array}$ & Very unlikely to be true. & No. & $\begin{array}{l}\text { It should not, because } \\
\text { there are alternative ways } \\
\text { to create effective } \\
\text { governance. }\end{array}$ & $\begin{array}{l}\text { No! Claims that debt disciplines managers } \\
\text { are not supported by adequate theories or by } \\
\text { empirical evidence. }\end{array}$ \\
\hline $\begin{array}{l}\text { Increased equity requirements would lead } \\
\text { banks to restrict lending if they perceive } \\
\text { their equity to be under-valued. }\end{array}$ & Possibly true. & Perhaps. & Perhaps. & $\begin{array}{l}\text { No! Better capitalized banks have more } \\
\text { retained earnings for lending; any negative } \\
\text { impact of equity issuance or payout } \\
\text { restrictions can be mitigated by reducing } \\
\text { banks' discretion. }\end{array}$ \\
\hline
\end{tabular}




\section{References}

1) Acharya, Viral V., Irvind Gujral, and Hyun Song Shin (2009), "Dividends and Bank Capital in the Financial Crisis of 2007-2009,” Working paper.

2) Acharya, Viral, V. and Matthew Richardson (2009), "How Securitization Concentrated Risk in the Financial Sector," Critical Review, Special Issue on the Financial Crisis.

3) Acharya, Viral V., Philipp Schnabl, and Gustavo Suarez (2010) "Securitization without Risk Transfer,” Working paper.

4) Acharya, Viral V., Hamid Mehran, and Anjan Thakor (2010) "Caught between Scylla and Charybdis? Regulating Bank Leverage when there is Rent Seeking and Risk Shifting," Working paper.

5) Ackermann, Josef (2010), “The New Architecture of Financial Regulation: Will it Prevent Another Crisis?” Working paper.

6) Admati, Anat R. and Paul Pfleiderer (2010), "Increased Liability Equity: A Proposal to Improve Capital Regulation of Large Financial Institutions,” working paper.

7) Adrian, Tobias and Hyun Song Shin (2010), “Liquidity and Leverage,” Journal of Financial Intermediation, 19, 418-437.

8) Adrian, Tobias and Markus K. Brunnermeier (2009), “CoVaR.” Federal Reserve Bank of New York Staff Report 348.

9) Akerlof, George A. (1970), “The Market for "Lemons": Quality Uncertainty and the Market Mechanism,” Quarterly Journal of Economics, 488-500.

10) Akerlof, George A. and Paul M. Romer, (1993), "Looting: The Economic Underworld of Bankruptcy for Profit,” Brookings Papers on Economic Activity. 1-73.

11) Alessandri, Piergiorgio and Andrew G. Haldane, (2009), "Banking on the State,” Presented at the Federal Reserve Bank of Chicago $12^{\text {th }}$ Annual International Banking Conference, September 25, 2009.

12) Ang, Andrew, Sergey Gorovyy and Gregory B. van Inwegen (2011), "Hedge Fund Leverage,” NBER working paper 16801.

13) Angelini, Paolo et. al (2011), "Basel III: Long Term Impact on Economic Performance and Fluctuation,” Federal Reserve Bank of New York, Staff Report 485.

14) Angeletos, George-Marios, and Iván Werning (2006), "Crises and Prices: Information Aggregation, Multiplicity, and Volatility,” American Economic Review 96, 1720-1736.

15) Bank of Canada (2010), "Strengthening International Capital and Liquidity Standards: A Macroeconomic Impact Assessment for Canada."

16) Banyi, Monica, Susan Porter, and Susan Williams (2010), "Stock Repurchases and TARP in the Banking Industry,” Working paper.

17) Basel Committee on Banking Supervision (BIS, 2009), "Strengthening the Resilience of the Banking Sector.” 
18) Basel Committee on Banking Supervision (BIS, 2010a), "An Assessment of the LongTerm Economic Impact of Stronger Capital and Liquidity Requirements.”

19) Basel Committee on Banking Supervision (BIS, 2010b), "The Basel Committee's Response to the Financial Crisis: Report to the G20.”

20) Basel Committee on Banking Supervision (BIS, 2010b), "Proposal to ensure the loss absorbency of regulatory capital at the point of non-viability - consultative document."

21) Bhagat, Sanjai and Brian Bolton (2010), "Bank Executive Compensation And Capital Requirements Reform,” Working paper.

22) Bebchuk, Lucian A., Alma Cohen, and Holger Spamann (2010), "The Wages of Failure: Executive Compensation at Bear Stearns and Lehman 2000-2008," Yale Journal of Regulation, 27, 257-282.

23) Bebchuk, Lucian A. and Holger Spamann (2010), “The Wages of Failure: Executive Compensation at Bear Stearns and Lehman 2000-2008,” Yale Journal of Regulation, 27, 257-282.

24) Berger, Allen N., Richard J. Herring, and Giorgio P. Szegö (1995), “The Role of Capital in Financial Institution,” Journal of Banking and Finance, 19, 393-430.

25) Berger, Allen N., and Christa H.S. Bouwman (2010), "Bank Capital, Survival, and Performance around Financial Crises,” working paper.

26) Berk, Jonathan and Peter M. DeMarzo (2008), “Corporate Finance,” Prentice Hall.

27) Bhagat, Sanjai and Brian Bolton (2010), “Investment Bankers’ Culture of Ownership?” Working paper.

28) Bizer, David and Peter M. DeMarzo (1992), “Sequential Banking,” Journal of Political Economy 100, 41-61.

29) Bolton, Patrick and Xavier Freixas (2006), "Corporate Finance and the Monetary Transmission Mechanism,” Review of Financial Studies, 19, 829-870.

30) Bolton, Patrick, Tano Santos and Jose Scheinkman (2010), “Outside and Inside Liquidity,” Quarterly Journal of Economics, forthcoming.

31) Bolton, Patrick, Hamid Mehran and Joel Shapiro (2010), "Executive Compensation and Risk Taking,” working paper.

32) Boot, Arnoud W.A. (1996), "Comments on "Market Structure, Monitoring and Capital Adequacy Regulation” by Thomas Gehrig”, Swiss Journal of Economics and Statistics, 132, 703-706

33) Boot, Arnoud W.A. and Anjolein Schmeits (1998), "Challenges to competitive banking: a theoretical perspective,” Research in Economics (1998) 52, 255-270.

34) Boskin, Michael J. (2010), “Time to Junk the Corporate Tax,” The Wall Street Journal, May 6, 2010.

35) Brealey, Richard A., Stewart C. Myers, and Franklin Allen (2007), "Principles of Corporate Finance," 9th Edition, McGraw-Hill Irwin. 
36) Brealey, Richard A. (2006), "Basel II: The Route Ahead or Col-de-sac?," Journal of Applied Corporate Finance, 4, 34-43.

37) Brunnermeier, Markus and Martin Ohemke, (2010), “The Maturity Rat Race,” Working paper.

38) Calomiris, Charles W. (1999), "Building an Incentive Compatible Safety Net," Journal of Banking \& Finance, 23, 1499-1519.

39) Calomiris, Charles W. and Gary Gorton (1991), “The Origins of Banking Panics,” in: G. Hubbard (ed.), Financial Markets and Financial Crises, University of Chicago Press, Chicago, 109-173

40) Calomiris, Charles W. and Charles M. Kahn (1991), "The Role of Demandable Debt in Structuring Optimal Banking Arrangements,” American Economic Review, 81, 497-513.

41) Carbo-Valverde, Santiego, Edward J. Kane, and Francisco Rodriguez-Frenandez (2011), "Safety-Net Benefit Conferred on Difficult-to-Fail-and-Unwind Banks in the US and EU Before and During the Great Recession,” Working paper.

42) Chari, Varadarajan V., and Ravi Jagannathan (1988), "Banking Panics, Information, and Rational Expectations Equilibrium,” Journal of Finance 43, 749-760.

43) Cheng, Ing-Haw and Konstantin Milbradt (2010), “The Hazards of Debt: Rollover Freezes, Incentives, and Bailouts,” Working paper

44) Dewatripont M, and Jean Tirole (1994), "A Theory of Debt and Equity: Diversity of Securities and Manager-Share-holder Congruence," Quarterly Journal of Economics, 109, 1027-1054.

45) Diamond, Douglas W., and Phillip H. Dybvig (1983), "Bank Runs, Deposit Insurance, and Liquidity,” Journal of Political Economy 91, 401-419.

46) Diamond, Douglas W., (1984) "Financial Intermediation and Delegated Monitoring," Review of Economic Studies 51, 193-414.

47) Diamond, Douglas W., and Raghuram G. Rajan (2000), “A Theory of Bank Capital,” Journal of Finance, 55, 2431-2465.

48) Diamond, Douglas W., and Raghuram G. Rajan (2001), "Liquidity Risk, Liquidity Creation and Financial Fragility,” Journal of Political Economy 109, 287-327.

49) DeMarzo, Peter M. (1988), “An Extension of the Modigliani-Miller Theorem to Stochastic Economies with Incomplete Markets and Interdependent Securities,” Journal of Economic Theory, 353-369.

50) DeMarzo, Peter M. and Darrell Duffie (1999), "A Liquidity-Based Model of Security Design,” Econometrica, 65-99.

51) DeMarzo, Peter M, Ilan Kremer and Andrzej Skrzypacz (2005), "Bidding with Securities: Auctions and Security Design,” American Economic Review, 936-959.

52) Duffie, Darrell (2010), "How Big Banks Fail and What to Do About It," Princeton University Press, forthcoming. 
53) Elliott, Douglas J. (2009), “Bank Capital and the Stress Tests,” Working paper.

54) Flannery, Mark J. (2005), "No Pain, No Gain? Effecting Market Discipline via Reverse Convertible Debentures," Chapter 5 of Hall S. Scott, ed. Capital Adequacy Beyond Basel: Banking Securities and Insurance, Oxford: Oxford University Press.

55) French, Kenneth R., et al. (2010), “The Squam Lake Report: Fixing the Financial System,” Princeton University Press, Princeton, NJ.

56) Gale, Douglas M. and Martin F. Hellwig (1985), "Incentive-Compatible Debt Contracts: The One-Period Problem,” Review of Economic Studies 52, 647-663.

57) Gandhi, Priyank, and Hanno Lustig (2010), "Size Anomalies in U.S. Bank Stock Returns: A Fiscal Explanation,” Working paper.

58) Geanakoplos, John (2010), "Solving the Present Crisis and Managing the Leverage Cycle," FRBNY Economics Policy Review, 101-131.

59) Goldstein, Itay, and Ady Pauzner (2005), "Demand-Deposit Contracts and the Probability of Bank Runs,” Journal of Finance 60, 1293-1327.

60) Gorton, Gary B (2010), Slapped by the Invisible Hand: The Panic of 2007, Oxford University Press.

61) Gorton, Gary B. and George Pennacchi (1990), "Financial Intermediation and Liquidity Creating,” Journal of Finance, 49-71.

62) Gorton, Gary B. and Andrew Metrick (2009), "Securitized banking and the run on repo,” NBER Working Paper No. 15223.

63) Goodhart, Charles (2010a), “How Should We Regulate the Financial Sector?” Chapter 5 of The Future of Finance, LSE.

64) Goodhart, Charles, M. U. Peiris, D.P. Tsomocos, and A. P. Vardoulakis (2010), "On Dividend Restrictions and the Collapse of the Interbank Market," Annals of Finance, February.

65) Graham, John R., and Campbell Harvey (2002), "How do CFOs Make Capital Budgeting and Capital Structure Decisions,” Journal of Applied Corporate Finance, Spring, pp. 8-23.

66) Grossman, Sanford J., and Oliver D. Hart (1980), "Takeover Bids, the Free-Rider Problem, and the Theory of the Corporation,” Bell Journal of Economics 11, 42-64.

67) Haldane, Andrew, G. (2010), "Regulation or Prohibition: The $\$ 100$ billion Question," Journal of Regulation and Risk North Asia, 101-122.

68) Haldane, Andrew, Simon Brennan and Vasileios Madouros (2010), "What is the Contribution of the Financial Sector: Miracle or Mirage?” Chapter 2 of The Future of Finance, LSE.

69) Hanson, Samuel, Anil K. Kashyap, and Jeremy C. Stein (2010), “A Macroprudential Approach to Financial Regulation,” Journal of Economic Perspectives, Forthcoming.

70) Harrison, Ian (2004), “Banks, Capital and Regulation: Towards an Optimal Capital Regime for a Small Open Economy,” Working paper, Reserve Bank of New Zealand. 
71) Hart, Oliver and Luigi Zingales (2010), “A New Capital Regulation for Large Financial Institutions,” Working paper.

72) He, Zhiguo and Wei Xiong (2009), “Dynamic Debt Runs,” Working paper.

73) Hellwig, Martin F., (1981), "Bankruptcy, Limited Liability, and the Modigliani-Miller Theorem,” American Economic Review, 155-170.

74) Hellwig, Christian (2002), "Public Information, Private Information, and the Multiplicity of Equilibria in Coordination Games,” Journal of Economic Theory 107, 191-222

75) Hellwig, Martin F. (2009a), “A Reconsideration of the Jensen-Meckling Model of Outside Finance,” Journal of Financial Intermediation 18, 495-525.

76) Hellwig, Martin F. (2009b), "Systemic Risk in the Financial Sector: An Analysis of the Subprime-Mortgage Financial Crisis,” De Economist, 157, pp 129-207

77) Hellwig, Martin F. (2010), “Capital Regulation: Business as Usual?” Working paper.

78) Holmström, Bengt, and Jean Tirole (1993), "Market Liquidity and Performance Monitoring,” Journal of Political Economy 101, 678-709.

79) Holtfrerich, Carl-Ludwig (1981): "Die Eigenkapitalausstattung deutscher Kreditinstitute 1871-1945,” Bankhistorisches Archiv, Beiheft 5, 15-29.

80) Institute of International Finance (IIF, 2010) "Interim Report on the Cumulative Impact on the Global Economy of Proposed Changes in the Banking Regulatory Framework.”

81) Jacklin, Charles J., and Sudipto Bhattacharya (1988), "Distinguishing Panics and Information-Based Bank Runs: Welfare and Policy Implications,” Journal of Political Economy 96, 568-592.

82) Jensen, Michael C. (1986), "Agency Costs of Free Cash Flow, Corporate Finance and Takeovers,” American Economic Review, Papers and Proceedings 76, 323-329.

83) Jensen, Michael C. (1989), "Eclipse of the Public Corporation,” Harvard Business Review, September-October 1989, 61-74.

84) Jensen, Michael C. (1993), "The Modern Industrial Revolution, Exit, and the Failure of Internal Control Systems,” Journal of Finance 48, 831-880.

85) Jensen, Michael C. and William H. Meckling (1976), "Theory of the Firm: Managerial Behavior, Agency Costs and Capital Structure,” Journal of Financial Economics 3, 305360 .

86) Johnson, Simon and James Kwak (2010), “13 Bankers,” Pantheon, NY.

87) Kane, Edward J. (1989), “The S \& L Insurance Mass, How Did It Happen?” Urban Institute Press, Washington.

88) Kane, Edward J. (2010), "Missing Elements in US Financial Reform: The Grievous Inadequacy of the Dodd-Frank Act,” Working paper.

89) Kashyap, Anil K., Raghuram G. Rajan, and Jeremy C. Stein (2008), "Rethinking Capital Regulation,” September 2008, Federal Reserve Bank of Kansas City Symposium. 
90) Kashyap, Anil K., Jeremy C. Stein, and Samuel Hanson (2010), “An Analysis of the Impact of "Substantially Heightened" Capital Requirements on Large Financial Institutions," Working Paper.

91) King, Mervyn (1990),’'International Harmonisation of the Regulation of Capital Markets: An Introduction,” European Economic Review, 34, 569-577.

92) Krishnamurthy, Arvind, Stefan Nagel and Dmitri Orlov (2011), "Sizing up Repo,” Working paper.

93) Mankiw, Gregory N., Matthew C. Weinzierl, and Danny Yagan (2009), “Optimal Taxation in Theory and Practice,” Harvard Business School Working paper.

94) Mehran, Hamid and Anjan Thakor (2010, "Bank Capital and Value in the Cross Section," Review of Financial Studies, forthcoming.

95) Kotlikoff, Laurence J. (2010), “Jimmy Stuart is Dead: Ending the World's Financial Plague Before it Strikes Again,” John Wiley \& Sons, Inc.

96) Malysheva, Nadezhda and John R. Walter (2010), "How Large Has the Federal Financial Safety Net Become?” Federal Reserve of Richmond Working Paper.

97) McDonald, Robert L. (2010), “Contingent Capital with a Dual Price Trigger,” Working paper.

98) Miles, David, Jing Yang and Gilberto Marcheggiano (2011), “Optimal Bank Capital,” Bank of England Discussion Paper.

99) Miller, Merton H. (1995), “Does the M\&M Proposition Apply to Banks?” Journal of Banking and Finance, 19, 483-489.

100) Modigliani, Franco and Merton H. Miller, (1958), "The Cost of Capital, Corporation Finance, and the Theory of Investment” American Economic Review, 48, 261-297.

101) Morris, Stephen, and Hyun Song Shin (1998), "Unique Equilibrium in a Model of SelfFulfilling Currency Attacks,” American Economic Review 88, 587-597.

102) Myers, Stewart C. (1977), "Determinants of Corporate Borrowing,” Journal of Financial Economics 5, 147-175.

103) Myers, Stewart C. and Nicholas S. Majluf (1984), "Corporate Finance and Investment Decisions When Firms Have Information that Investors Do Not Have," Journal of Financial Economics 13, 187-222.

104) Myers, Stewart C. and Raghuram G. Rajan (1998), “The Paradox of Liquidity,” Quarterly Journal of Economics 113, 733-771.

105) Ooi, Joseph T. L., Seow-Eng Ong, and Lin Li (2008), "An Analysis of the Financing Decisions of REITs: The Role of Market Timing and Target Leverage,” Journal of Real Estate Finance and Economics, 40, 130-160.

106) Pennacchi, George, Theo Vermaelen and Christian C.P. Wolff (2010), “Contingent Capital: The case for COERCs,” Working paper. 
107) Pfleiderer, Paul (2010), “On the Relevancy of Modigliani and Miller to Banking: A Parable and Some Observations, working paper.

108) Poole, William, (2009), “Moral Hazard: The Long-Lasting Legacy of Bailouts,” Financial Analysts Journal, Nov/Dec, 1-7.

109) Poole, William, (2010), “Ending Moral Hazard,” Financial Analysts Journal, Nov/Dec, 1724

110) Pozsar, Zoltan, Tobias Adrian, Adam B. Ashcraft, and Haley Boeskey (2010), "Shadow Banking,” Federal Reserve Bank of New York Staff Report 458.

111) Raviv, Alon (2004), "Bank Stability and Market Discipline: Debt for Equity Swap versus Subordinated Notes," Working paper.

112) Rochet, J-C., and Xavier Vives (2004), "Coordination Failure and the Lender of the Last Resort: Was Bagehot Right After All?” Journal of the European Economic Association 2, 1116-1147.

113) Rosengren, Eric S. (2010), "Dividend Policy and Capital Retention: A Systemic 'First Response',” Speech given at "Rethinking Central Banking” Conference, Washington, D.C., October 10, 2010.

114) Ross, Stephen A., Randolph W. Westerfield, and Jeffrey Jaffe (2008), “Corporate Finance," 8th Edition, McGraw-Hill Irwin.

115) Schaefer, Stephen M. (1990), "The Regulation of Bank and Securities Firms,” European Economic Review, 34, 587-597.

116) Schnabel, Isabel (2004), “The German Twin Crisis of 1931,” Journal of Economic History, 64, 822-871.

117) Schnabel, Isabel (2009), "The Role of Liquidity and Implicit Guarantees in the German Twin Crisis of 1931,” Journal of International Money and Finance, 28, 1-25.

118) Stein, Jeremy C. (2010), “Monetary policy as financial-stability regulation,” Working Paper, Harvard University.

119) Stiglitz, Joseph E. (1969), “A Re-Examination of the Modigliani-Miller Theorem," American Economic Review 784-793.

120) Stiglitz, Joseph E. (1974), “The Irrelevance of Corporate Financial Policy,” American Economic Review 851-866.

121) Stiglitz, J. E. and A. W. Weiss (1981), "Credit Rationing in Markets with Imperfect Information,” American Economic Review 71, 393-410.

122) Sundaresan, Suresh and Zhenyu Wang (2010), "Design of Contingent Capital with Stock Price Trigger for Conversion,” Working paper.

123) Townsend, Robert M. (1979), "Optimal Contracts and Competitive Markets with Costly State Verification,” Journal of Economic Theory 21, 265-293.

124) Turner, Adair (2010), "What do Banks do? Why do Credit Booms and Busts Occur and What can Public Policy Do about it?” Chapter 1 of The Future of Finance, LSE. 
125) Van den Heuvel (2008), “The welfare cost of bank capital requirements,” Journal of Monetary Economics 55 298-320.

126) Walter, John R. and John A. Weinberg (2002), "How Large Is the Federal Financial Safety Net?” The Cato Journal, 369-393.

127) White, Lawrence J. (1991), “The S\&L Debacle: Public Policy Lessons for Bank and Thrift Regulation,” Oxford University Press, New York. 